
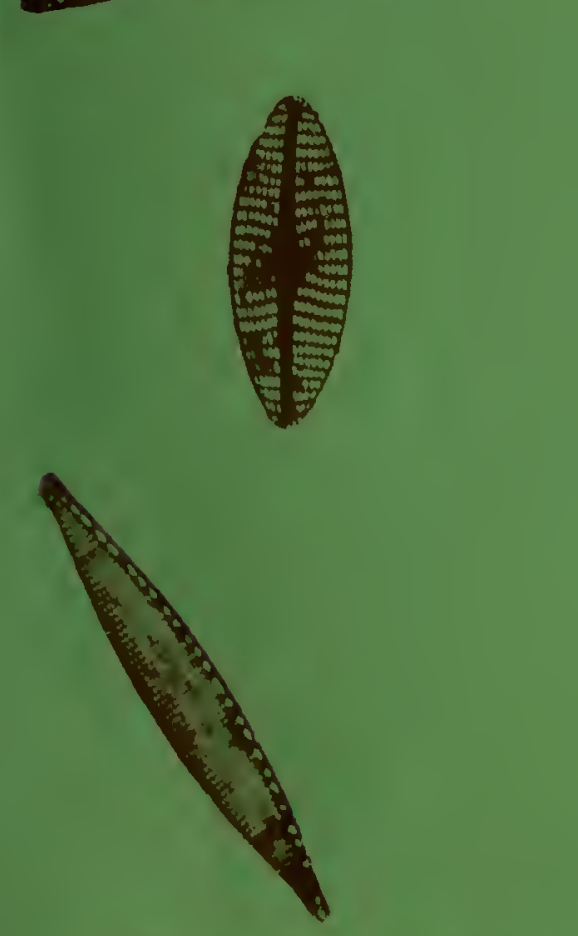

\title{
Common Diatoms
}

at

Water Pollution Surveillance

System Stations

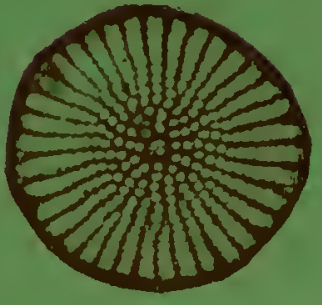

June 1966

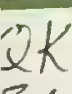

in

569

A Guide

to the

.054

$\cup 54$

1966

U.S. DEPARTMENT OF THE INTERIOR Federal Water Pollution Control Administration 

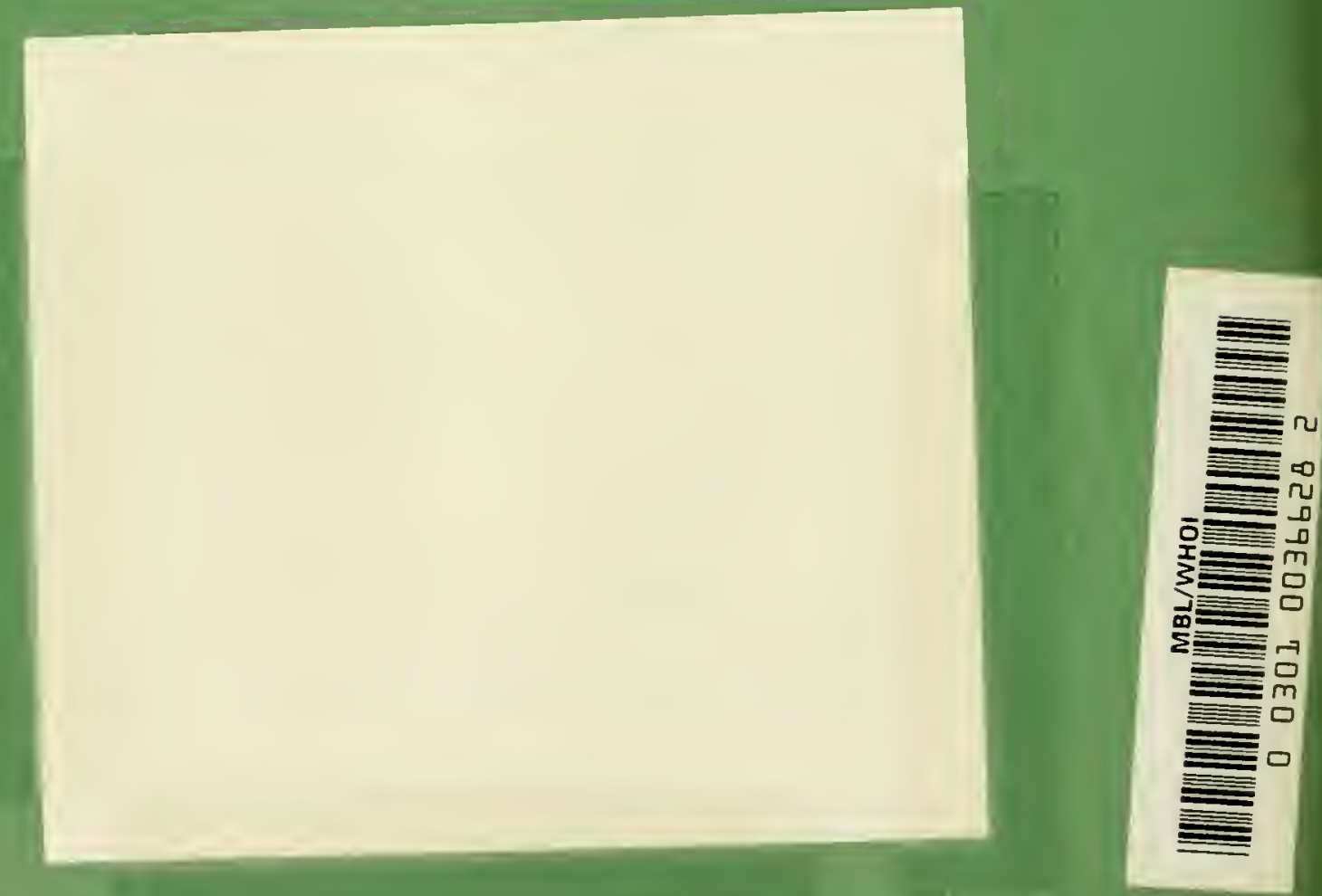
A Guide to the Common Díatoms at

Water PoIlution Surveillance System Stations

UNITED STATES DFPARTMENT OP THE INTERIOR Federal Water Pollution Control Administration Water Pollution Surveillance 1014 Broadway, Cincinnati, Ohio 45202 June 1966 
Preface

Plankton studies were initiated in 1957 under the direction of Dr. Clarence M. TaI zwell and Dr. C. Mervin Palmer. The studies which they initiated were a part of the Eublic Health Service program to collect basic data on the quality of water in major waterways. In the beginning plankton studies were limited to Sedgwick-Rafter counts of phytoplankton and zooplankton. As the phytoplankton popultions at the various stations were characterized, the dominat role of the diatoms became apparent, and preparations were begun for more intensive work with these forms. After the early species identifications were made through consultations or correspondence with Dr. Matthew Hohn, Dr. Charles Reimer, Dr. Friedrich Hustedt, and Dr. G. D. Hanna, routine diatom species identification and enumeration were inaugurated in 1959 by Dr. Louis G. Williams, who was in charge oI plankton studies from September 1958 to December 1962. Dn: Cornelius I. Weber assumed responsibility for the plankton studies in September 1963.

Mr. Louis Grivetti who was on the staff of the plankton laboratory from 1962-1964 developed the first draft of this guide to consolidate information which would be helpful to beginners in diatom identification work. The present form of this guide is the result of extensive additions and revisions by Dr. Weber and his staff.

The diatom studies have become a vital part of the plankton program. The specificity of the diatom data has rendered it especially useful in characterizing water quality.

Joseph B. Anderson

In Charge, Aquatic Biology 
CONIENIS

Page

1. Introduction......................... I

2. Collection and preparation of diatom material... 3

3. The diatom cell wall................... 4

4. Glossary............................. 6

5. Generic key........................... 9

6. Alphabetical list of genera............... 16

7. Illustrated species...................... 17

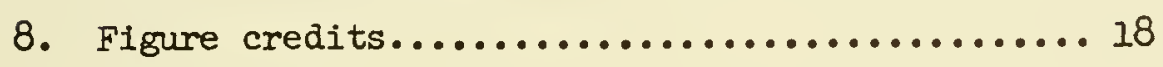

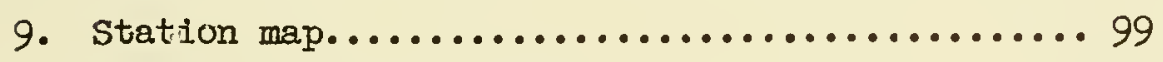

10. Diatom distribution charts....................... 



\section{Introduction}

A comprehensive treatise on the diatoms of the United States is yet to be published. Existing references dealing with the algae of this country are either very provincial or shallow in their coverage of the diatoms, therefore a large number of domestic and forelgn publications must be consulted to find descriptions of all of our common species. This is a formidable task for the beginning diatom student. Descriptions of the diatom species which are most frequently encountered at WPSS stations have been assembled in this illustrated guide which was prepared to serve as a bench reference for biologists in our laboratory who are being trained in diatom identification. The guide also contains a glossary and generic key. The key was constructed with the beginner in mind, and is based entirely on the shape and markings of the diatom cell wall as observed in material mounted in hyrax. No attempt was made to place the taxa in their proper phylogenetic order. Laboratory personnel are encouraged to consult the taxonomic references for species identification.

We are indebted to Dr. Charles Reimer, Dr. Eugene Stoermer, and Dr. Matthew Hohn for carefully reviewing the manuscript and making many helpful suggestions. We are also grateful to the various authors and publishers who have granted permission to use selected figures from their publications. 
Staff biologists who have been engaged in diatom work and have contributed to the preparation of this manual include, Carol Scott, Julia Maloney, Albert Katko, Mary Jo Sage, Louis Grivetti, Ronald Raschke, Mason Fenwick, Lydia Corrill, and Gretchen Oswald.

Cornelius I. Weber, Ph.D. In Charge, Plankton Studies 
Collection and Preparation of Diatom Material

The Water Pollution Surveillance System plankton samples used for diatom analyses are obtained from water plant intakes or directly from rivers or lakes at one hundred and thirty stations across the United States. The algae in the samples are concentrated by centrifuging twenty minutes at $1000 \times \mathrm{G}$. Several drops of plankton concentrate are placed on a \#l coverglass, the coverglass is dried cautiously to avoid splattering, and incinerated thirty minutes on a hot plate at $1000^{\circ} \mathrm{F}$. This treatment drives off most of the organic matter present, leaving only the siliceous diatom cell walls (thin-walled forms such as Rhizosolenia eriensis and Melosira crenulata may be difficult to observe). A drop of Hyrax mounting medium is placed in the center of a $75 \mathrm{~m} \times 25$ glass slide heated to approximately $200^{\circ} \mathrm{F}$. When the solvent has evaporated (the solvent-free Hyrax is hard and brittle at room temperature), the coverglass bearing the incinerated diatoms is inverted and placed on the drop of Hyrax, the slide is removed from the heat, and pressure is applied to the coverglass until the Hyrax cools and hardens (10 - 15 sec.). The finished slide is examined at 970x. 


\section{THE DIATOM CEIL WALL}

The diatom cell wall (frustule) is made of silica and consists of two overlapping halves, each composed of a more or less flat surface, the valve, to which are joined one or more hoop-like bands, the girdle and intercalary bands (see below).

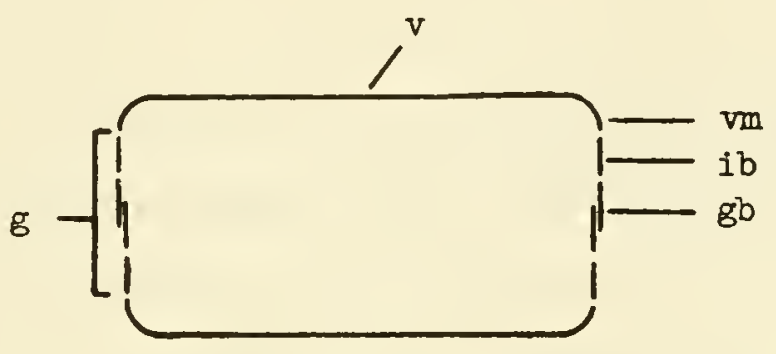

Girdle view of frustule showing valves, v; intercalary bands, ib; girdle band, gb; girdle, g; and valve mantle, ․․

The valves of the centric diatoms are generally circular in outline, with their markings arranged symetrically about a central point; whereas, the valves of the pennate diatoms are generally elongate (linear) with their markings arranged in transverse rows along each margin.

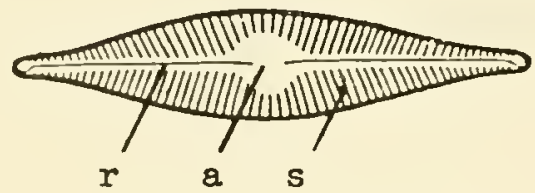

Pennate

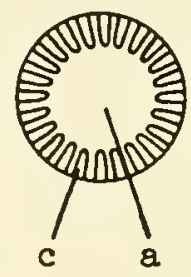

Centric

Valve views of pennate and centric diatoms showing the central area, $a$; raphe, $\underline{r}$ which usually occupies the medial axis of the valve; striae, $\underline{s}$; and costae, $\underline{c}$. 
Planes and axes of symmetry are employed in keying out some of the pennate genera. They are shown in the figures below.

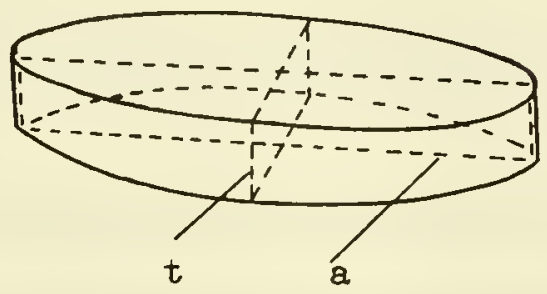

Oblique view of a pennate frustule showing planes; apical plane (along longitudinal or medial axis), a; transapical plane (along the transverse axis), $\underline{t}$.

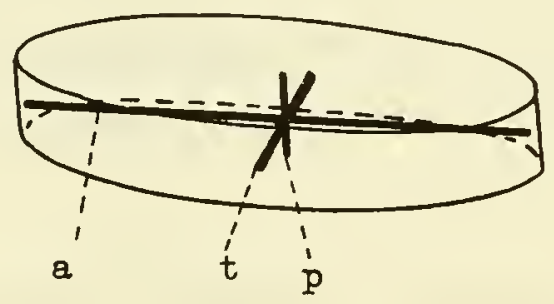

Oblique view of a pennate frustule showing axes: apical axis, a; transapical axis, $\underline{t}$; and the pervalvar axis, $\underline{p}$. 


\section{GLOSSARY}

Arcuate - bent like a bow (see Fragilaria arcus, p. 38)

Brackish - having a dissolved salt content intermediate between fresh and salt water.

Capitate - swollen at one or both ends in valve view (see Caloneis amphisbaena, p. 63)

Carinal dots - circular or oval pores more or less evenly spaced along the keel, usually appearing as dots or lines (see Nitzschia, p. 90) Costae - internal or external linear thickenings of the valve surface appearing as ribs; because of light diffraction, the tapered shoulders of the costae may appear as dark lines (see Cyclotella Meneghiniana, p. 26)

Facet - (alveola) a circular or hexagonal thin area in the valve surface, surrounded by a ridge which may extend internally or externally from the valve surface (see Coscinodiscus, p. 31)

Frustule - the siliceous diatom cell wall consisting of two separate halves.

Fusiform - broadest at the middle and tapering at each end, spindleshaped (naviculoid).

Girdle - region of the frustule between the two valves. Girdle-bands - the two overlapping hoop-like bands which join the two halves of the frustule. They may be connected directly to the valve margins or the intercalary bands.

Girdle view - side view of the frustule.

Intercalary bands - hoop-like bands located between the girdle-band and the valve (see Rhizosolenia, p. 22) 
Keel - a ridge projecting from the valve-surface, enclosing the "canal" raphe, usually not medial on the valve (see Nitzschia, p. 89) Linear - long and nearly uniform in width. Micron - 0.001 millimeter. Multiseriate - having more than one row of punctae (see Stephanodiscus astrea, p. 28)

Nodule - internal thickening of the cell wall in the central area or terminal portions (poles) of the valves of pennate diatoms. Ocellus - a raised, rounded or ovate thickening of the valve surface having the appearance of a large pore (see Cyclotella ocellata, p. 27)

Poles - extreme ends of the valves of pennate diatoms.

Pseudoraphe - a smooth, linear space between the medial ends of the striae or costae on the valves of pennate diatoms. A term applied only to valves without a true raphe (see synedra ulna, p. 45) Punctae - small holes (pores) or thin, circular, sieve-like areas in the frustule.

Raphe - a fissure or slit in the valve face which may be along or eccentric to the medial axis of the valve; when located in a keel or wing it is referred to as a "canal" raphe.

Rhomboid - a parallelogram in which the angles are oblique and the adjacent sides are unequal (see Nitzschia, p.89)

Septae - internal partitions or cross walls, usually appearing as dark lines (see Tabellaria fenestrata, p. 32)

Shadow-lines - dark "diffraction" lines which appear in the frustule wherever abrupt changes in thickness of the valve face occur (see Caloneis, p. 63) 
Sigmoid - s-shaped (see Gyrosigma, p. 67)

Stellate - star-shaped, radiating from a point.

Striae - linear markings on the frustule which are due to closely placed punctae, or to hollow chambers in the cell wall (may sometimes appear as costae).

Sulcus - annular groove between the valve mantle and girdle (see Melosira ambigua, p. 19)

Uniseriate - having one row of punctae (see Coscinodiscus, p. 3I) Valve - the face of the diatom frustule. Valve mantle - the part of the valve which extends below the shoulder. In the Melosiras the valve mantle is a cylindrical surface that may be $30 \mu$ long (see Melosira granulata, p. 20)

Wing - a thin projection of the valve surface, more highly developed than a keel; generally arising near the margin of the valve, but sometimes arising near the medial axis. May enclose the "canal" raphe (see Surirella, p. 87) 


\section{GENERIC KEY}

la Valves with true raphe or pseudoraphe; ormamentation transverse and/or longitudinal...................

Ib Valves without true raphe or pseudoraphe; ornamentation radial about a central point..

2a Frustules usually united into long filaments.......... Melosira (p. 19)

$\mathrm{2b}$ Frustules not usually united into long filaments; usually solitary but may form short chains.

3a Frustules with intercalary bands; usually seen in girdle view; one or two long spines arising from each valve....

3b Frustules without intercalary bands.

4a One long spine arising from each valve...............

\section{Rhizosolenia (p. 22)}

4b Two long spines arising from each valve.... Attheya (p. 23)

5a Valves with two marginal protuberances or horns on opposite sides of the valve; usually seen in girdle view. Biddulphia (p. 23)

$5 \mathrm{~b}$ Valves lacking protuberances....................

$6 a$ Valve margin with costae; ornamentation in central area different from margin........... Cyclotella (p. 24)

$6 \mathrm{~b}$ Valve margin otherwise; central area not sharply distinct from margin; valves with radial rows of punctae or with geometric facets........................... 
7a Punctae in multiseriate rows near valve margin, each row gradually or abruptly becoming uniseriate toward the center; marginal spines always present.............. Stephanodiscus (p.28)

To Punctae in uniseriate rows throughout, or with geometric facets.................. Coscinodiscus ( $p .31$ )

8a True raphe present on at least one valve; raphe may be very short or rudimentary, or may be concealed in a

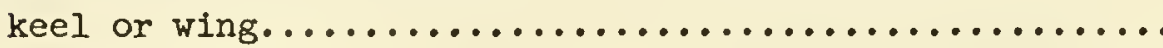

8b True raphe absent, pseudoraphe present on both valves...

9a Frustules with thick longitudinal septae running parallel to the valve faces............... Tabellaria (

$9 \mathrm{~b}$ Frustules without septae........................ 10

10a Valves with thickened internal transverse ribs (costae), most of which extend completely across the valve face... II

10b valves without thickened internal transverse ribs...... 12

lla Valves symmetrical about the transapical plane......... Diatoma (p. 33)

llb Valves asymmetrical about the transapical plane........ Meridion (p. 36)

12a Frustules with bulbous ends, slightly concave in girdle view, typically forming stellate colonies.

12b Frustules without bulbous ends, typically not forming stellate colonies........................... 
13a Valves symmetrical about the transapical plane.........

13b Valves asymmetrical about transapical plane...........

Opephora (p. 38)

14a Frustules typically forming long ribbon-like chains, rarely solitary.............. Fragilaria ( $p .38$ )

14b Frustules typically solitary, sometimes forming stellate colonies; striae often appearing as costae............ Synedra (p. 42)

15a Raphe evident on at lease one valve.............. 16

15b Raphe not evident, concealed in a keel or wing........ 35

16a Valves similarly ornamented, raphe on both valves...... 19

16b Valves not similarly ornamented, raphe on one valve, opposing valve with pseudoraphe, or with rudimentary

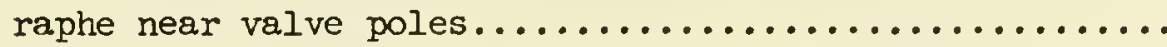

17a Valves elliptical, never linear, sometimes bent along the apical axis.................... Cocconeis (p. 47)

17b Valves not elliptical, usually linear, and usually bent along the transapical axis...................... 18

18a Valves symmetrical about the transapical plane, one valve with completely developed raphe, opposing valve with pseudoraphe.................. Achnanthes ( $p .50$ )

18b Valves asymetrical about the transapical plane, one valve with completely developed raphe, opposing valve with mudimentary raphe near valve poles.............. Rhoicosphenia (p. 52) 
19a Raphe rudimentary, short, near poles only............ Eunotia (p. 53)

19b Raphe fully developed, extending the length of the

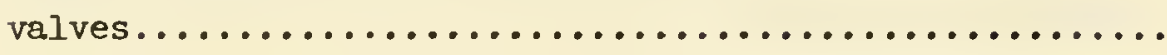

20a Valves symetrical about both the transapical and apical plane. 24

20b Valves asymetrical about either the apical or transapical plane.......................... 21

2la Valves symmetrical about the transapical plane, asymetrical about the apical plane........................ 23

21b Valves asymmetrical about the transapical plane, symmetrical about the apical plane............... 22 22a Valve margins with longitudinal "shadow"-lines......... Gomphone is (p. 54)

2२b Valve margins lacking longitudinal shadow"-lines........ Gomphonema (p. 54)

23a Valve faces parallel............. Cymbella (p. 57)

23b Valve faces not parallel, both valves faces can be seen in girdle view.................. Amphora (p. 60)

24a Valves with elongate central or terminal nodules....... 25

24b Valves without elongate central or terminal nodules.... 26

25a Central nodule drawn out to at least half the length of the valve................. Amphipleura (p. 62)

25b Central nodule drawn out less than half the length of the valve................. Frustulia (p. 62) 
26a Valves with longitudinal "shadow"-lines or blank

spaces.................................... 27

$26 \mathrm{~b}$ Valves without longitudinal lines or blank spaces...... 29

27a Transverse striae continuous, crossed by one or two

longitudinal "shadow"-lines paralleling valve margin.... Caloneis (p.63)

27b Transverse striae discontinuous, intermupted by blank spaces or "shadow"-lines.

28a Longitudinal "shadow"-lines or blank spaces near valve margins; ends of raphe near central nodule usually turned in opposite directions............. Neidium (p. 64 )

$28 \mathrm{~b}$ Longitudinal "shadow"-lines or blank spaces scattered, central pores of raphe near central nodule turned if at all in the same direction........... Anomoeoneis (p. 65)

$29 a \quad$ Valves and raphe sigmoid..................... 30

$29 \mathrm{~b} \quad$ Valves and raphe not sigmoid................... 31

30a Valves with transverse and longitudinal striae........ Gyrosigma (p. 67)

$30 \mathrm{~b}$ Valves with transverse and oblique striae............ Pleurosigma (p. 67)

3la Frustules with septae........... Mastogloia (p. 68)

3lb Frustules without septe..................... 32

32a Raphe enclosed in a siliceous rib.......... Diploneis (p. 68)

$32 \mathrm{~b} \quad$ Raphe not enclosed in a siliceous rib............. 33

33a Valves with chambered striae appearing as heavy costae; valves usually with parallel sides and broadly rounded poles. Pinnularia (p. 70) 
34a Central area extending laterally to the margins of the valve, striae absent along lateral margins of the central area................... Stauroneis $(p .70)$

34b Central area not extending to the margins of the valve, striae present along lateral margins of the central

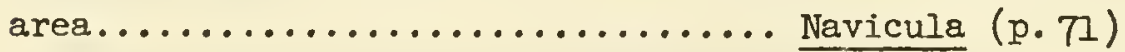

35a Keel elevated into a lateral "wing" or flattened on the valve surface.

35b Keel elevated into an axial "wing" extending along the

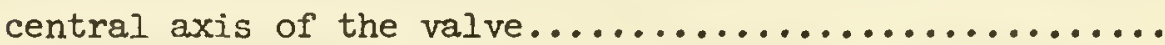

36a Keel sigmoid, usually seen in girdle view (hour-glassshaped), frustule twisted along the longitudinal axis; girdle broad with many longitudinal folds............ Amphiprora (p. 80)

36b Keel not sigmoid, girdle simple, not folded, keel eccentric.................. Tropidoneis (p. 82)

37a Valves with numerous internal transverse ribs extending completely across the valve................. 38

37b Valves without internal transverse ribs............ 40 38a Raphe and axial area with "V"-shaped medial extension; with transverse septae appearing as costae and alternat-

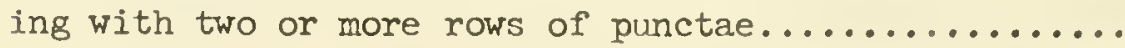
Epithemia (p. 83)

38b Raphe and axial area without a "V"-shaped medial

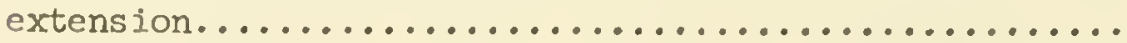


39a Raphe canal with pores, valves symmetrical to longitudinal

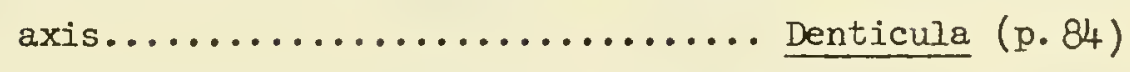

39b Raphe canal without pores, valves asymetrical to the longitudinal axis.............. Rhopalodia (p. 84)

40a Valves with lateral keel extending along both margins of

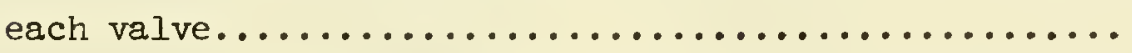

$40 \mathrm{~b}$ Valves with lateral keel extending along one margin of

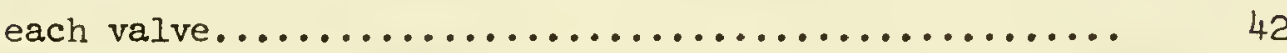

4la Valve face longitudinally undulate, undulations conspicuous in girdle view; with broad, short, peripheral costae; Iongitudinal pseudoraphe present.............. Cymatopleura (p.86)

4lb Valve face not longitudinally undulate; valve face with longitudinal folds which appear as heavy costae, folds not conspicuous in girdle view; girdle view rectangular, naviculoid, wedge shaped or sigmoid; valve view linear,

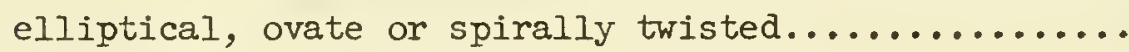

$$
\text { Surirella (p. 87) }
$$

42a Keels eccentric to the median axis, diagonally opposite; frustules rhombic in cross section, transversely striate, punctate or lacking ornamentation; a row of circular pores ("carinal dots") developed within the keel; frustules usually solitary but occasionally forming irregular ribbonlike chains or stellate colonies..... Nitzschia (p. 89) $42 \mathrm{~b}$ Keels eccentric to the median axis, directly opposite; frustules rectangular in cross section, transversely striate or punctate, capitate ends, medianly constructed... Hantzschia (p.98) 
Alphebetical list of Genera

Genus

Achnanthes

Amphipleura

Amphiprora

Amphora

Anomoeone is

Asterionella

Attheya

Biddulphia

Caloneis

Cocconeis

Coscinodiscus

Cyclotella

Cymatopleura

Cymbella

Denticula

Diatoma

Diploneis

Epithemia

Eunotia

Fragilaria

Frustulia
Page

50

62

80

60

65

37

23

23

63

47

31

24

86

57

84

33

68

83

53

38

62
Genus

Page

Gomphoneis

54

Gomphonema

54

67

Gyros Igma

Hantzschia

98

Mastogloia

68

Melosira

Meridion

36

Navicula

71

Neidium

64

Nitzschia

89

Opephora

38

Pinnularia

70

Pleurosigma

67

Rhizosolenia

22

Rhoicosphenia

52

Rhopalodia

84

Stauroneis

70

Stephanodiscus 28

Surirella

87

Synedra

42

Tabellaria

32

Tropidoneis 
Illustrated Species

A total of 164 species are illustrated, representing 43 of the common genera found at the Water Pollution Surveillance System stations. Some of the species were selected primarily to demonstrate the morphological diversity within the genera. The figures have been selected from a number of publications (p. 18) and the figure credits are referred to by number immediately following the species names. The cell dimensions given are generally those from the figure source, but in some cases these have been supplemented with our own observations. The geographical distribution of 96 of the species is shown in the accompanying chart ( $p .100)$, taken from "Plankton Population Dynamics", by L. G. Williams, PHS Pub. No. 663, Suppl. 2, 1962. Additional information regarding diatom distribution can be found in the WPSS Annual Compilations of Data, 1960-61, 1961-62, and 1962-63, PHS Pub. No. 663. 


\section{FIGURE CREDITS}

1. Boyer, Charles S., 1916. The Diatomaceae of Philadelphia and Vicinity. J. B. Lippincott Co., Philadelphia.

2. Hohn, Matthew H., and Joan Hellerman, 1963. The Taxonony and Structure of Diatom Populations From Three Eastern North American Rivers Using Three Sampling Methods. Transactions of the American Microscopical Society. 82(3):250-329.

3. Huber-Pestalozzi, G., and F. Hustedt, 1942. Die Kieselalgen. In: A.Thienemann, Das Phytoplankton des Susswassers, Die Binnengewässer, Band XVI, Teil II, Halfte II. E. Schweizerbart'sche Verlagsbuchhandlung, stuttgart.

4. Hustedt, F., 1930. Die Kiesselalgen. In: L. Rabenhorst, KryptogamenFlora von Deutschland, Osterreich, und der Schweiz, Band VII. Akademische Verlagsgesellschaft m.b.H., Leipzig.

5. Hustedt, F., 1930. Bacillariophyta. In: A. Pascher, Die SüsswasserFlora Mitteleuropas, Heft 10; Gustav Fischer, Jena.

6. Hustedt, F., 1949. Süsswasser-Diatomeen. Imprimerie M. Hayez, Bruxelles.

7. Plankton Laboratory staff, WPSS.

8. Patrick, R., 1959. The Bacillariophyceae. In: W. T. Edmondson, Fresh-water Biology, H. B. Ward and G. C. Whipple, and Edition, Wiley and Sons, N. Y.

9. Prowse, G. A., 1962. Diatoms of Malayan Freshwaters. Gardens ' Bulletin, Singapore. 19(1):1-104.

10. Smith, G., 1950. The Fresh-water Algae of the United States. 2nd Edition, McGraw-Hill Book Co., Inc., N. Y.

11. Tiffany, L. H., an M. E. Britton, 1952. The Algae of Illinois. Univ. Chicago Press, Chicago.

12. van der werff, A., and H. Huls, 1957-1961, 1963. Diatomeeenflora Van Nederland. Parts I, II, III, IV, V, VI. Stechert and Hafer, N. Y. 
la Valves with true raphe or pseudoraphe; ornamentation transverse and/or longitudinal $\ldots \ldots \ldots \ldots \ldots \ldots \ldots \ldots . . . . .6$

Ib Valves without true raphe or pseudoraphe; ornamentation radial about a central point...................... 2

2a Frustules usually united into long filaments - MELOSIRA $^{l}$

Fig. 1. Melosira ambigua, (3), valves $4-15 \mu$ in diameter, $3-13 \mu$ long; wide, angular sulcus. X 1000. Abundant in the Ohio and Mississippi Rivers.

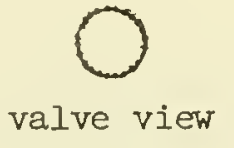

Notes:

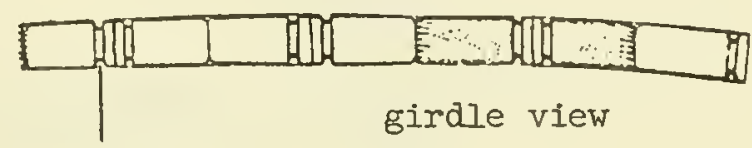

sulcus

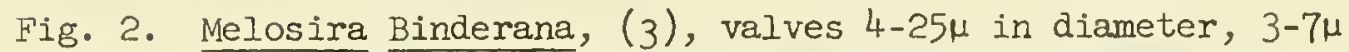
long; in valve view may be confused with Stephanodiscus Hantzschii; has distinct pores on valve mantle (shoulder). $\mathrm{X} 1000$. Common in the Great Lakes.

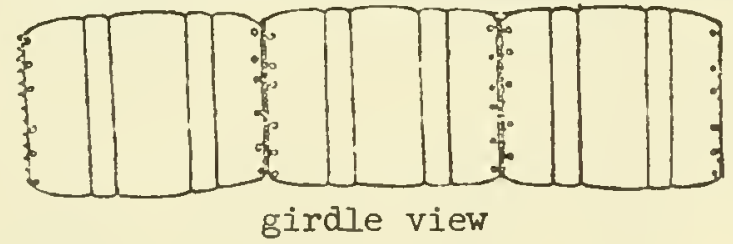

Notes:

1. Valve length in Melosira is measured from the valve face to the sulcus, along the pervalvar axis (half length).

2. This number refers to the figure source. 
Fig. 3. Melosira distans, (3), valves $4-20 \mu$ in diameter, $4-8 \mu$ long. X 1000. Abundant in southeastern rivers.

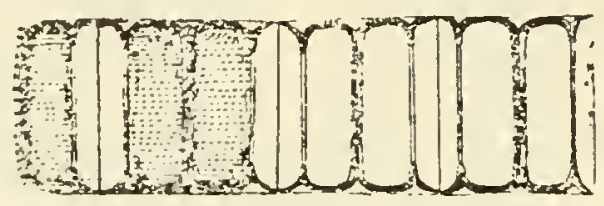

girdle view

var. Iirata,

Notes :

form lacusris

Fig. 4. Melosira granulata, (3), valves $5-21 \mu$ in diameter, 5-18 $\mu$ long; terminal cells usually with robust spines. X 1000 . Common in northern U. S.

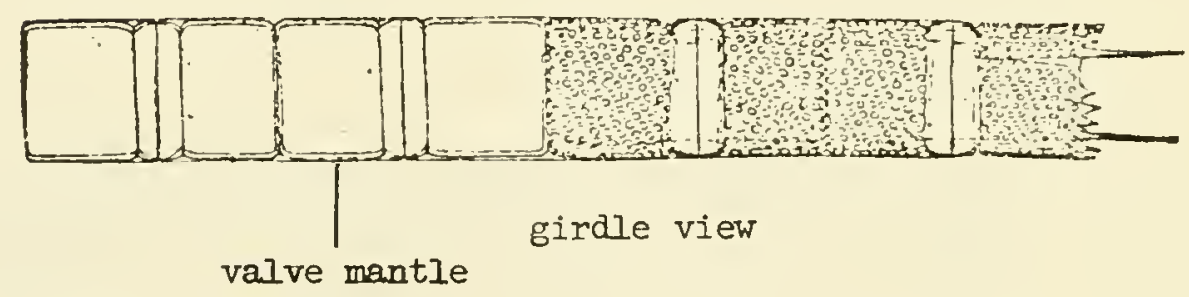

Notes:

Fig. 5. Melosira herzogii, (7), valves $4 \mu$ in diameter, $7 \mu$ long. $X \overline{2000 . ~ F o u n d ~ m o s t ~ o f ~ t e n ~ i n ~ s o u t h e a s t e r n ~ U . S . ~}$

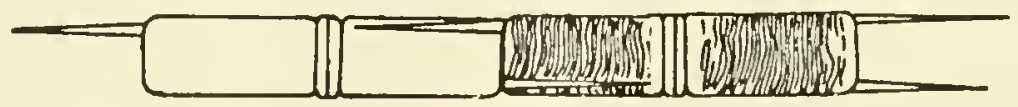

girdle view

Notes : 
Fig. 6. Melosira islandica, (3), valves $7-27 \mu$ in diameter, 4-2lu long; striae on valve mantle parallel to pervalvar axis. X 1000. Common in the Great Lakes and the Columbia River.

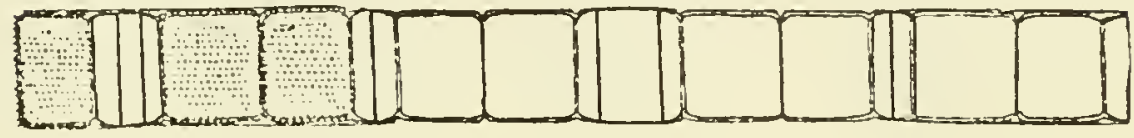

girdle view,

Notes : subsp. helvetica

Fig. 7. Melosira italica, (3), valves $5-28 \mu$ in diameter, 8-2l $\mu$ long; differentiated from $M$. ambigua by more robust spines and narrow sulcus. X 1000. Common in the Columbia River.

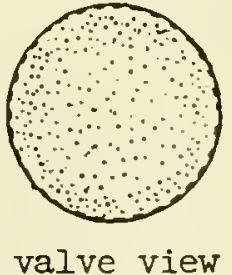

Notes:

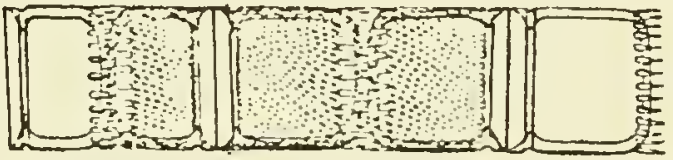

girdle view, var. valida

Fig. 8. Melosira varians, (3), valves $8-35 \mu$ in diameter, $9-13 \mu$ long; no visible ornamentation. X 1000. Widely distributed.

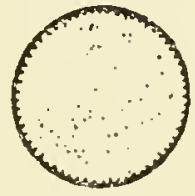

valve view

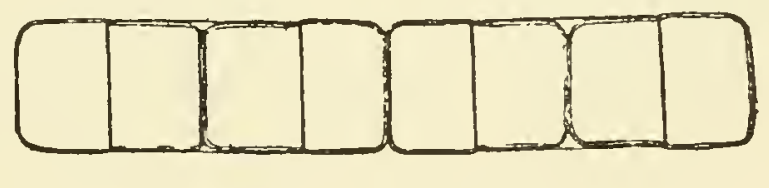

girdle view

Notes: 
Notes on other species of MELOSIRA:

2b Frustules not usually united into long filaments; usually solitary but may form short chains............. 3

3a Frustules with intercalary bands; usually seen in girdle view; one or two long spines arising from each valve......................................... 4

3b Frustules without intercalary bands................ 5

$4 a$ One long spine arising from each valve - RHIZOSOLENIA

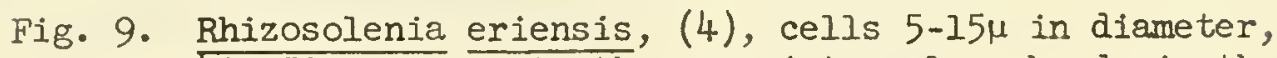
40-150 $\mu$ long; note the many intercalary bands in the girdle area. X 1000. Common in the Great Lakes.

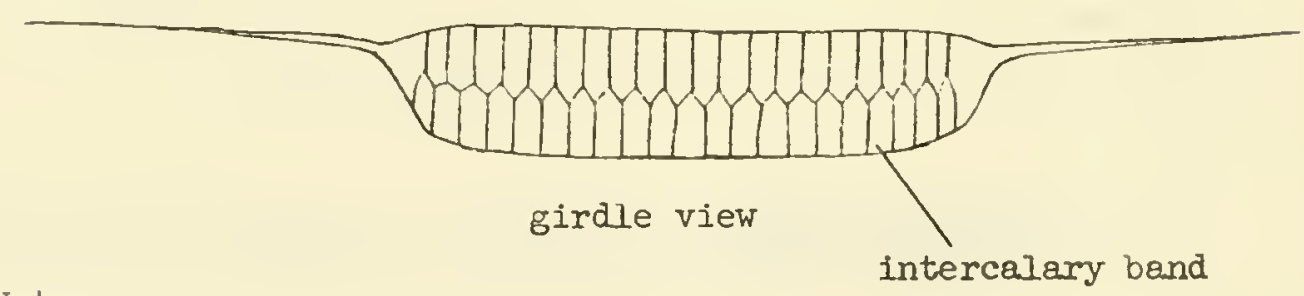

Notes : 


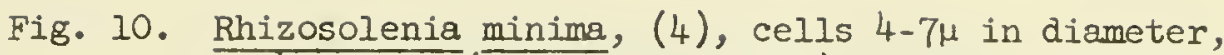
15-40 $\mu$ long (excluding spines). X 350. Southwestern U. S. (Red River).

\section{girdle view}

Notes:

4b Two long spines arising from each valve - ATTHEYA

Fig. 11. Attheya Zachariasi,(10), cells $12-40 \mu$ in diameter; spines $40-60 \mu$ long. X 500 . In Ohio and Tennessee Rivers.

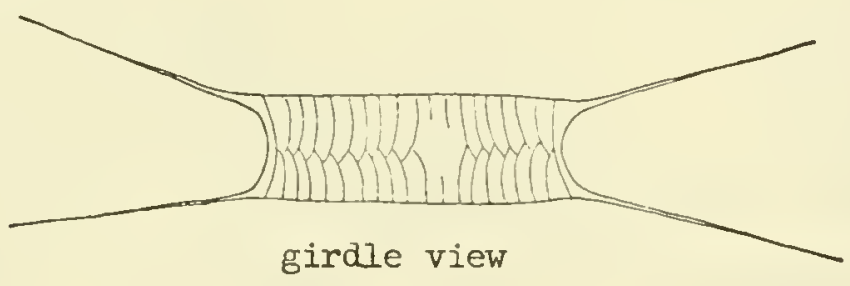

Notes :

5a Valves with two marginal protuberances or horns on opposite sides of the valve; usually seen in girdle view - BIDDULPHIA 
Fig. 12. Biddulphia laevis, (10), cells 20-150 $\mu$ in diameter, 50-1504 Iong; X 650. Southwestern U. S.

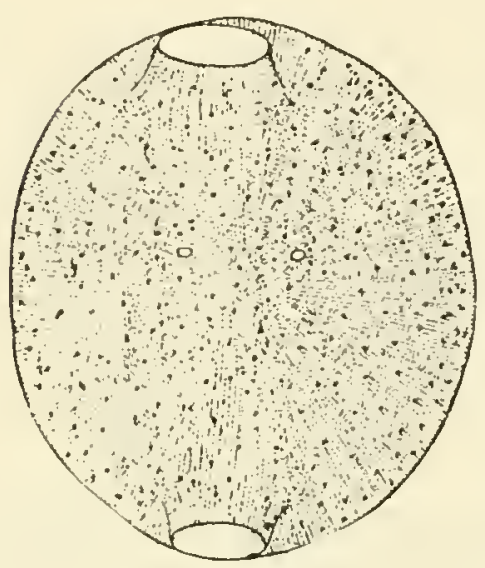

valve view

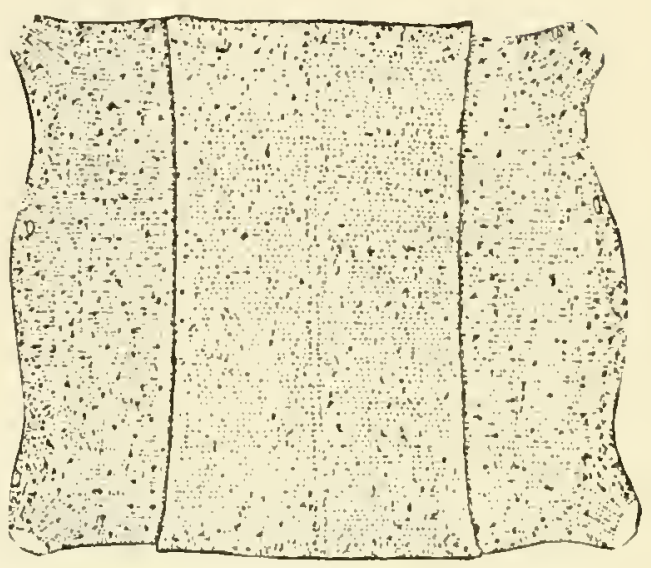

girdle view

Notes:

Valves lacking protuburances...

6a Valve margin with costae; ornamentation in central area different from margin - CYCLOTELLA

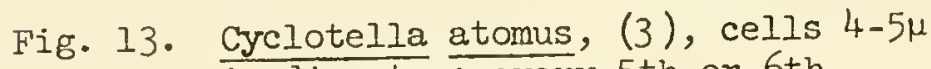

in diameter; every 5 th or 6 th costae is thicker and darker than the others; single ocellus in central area. X 1500. Widely distributed.

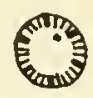

valve view

Notes :

Fig. 14. Cyclotella antiqua, (4), cells 10-30 in diameter; wedge-shaped depressions in central area. $\mathrm{X}$ 1200. In Great Lakes.

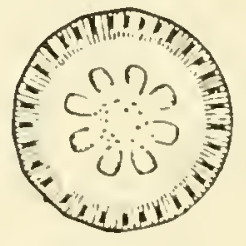

valve view 
Fig. 15. Cyclotella bodanica, (4), cells 20-80 $\mu$ in diameter; an isolated puncta occurs at the inner end of several shortened marginal costae. X 1000. In Great Lakes.

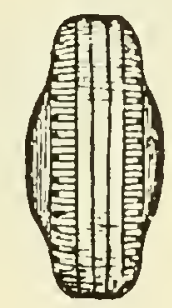

girdle view

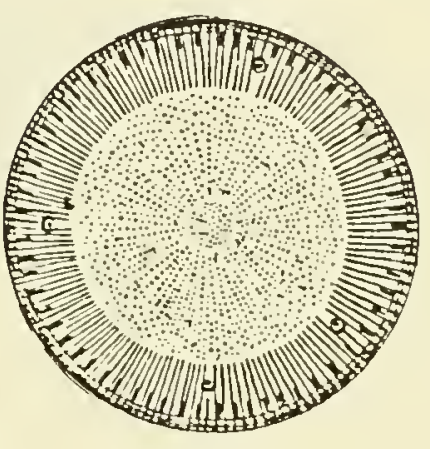

valve view

Notes :

Fig. 16. Cyclotella comta, (4), cells 15-20 in diameter; similar to c. bodanica but lacking punctae at the end of shortened costae. $\mathrm{X}$ 1000. In Great Lakes.

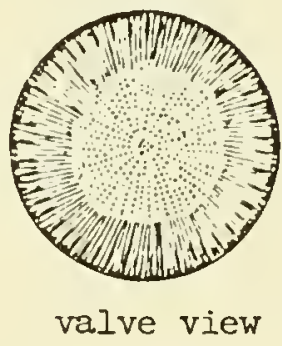

Notes :

Fig. 17. Cyclotella glomerata,(3), cells 4-10 $\mu$ in diameter; forming chains; often seen in girdle view. X 1000. In Great Lakes.

Notes:

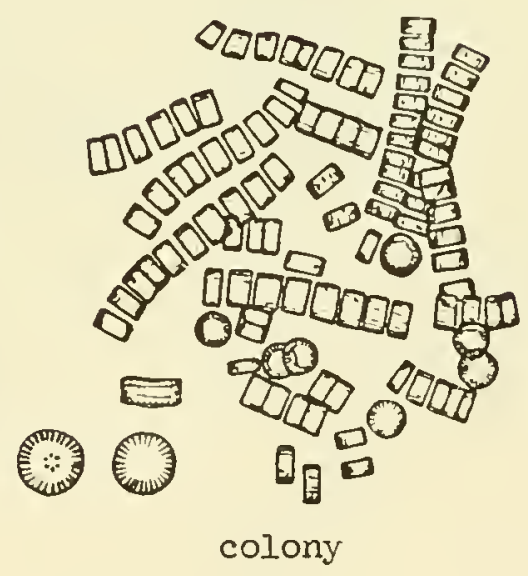


Fig. 18. Cyclotella Kutzingiana, (3), cells $10-20 \mu$ in diameter; center ornamentation highly variable. X 1000 . Common in Great Lakes.

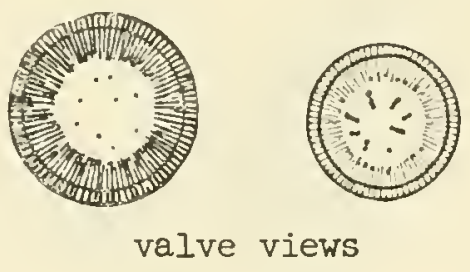

Notes:

Fig. 19. Cyclotella Meneghiniana, (12), cells $10-30 \mu$ in diameter; heavy marginal costae give impression of scalloped border. X 1000 . Widely distributed.

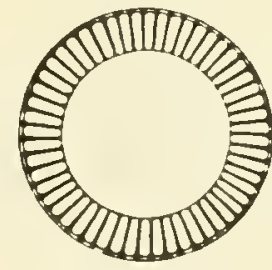

valve view

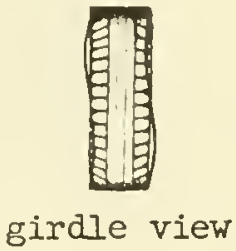

girdle view

Notes :

Fig. 20. Cyclotella michiganiana, (1]), cells $5-20 \mu$ in diameter; valve margin with pronounced rim. X 1000.
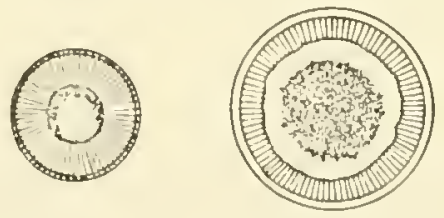

(1)

valve views

Notes : 


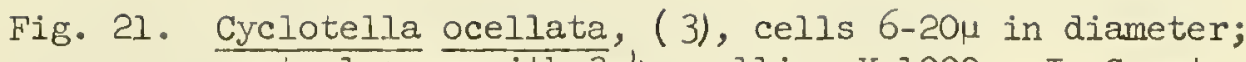
central area with 3-4 ocelli. X 1000. In Great Lakes.
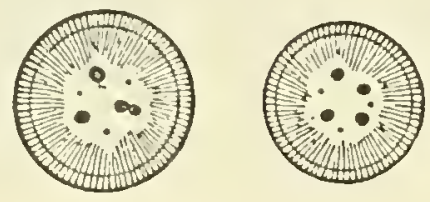

valve views

Notes:

Fig. 22. Cyclotella pseudostelligera, (7), cells $7-8 \mu$ in diameter; has marginal spines. X 3000. Widely distributed.

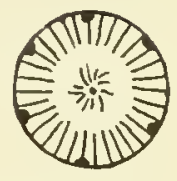

valve view

Notes:

Fig. 23. Cyclotella stelligera, (3), cells 5-25 $\mu$ in diameter. X 1000 . Abundant in the southeast.

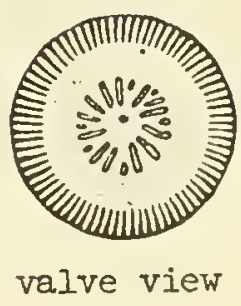

Notes : 
Fig. 24. Cyclotella striata, (4), cells 10-50 $\mu$ in diameter. Has a circular shadow line passing through the costae. $X$ 1000. In Delaware and Hudson Rivers.

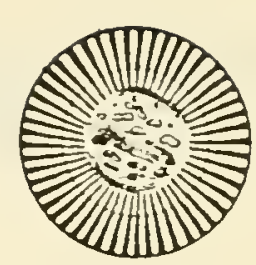

valve view

Notes:

Notes on other species of CYCLOTELIA

$6 \mathrm{~b}$ Valve margin otherwise; central area not sharply distinct from margin; valves with radial rows of punctae or with

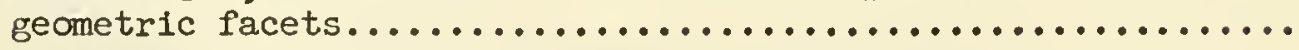

$7 a$ Punctae in multiseriate rows near valve margin, each row gradually or abruptly becoming uniseriate toward the center; marginal spines always present.- STEPHANODISCUS

Fig. 25. Stephanodiscus astrea (3), cells 10-30 $\mu$ in diameter; spines not at end of each row of punctae. Outer punctae in double to quadruple rows, 12 punctae in 10\%. X 1000 . Widely distributed.

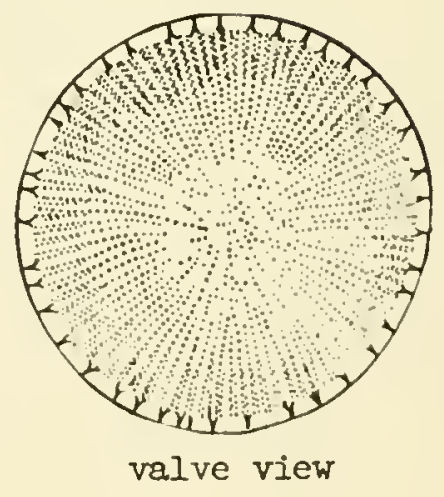

Notes: 


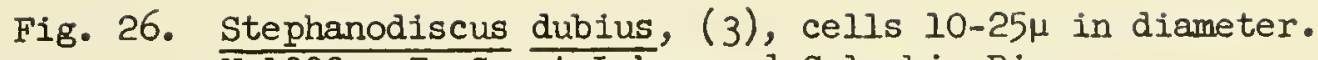
X 1000. In Great Lakes and Columbia River.

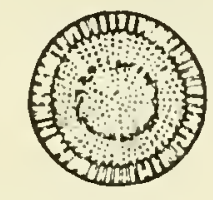

valve view

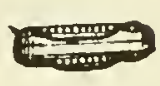

girdle view

Notes :

Fig. 27. Stephanodiscus Hantzschii, (7), striae in $10 \mu$; striae very light; frustule often collapses during incineration; may be confused with Melosira Binderana. X 2000. Widely distributed.

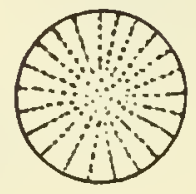

valve view

Notes :

Fig. 28. Stephanodiscus invisitatus, (7), striae in $10 \mu$; striae very light; easily confused with s. Pantzschij. X 2000. Ohio River Basin.

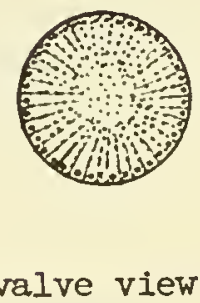

Notes : 

Fig. 29. Stephanodiscus niagarae, (3), 3-5 rows of punctae in marginal region of striae, spines submarginal and more robust than in S. astrea. X 900 . Upper Mississippi and Missouri Rivers.

Notes :

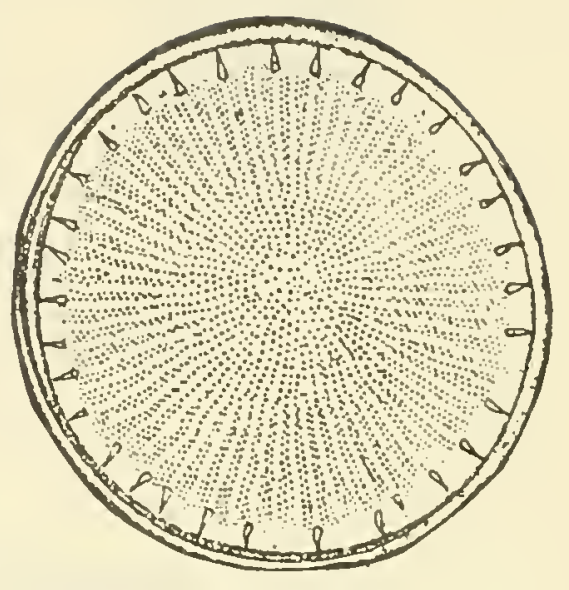

valve view

Fig. 30. Stephanodiscus tenuis, (3),

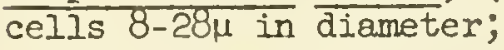

spines at end of each row

of striae. X 1000.

Notes:

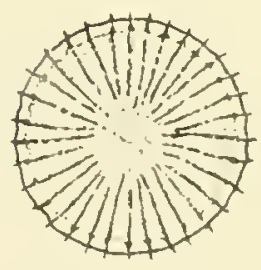

valve view

Notes on other species of STEPHANODISCUS. 
To Punctae in uniseriate rows throughout; or with geometric facets - COSCINODISCUS

Fig. 31. Coscinodiscus denarius, (4), cells $40-90 \mu$ in diameter. $\mathrm{X} 1000$.

Notes:

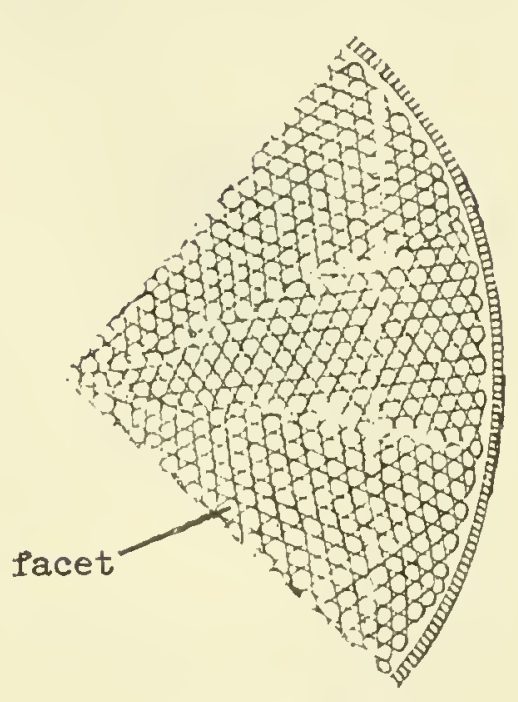

valve view

Fig. 32. Coscinodiscus lacustris, (4), cells 20-50 in diameter, with marginal spines. X 1000. Notes:

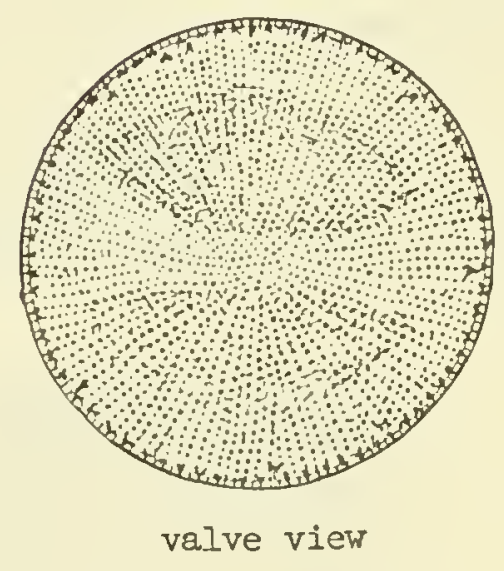

Fig. 33. Coscinodiscus Rothii, (8),

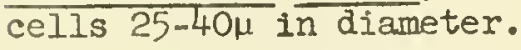
$X$ 1000. In Red and Lower Mississippi Rivers.

Notes:

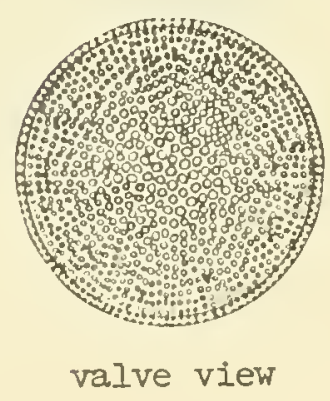


Other species of COSCINODISCUS.

8a True raphe present on at least one valve; raphe may be very short or rudimentary, or may be concealed in a keel

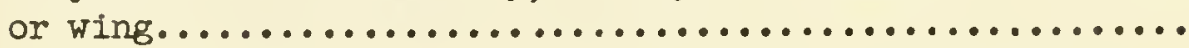

8b True raphe absent, pseudoraphe present on both valves......... 9

9a Frustules with thick longitudinal septae muning parallel to the valve face - TABELIARIA.

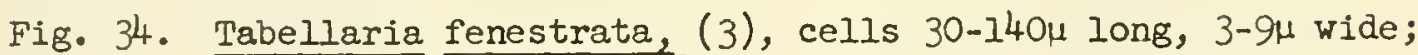
18-20 striae in 10 ; 4-8 intercalary bands per cell. In Great Lakes and Columbia River.

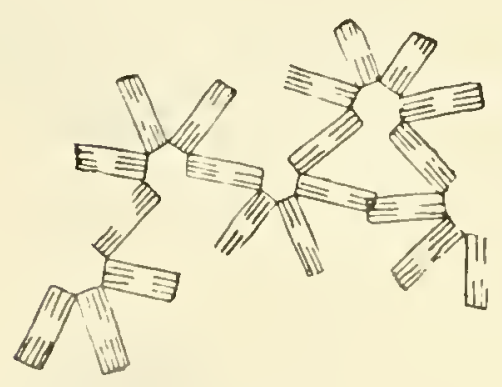

Colony

X 250 septum

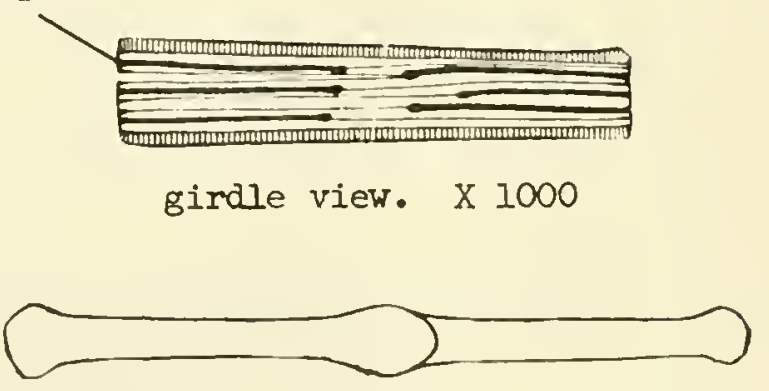

valve view. $\mathrm{X} 1000$

Notes: 
Fig. 35. Tabellaria flocculosa, (5), cells $12-50 \mu$ long, 5-16 wide; about 18 striae in 10 ; many intercalary bands. X 1000. In Great Lakes and Columbia River.

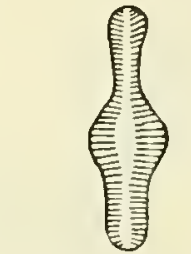

valve view

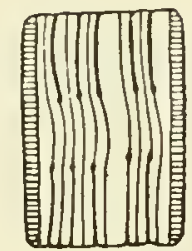

girale view

Notes :

$9 \mathrm{~b}$ Frustules without septre.......................... 10

10a Valves with thickened internal transverse ribs (costae), most of which extend completely across the valve face........... II

$10 \mathrm{~b}$ Valves without thickened internal transverse ribs........... 12

1la Valves symmetrical about the apical plane - DIATOMA

Fig. 36. Diatoma anceps, (5), cells $15-100 \mu$ long, 4-8 $\mu$ wide; internal costae narrow, $3-6$ in $10 \mu$; striae delicate, $18-20$ in $10 \mu$. $X$ 1000. In Colorado River.

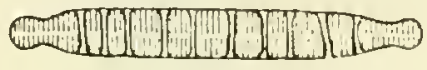

valve view

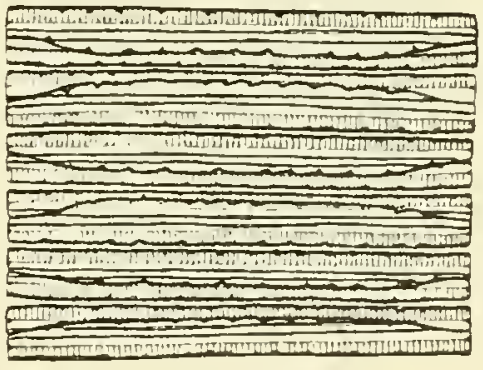

girdle view colony

Notes: 
Fig. 37. Diatoma elongatum, (5), cells 30-120 $\mu$ long, $2-4 \mu$ wide;

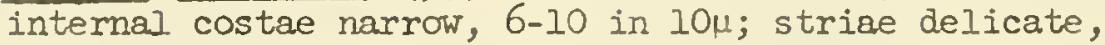
about 16 in $10 \mu . \times 1000$. In Great Lakes and Columbia. River.

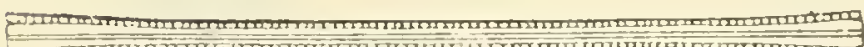

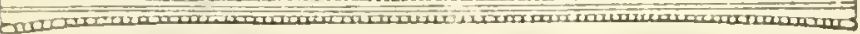

$$
\text { girdle view }
$$

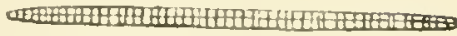
valve view of var. tenuis

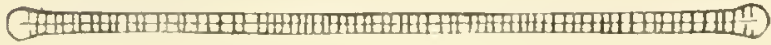

valve view

Notes:

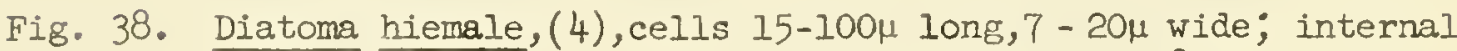

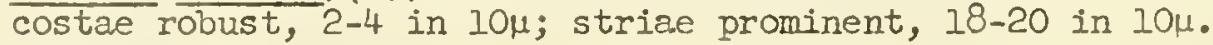
$\mathrm{X} 1000$.
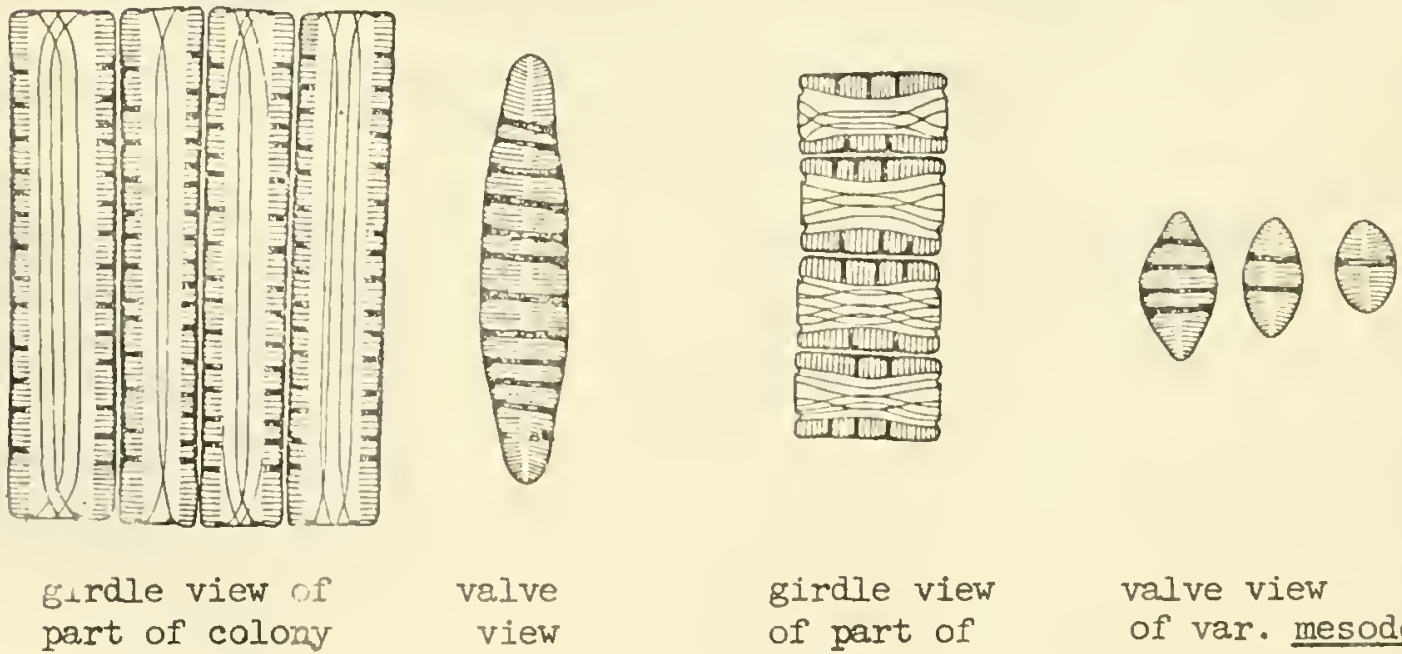
girdle view
of part of colony of var. mesodon

valve view of var. mesodon

Notes : 
Fig. 39. Diatoma vulgare, (5), cells 30-60 $\mu$ long, 10-13 $\mu$ wide; internal costae narrow, $6-8$ in $10 \mu$; striae very delicate, about 18 in $10 \mu$. Widely distributed.

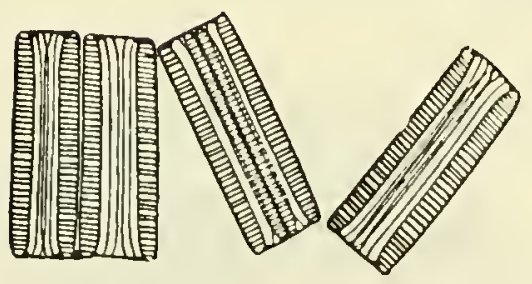

$$
\begin{gathered}
\text { Girdle view of } \\
\text { part of colony } \\
\text { X } 500
\end{gathered}
$$

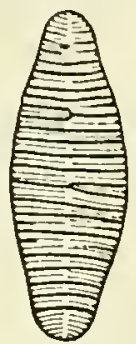

valve view

X 1000

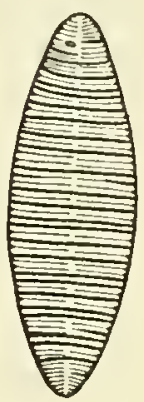

valve view, var. brevis. $\mathrm{X} 1000$

Notes:

Notes on other species of DIATOMA. 
ulb Valves asymetrical about the transapical plane - MERIDION

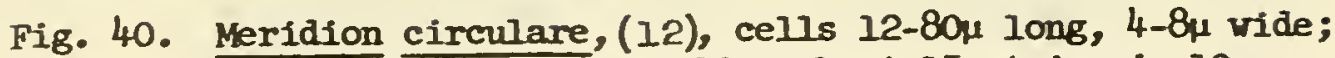
3-5 internal costae in 10\%; about 15 striae in $10 \mu$. $X$ 1000. Widely distributed.

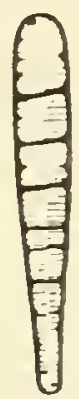

valve view

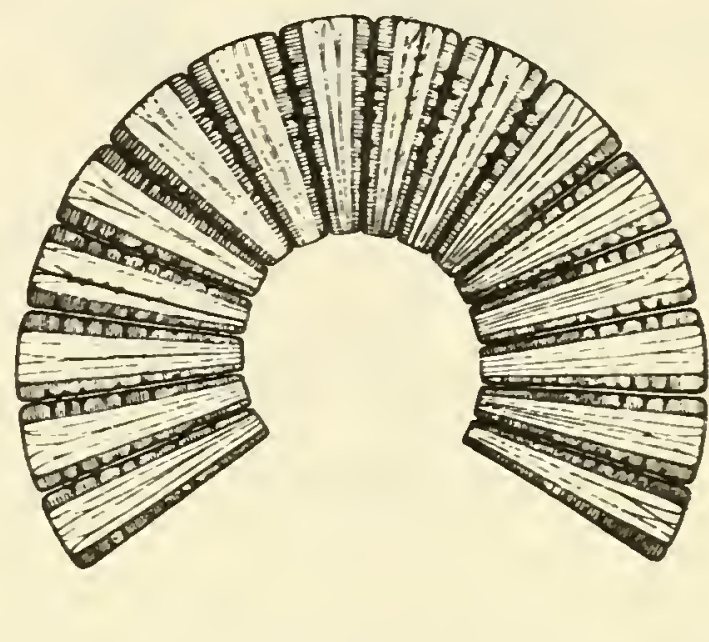

girdle view

Notes : 
12a Frustules with bulbous ends, slightly concave in girdle view, typically forming stellate colonies - ASTERIONELIA

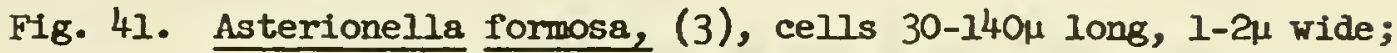
free ends inflated less than joined ends. Widely distributed.

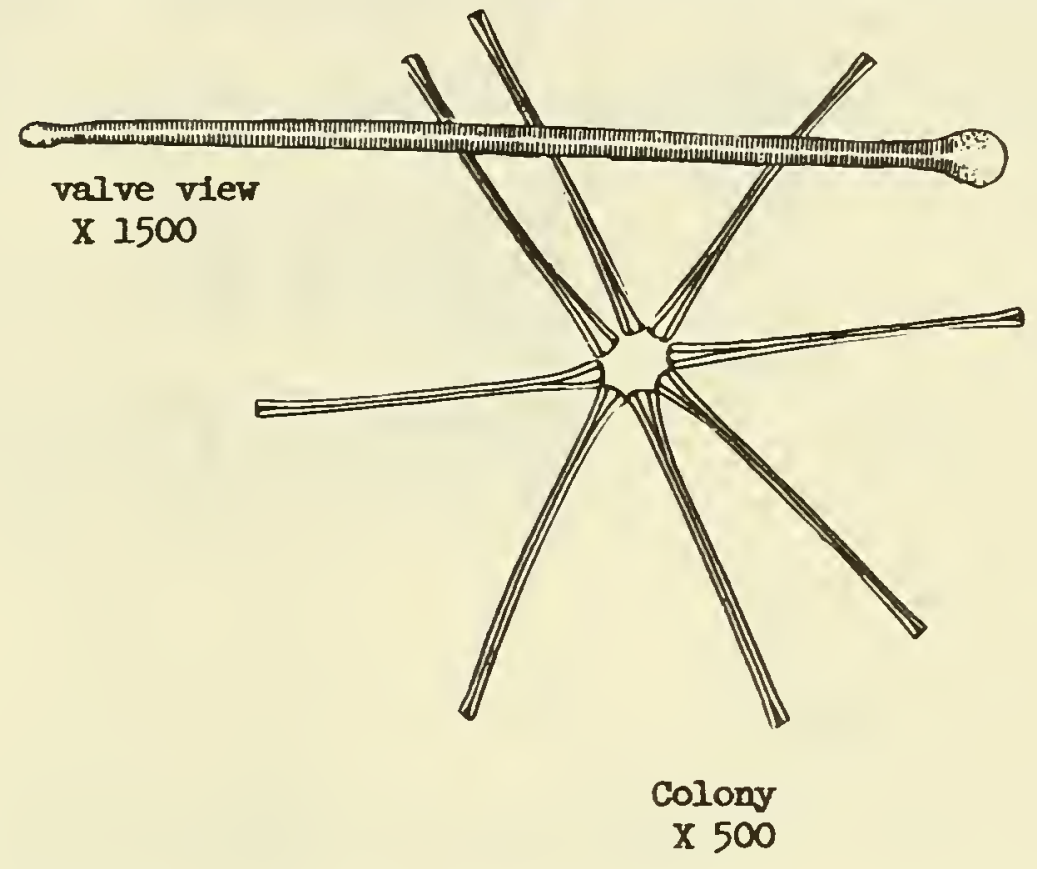

Notes:

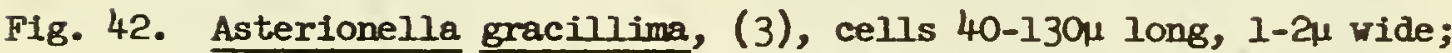
similar to $A$. formosa except that the two poles of the cell are of equal size in both valve and girdle view.

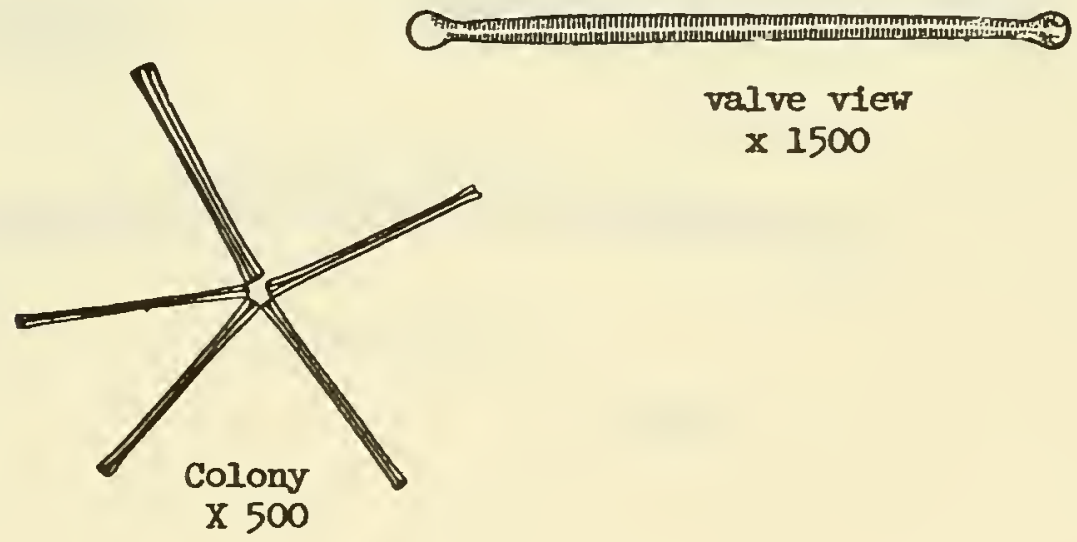

Notes : 
12b Frustules without bulbous ends, typically not forming

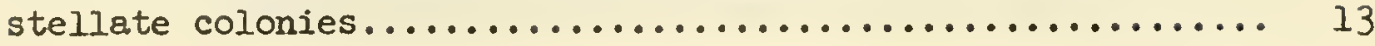

13a Valves symmetrical about the transapical plane............ 14

13b Valves asymetrical about the transapical plane - OPEPHORA

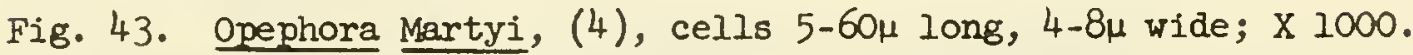

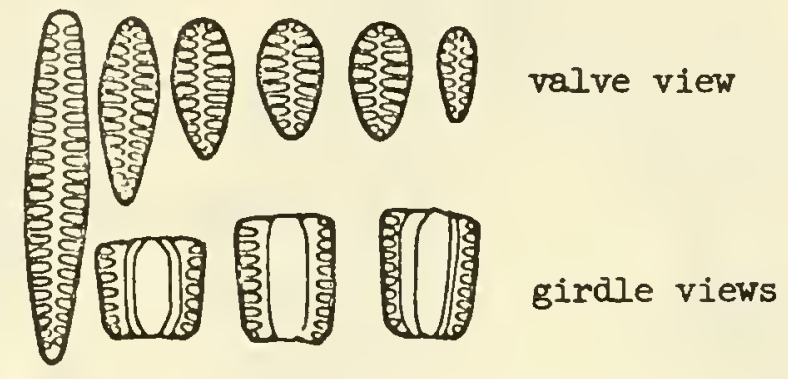

Notes :

14a Frustules typically forming ribbon-like chains, rarely solitary - FRAGTIARIA

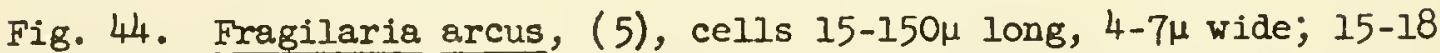
striae in lop; cells swollen on the concave side near the central area. X 1000 . Abundant in the Delaware and Columbia Rivers.

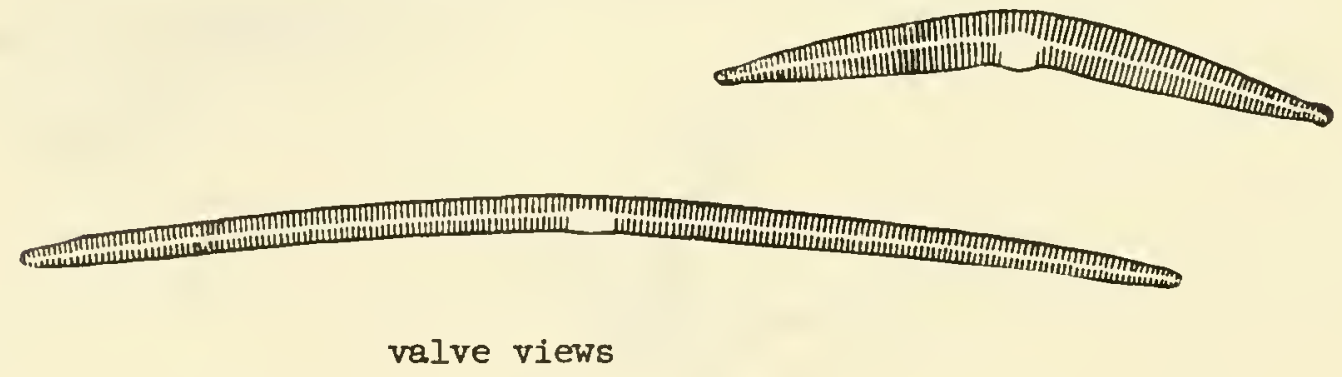

Notes: 
Fig. 45. Fragilaria brevistriata, ( 5 ), cells $12-28 \mu$ long, 3-5 $\mu$ wide;

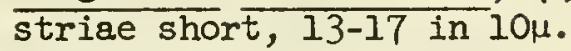

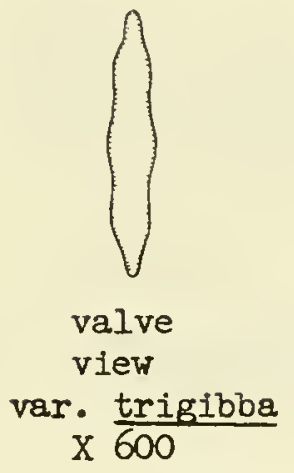

Notes:

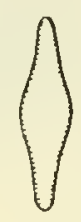

valve

view

var. inflata

$x 600$

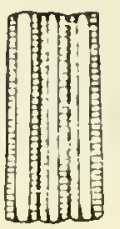

$$
\begin{aligned}
& \text { girdle } \\
& \text { view }
\end{aligned}
$$

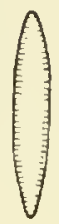

valve view

X 1000

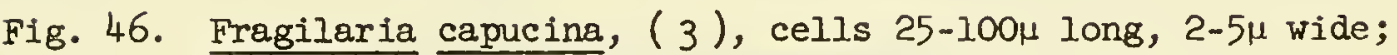
striae delicate, about 15 in $10 \mu$; clear central area.

$X 1000$. Abundant in northern waters.

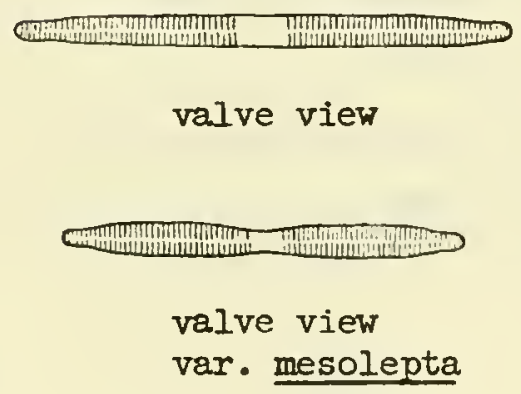

valve view

var. mesolepta

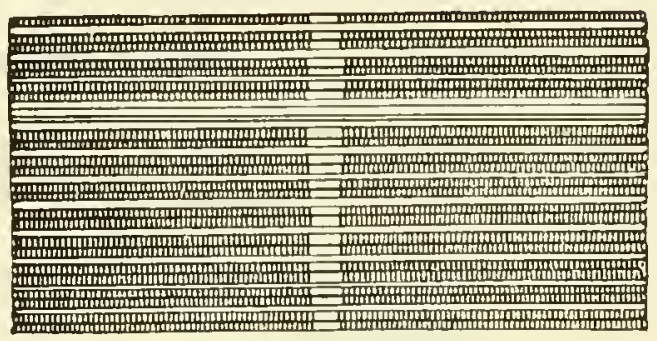

girdle view

Notes : 
Fig. 47. Fragilaria construens, ( 5 ), cells $7-25 \mu$ long, $5-12 \mu$ wide; striae delicate, 14-17 in 10 ; pseudoraphe broader in central region. X 1000 . Abundant in northerm waters.
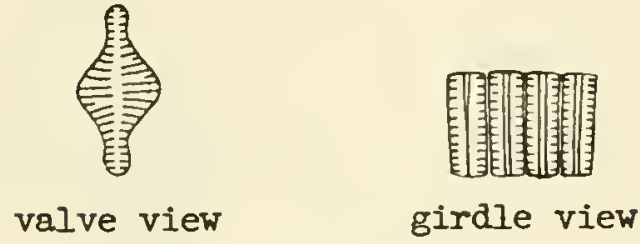

var. Subsalina

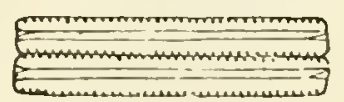

girdle view

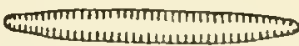

valve view

Notes :

Fig. 48. Fragilaria crotonensis, $(3,5)$, cells 40-150 $\mu$ long, $2-3 \mu$ wide; 15-18 striae in 104. X 1000. Widely distributed.
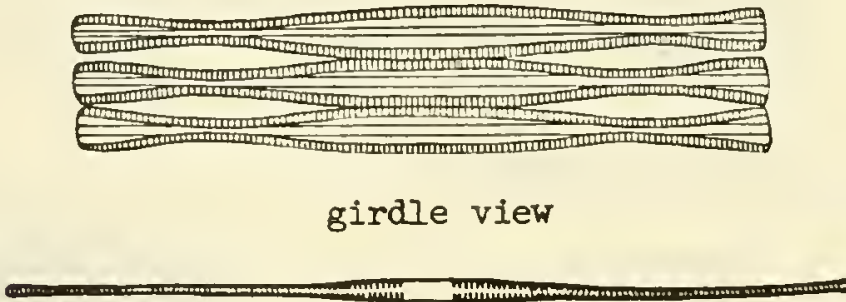

valve view

Notes :

Fig. 49. Fragilaria inflata, (12), cells $18-50 \mu$ long, 6-10 $\mu$ wide. $\mathrm{X} 1200$. In Great Lakes.

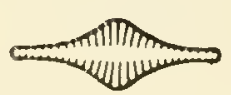

valve view

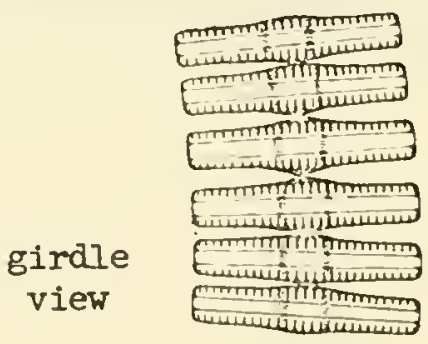

Notes : 
Fig. 50. Fragilaria intermedia, ( 5 ), cells $15-60 \mu$ long, $2-5 \mu$ wide;

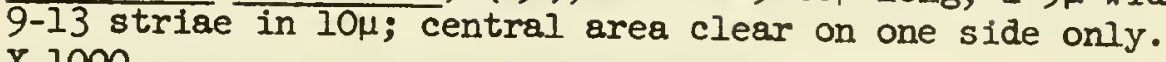
$\mathrm{X} 1000$.

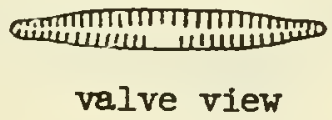

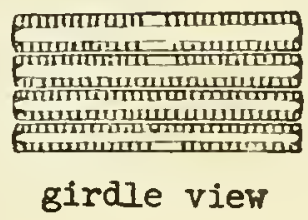

Notes:

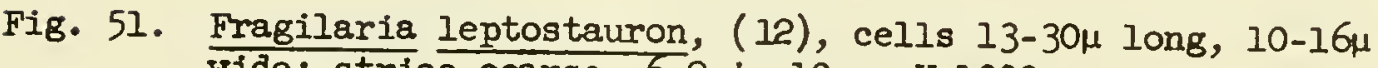
wide; striae coarse, 6-9 in $10 \mu$. X 1000 .
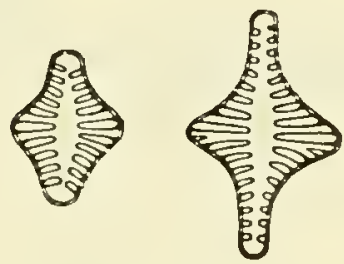

valve views

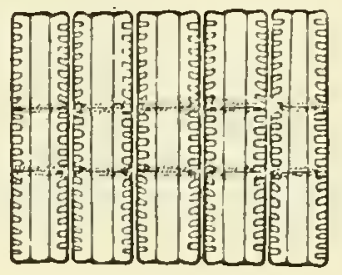

girdle view

Notes :

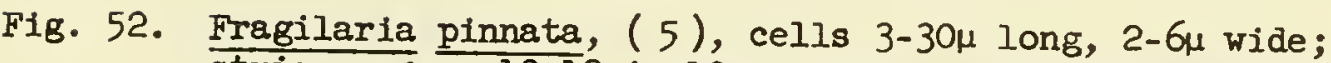
striae coarse 10-12 in $10 \mu . \times 1000$. Widely distributed.
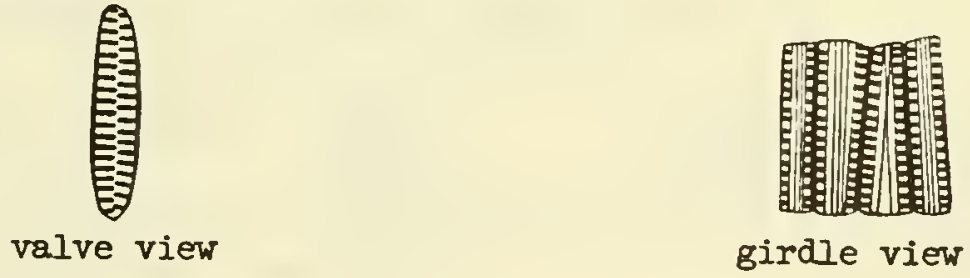

Notes : 
14b Frust:les typically solitary, sometimes forming stellate colonies; striae often appearing as costae - SYNEDRA

Fig. 53. Synedra actinastroides, ( 5 ), cells $35-64 \mu$ long, $2-4 \mu$ wide; striae snort, marginal, 14 in $10 \mu$. X 580 .

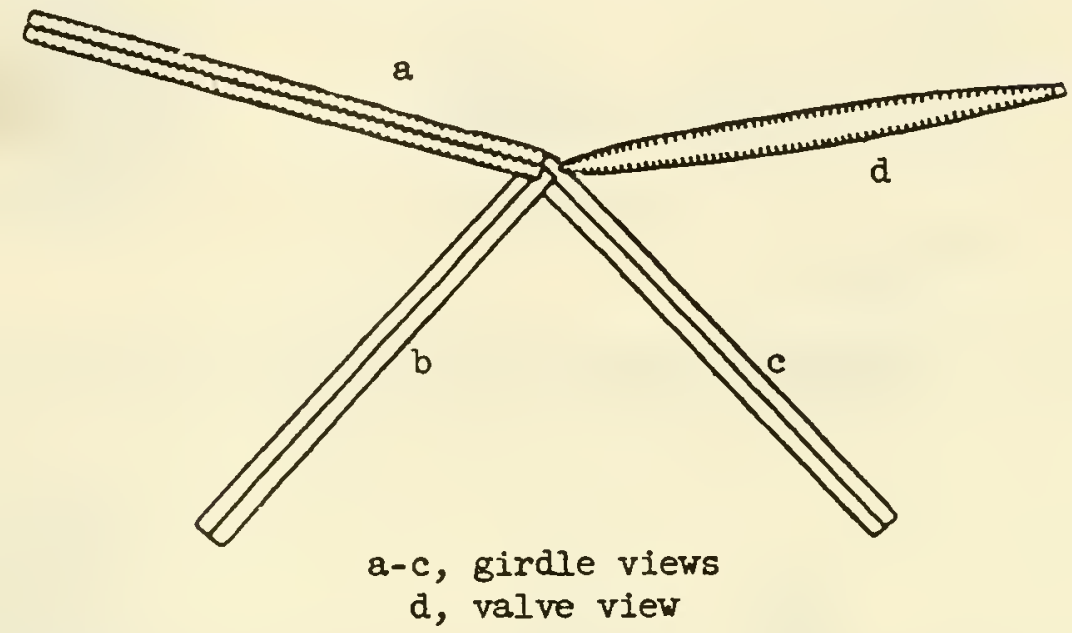

Notes :

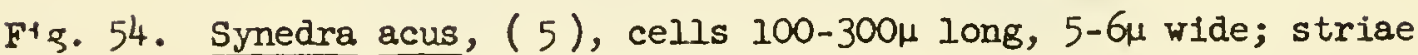

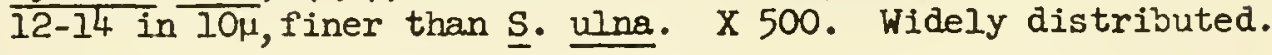

valve view, var. angustissima

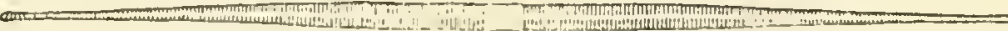

valve view

valve view, var. radians

Notes: 
Fig. 55. Synedra nana, ( 5 ), cells $50-90 \mu$ long, 1-2 $\mu$ wide; striae very light, $25-30$ in $10 \mu . x 1000$. Widely distributed.

\section{valve view}

Notes :

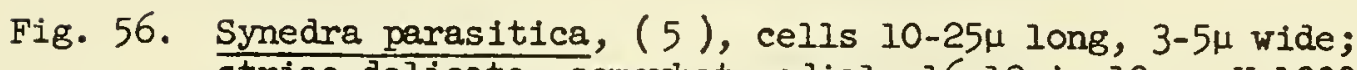
striae delicate, somewhat radial, $16-19$ in $10 \mu . x 1000$. Sometimes parasitic on Nitzschia sigmoides.

Notes :

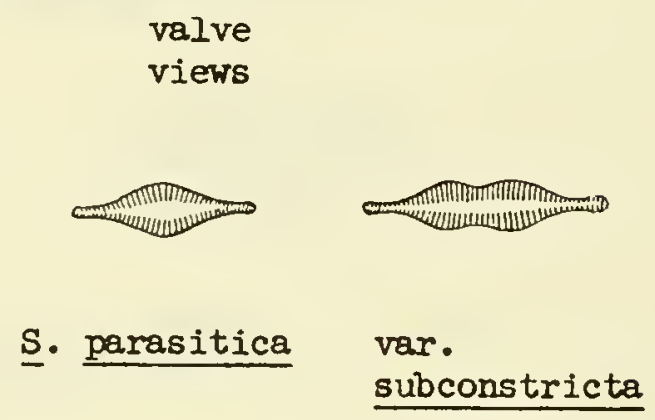

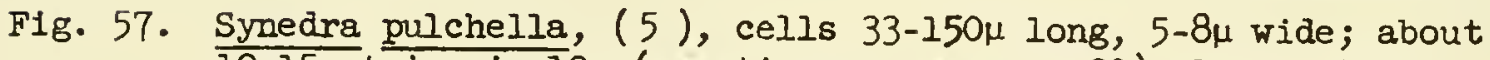
12-15 striae in $10 \mu$ (sometimes as many as 20); large clear refractive central area. X 1000.

valve views

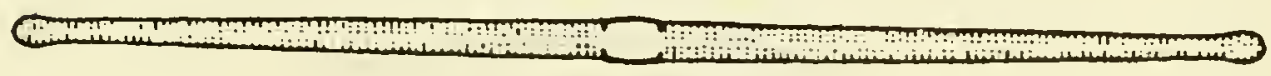

S. putchella

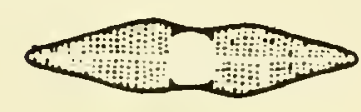

var. lanceolata

form constricts

Notes :

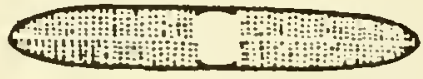

var. naviculacea 
Fig. 58. Synedra rumpens, ( 5 ), cells $15-70 \mu$ long, $2-3 \mu$ wide; $19-20$ striae in 101; central area variable or completely absent. X 1000 .

$$
\text { valve views }
$$

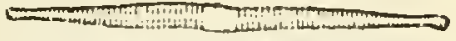

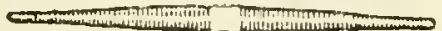

S. rumpens

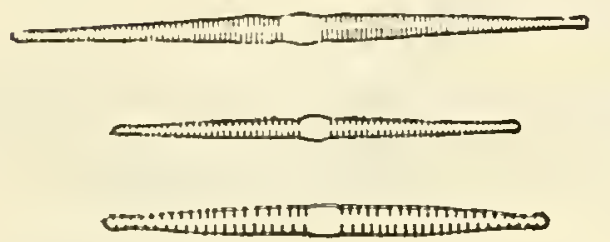

var. famillaris

var. scotica

var. fragilarioides

Notes :

Fig. 59. Synedra tabulata, ( 5 ), cells $60-150 \mu$ long, $2-5 \mu$ wide;

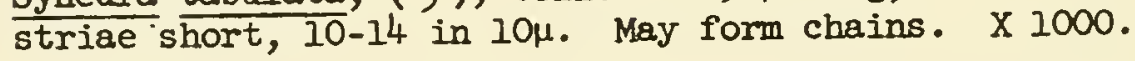
valve views

Notes : 


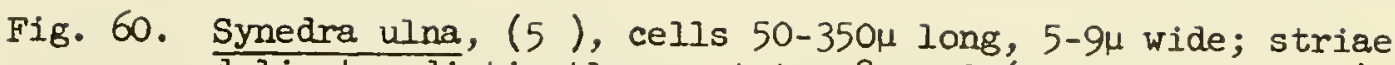
delicate, distinctly punctate, 8 - 12 (usually about 10)

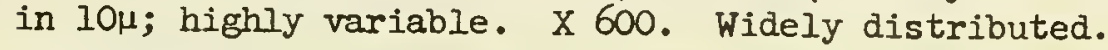

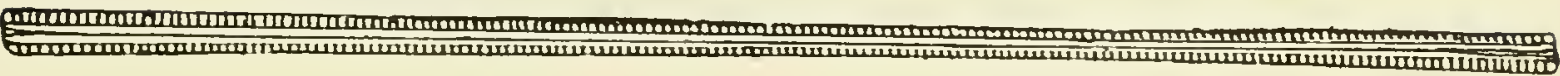

\section{girdle view, s. ulna}

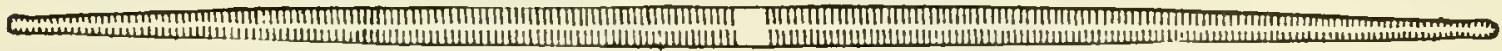

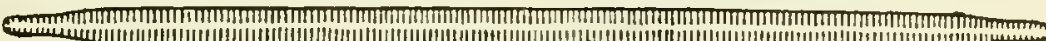

valve views, S. $\underline{\underline{u} \text { na }}$

\section{valve views}

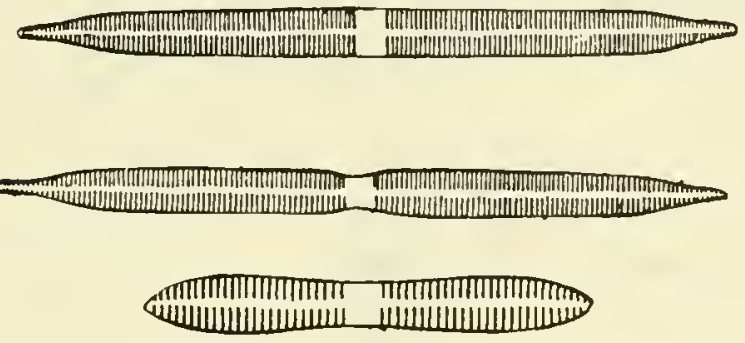

var. oxyrhynchus

var. oxyrhynchus, form contracta

var. Impressa

Notes: 
Fig. 61. Synedra Vaucheriae, ( 5 ), cells 10-40 1 long, $2-4 \mu$ wide; 12-16 striae in 10 $\mu$; central area clear and thickened only on one side. X 1000. Widely distributed.

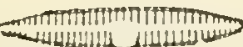

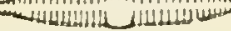

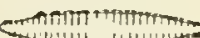

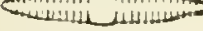

r.

valve views,

S. Vaucheriae var. capitellata

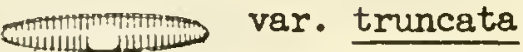

Notes:

Notes on other species of SYNEDRA. 
15a Raphe evident on at least one valve................... 16

15b Raphe not evident, concealed in a keel or wing............ 35

16a Valves similarly ornamented, raphe on both valves.......... 19

$16 \mathrm{~b}$ Valves not similarly ornamented, raphe on one valve, opposing valve with pseudoraphe, or with rudimentary

raphe near valve poles................................ 17

17a Valves elliptical, never linear, sometimes bent along the apical axis - COCCONEIS

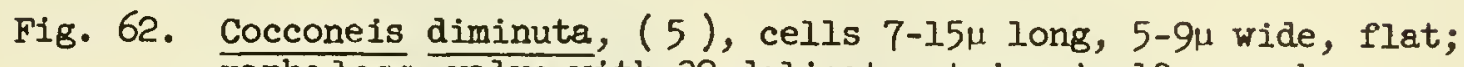
rapheless valve with 32 delicate striae in $10 \mu$; raphebearing valve with 13 coarsely punctate striae in $10 \mu$. $\mathrm{X} 1000$.

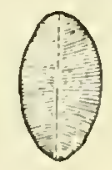

valve with raphe

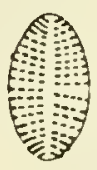

valve

without raphe

Notes : 


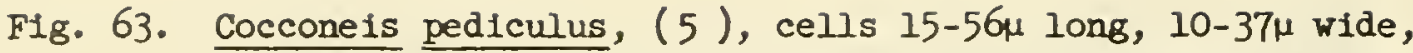
strongly bent along the apical axis; valve with raphe has

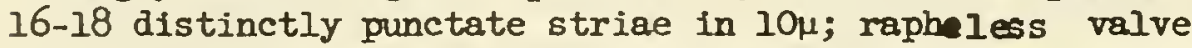
with 15-17 striae in 10 , which are crossed by several widelyspaced, undulating, longitudinal rows of coarse punctae. $X 1000$. Widely distributed.
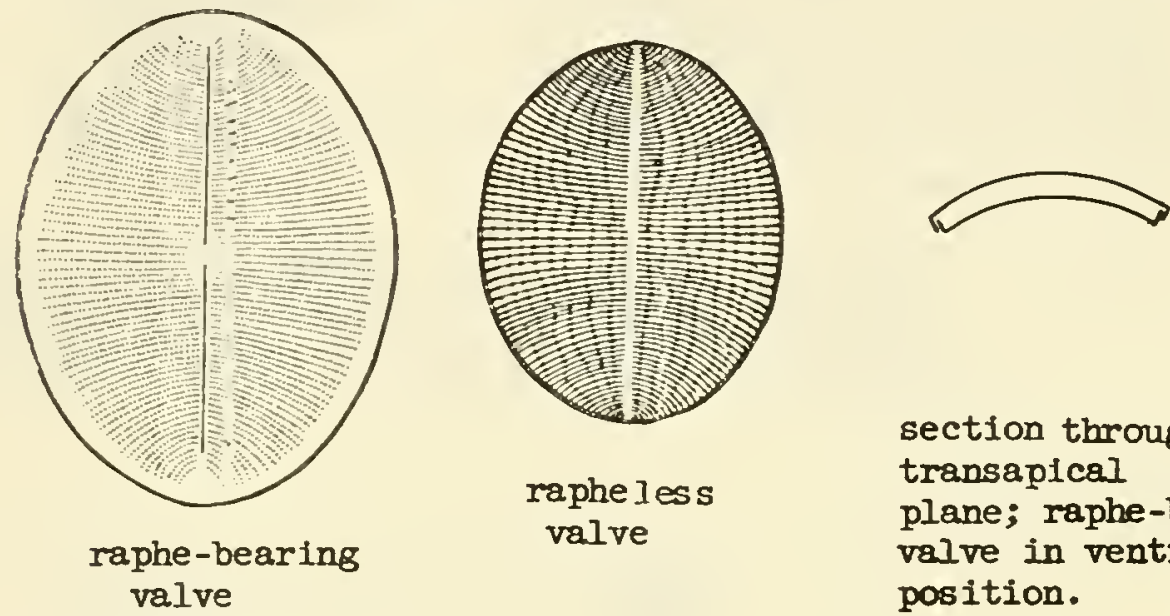

Notes:

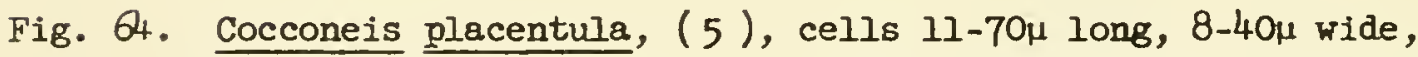
flat or only slightly curved; raphe-bearing valve with about 23 striae in $10 \mu$, rapheless valve with about 25 striae in

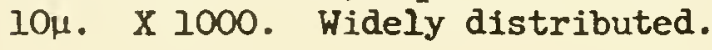

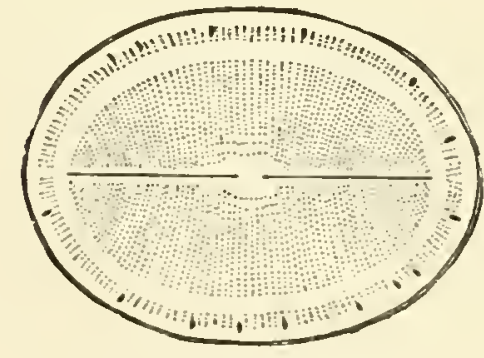

raphe-bearing valve

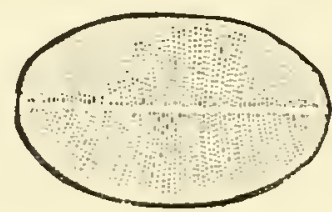

rapheless valve

Notes: 


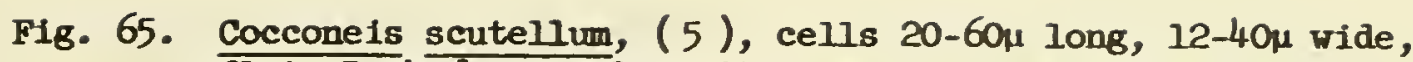
flat. Raphe less valve with coarsely punctate striae. X 1000 .

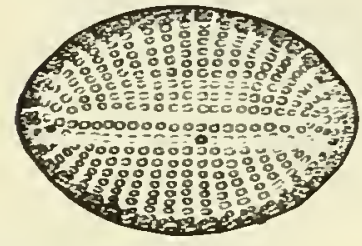

Rapheless valve

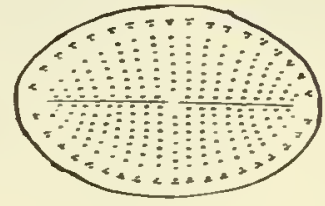

raphe-bearing valve

Notes :

Notes of other species of COCCONEIS. 
17b Valves not elliptical, usually linear, and usually bent along the transapical axis............................ 18

18a Valves symmetrical about the transapical plane, one valve with completely developed raphe, opposing valve with pseudoraphe - ACENANTHES

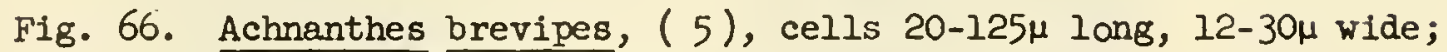
coersely punctate. X 1000.

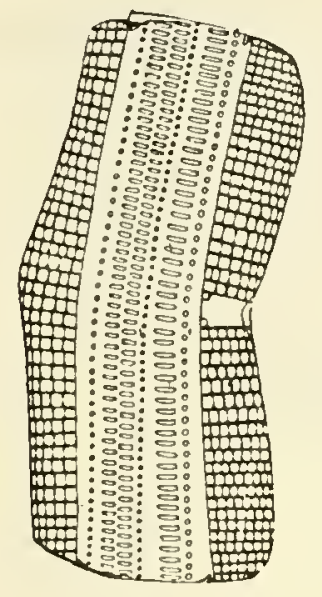

girdle view

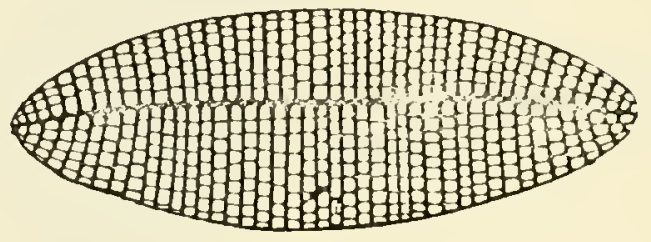

rapheless valve

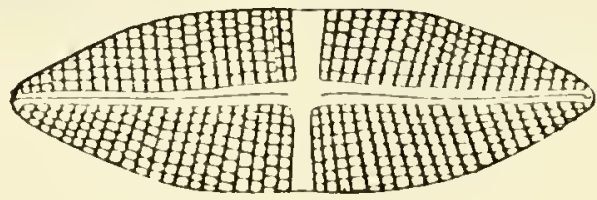

raphe-bearing valve

Notes :

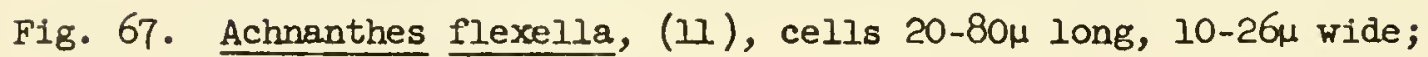
sigmoid raphe. X 1500.

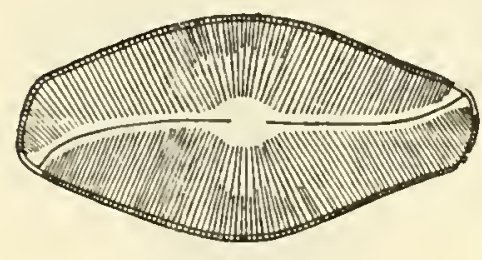

raphe-bearing valve

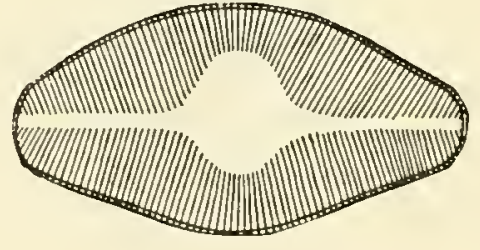

rapheless valve

Notes : 


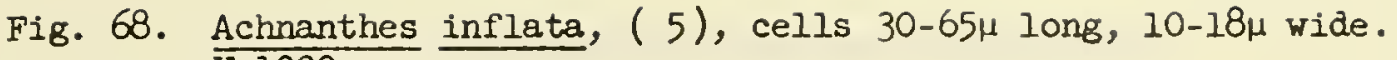
$\mathrm{X} 1000$.

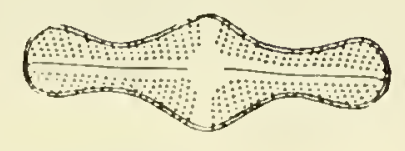

raphe-bearing valve

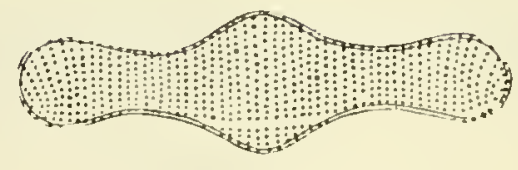

rapheless valve

Notes :

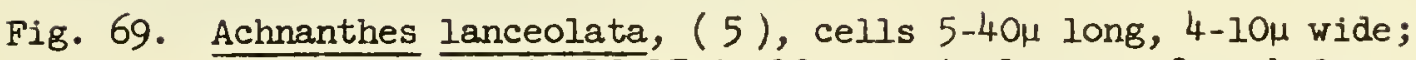
striae prominent, 13-17 in 10 ; central area of rapheless valve with horseshoe-shaped spot. X 1500. Common in Great Lakes.

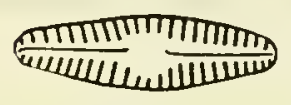

raphe-bearing valve

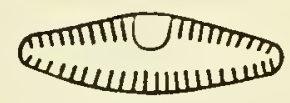

rapheless valve

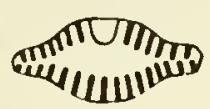

rapheless valve of var. rostrata

Notes:

Fig. 70. Achnanthes minutissima, ( 5 ), cells $5-40 \mu$ long, $2-4 \mu$ wide; striae delicate, about 35 in $10 \mu$. Curved girdle view very common. X 1500. Widely distributed.

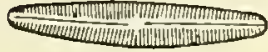

raphe-bearing valve

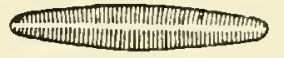

rapheless

valve

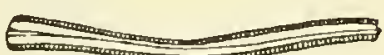

girdle view

Notes: 
Fotes on other species of ACENANTHES.

$18 \mathrm{~b}$ Valves asymmetrical about the transapical plane, one valve with completely developed raphe, opposing valve with rudimentary raphe near valve poles - RHOICOSPHENIA

Fig. 71. Rhoicosphenia curvata, ( 5 ), cells $12-75 \mu$ long, $4-8 \mu$ wide; curved and wedge-shaped in girdle view; $12-15$ striae in 10\%. X 1000. Widely distributed.

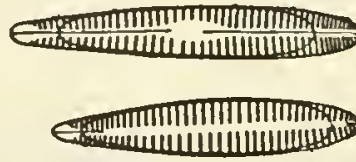

valve views

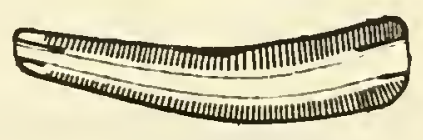

girdle view

Notes : 
190 Raphe rudimentary, short, near poles only - EUNOTIA.

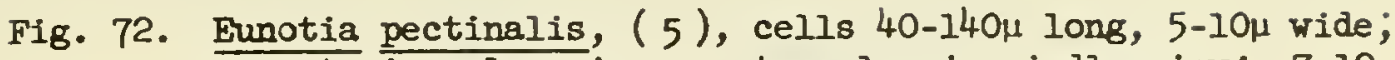
arcuate in valve view, rectangular in girdle view; 7-12 striae in $10 \mu . \quad X 1000$. Common in soft waters.

valve views

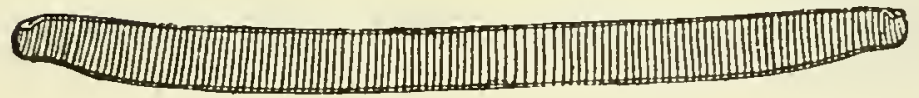

E. pectinalis

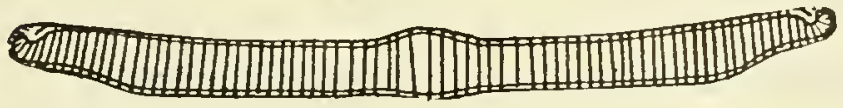

var. ventralis

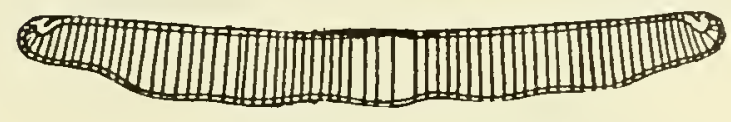

var. undulata

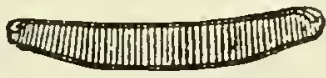

girdle view

var. minor

E. pectinalis

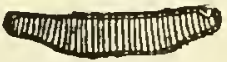

var. minor

form $\underline{\text { impressa }}$

Notes :

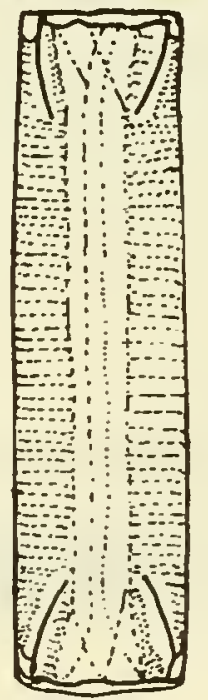


19b Raphe fully developed, extending the length of the valves..... 20

20a Valves symmetrical about both the transapical and apical plane....................................... 24

$20 \mathrm{~b}$ Valves asymetrical about either the apical or transapical plane......................................... 21

2la Valves symetrical about the transapical plane, asymetrical about the apical plane............................ 23

2lb Valves asymmetrical about the transapical plane, symetrical about the apical plane............................ 22

22a. Valve margins with longitudinal "shadow"-lines - GOMPHONEIS

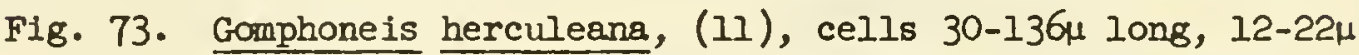
wide; 9-12 striae in $10 \mu$; central area rounded with an isolated puncta. X 1000 .

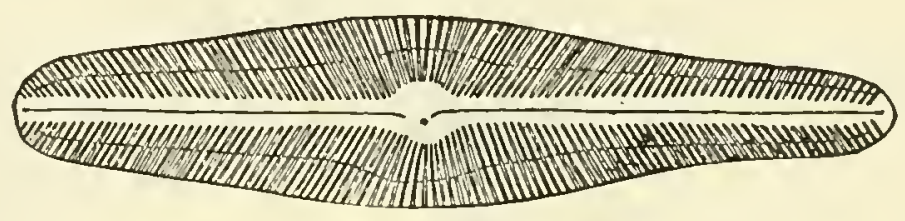

valve view

Notes :

22b Valve margins lacking longitudinal "shadow"-lines - GOMPHONEMA

Fig. 74. Gomphonema abbreviatum, (5), cells $7-34 \mu$ long, $2-6 \mu$ wide;

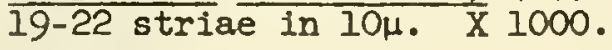

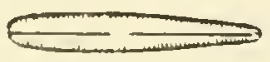

valve view

Notes : 


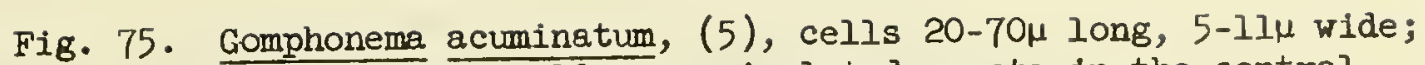

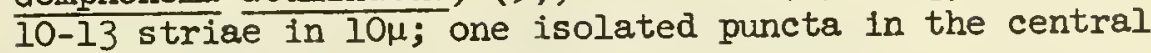
area. X 1000 .

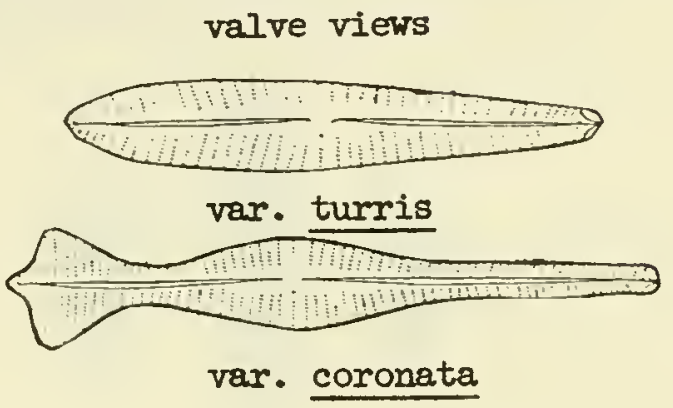

Notes:

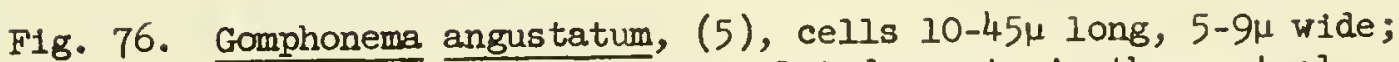

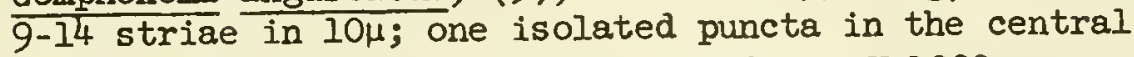
area; easy to confuse with G. parvulum. X 1000.

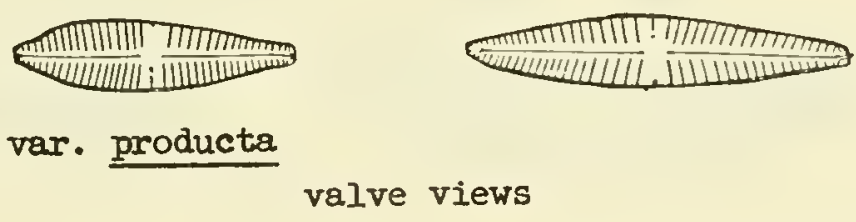

Notes :

Fig. 77. Gomphonema constrictum, (5), cells $25-65 \mu$ long, $8-14 \mu$ wide;

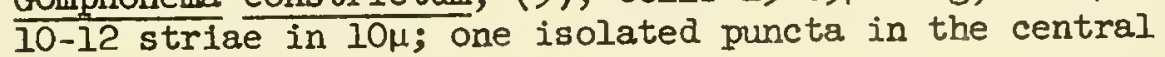
area. $\mathrm{X} 1000$.

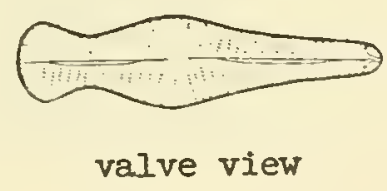

Notes: 


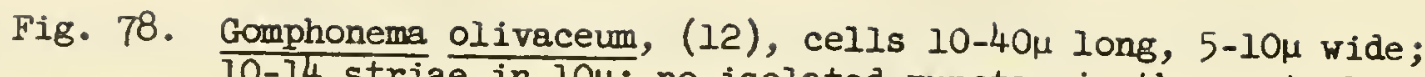
10-14 striae in $10 \mu$; no isolated punctae in the central area. X 1000. Widely distributed.

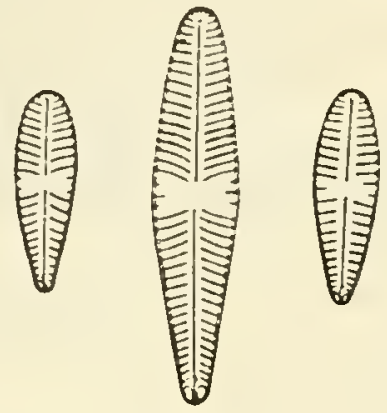

valve views

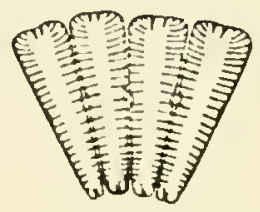

girdle view

Notes :

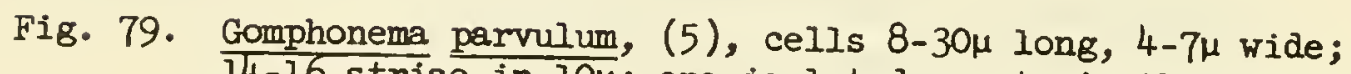
14-16 striae in 10\%; one isolated puncta in the central area. X 1000 .

valve views

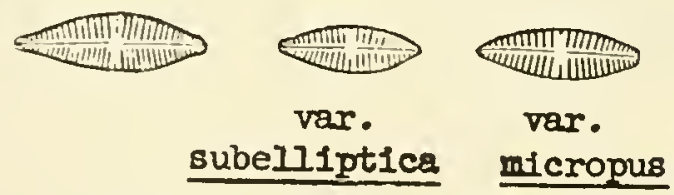

Notes : 
Notes on other species of GOMPHONEMA.

23a Valve faces parallel - CMMBELIA

Fig. 80. Cymbella affinis, (5), cells 20-70 1 long, 7-16 wide; 9-12 striae in 10\%; ventral median striae ending in an isolated prominent puncta. X 1000.
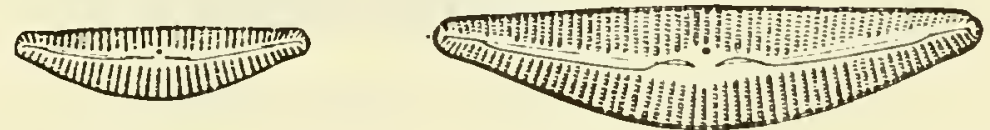

valve views

Notes: 
Fig. 81. Cymbella cistula, (5), cells 35-180 $\mu$ long, $15-36 \mu$ wide; $6-9$ striae in $10 \mu$; two or more prominant punctae in the central area. $\mathrm{X} 1000$.

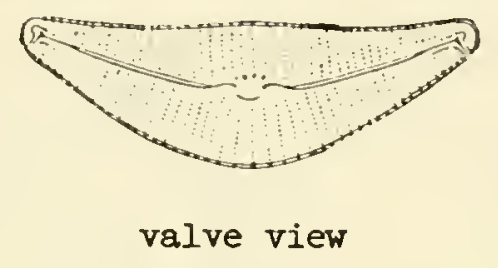

Notes :

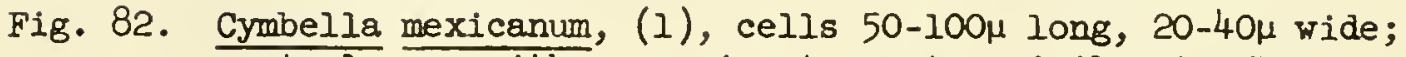
central area with a prominant puncta; similar to $\mathrm{C}$. tumida, but striae have coarser punctae. X 800 .

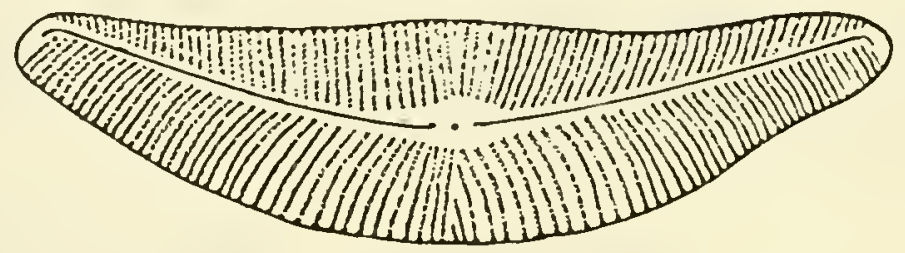

valve view

Notes:

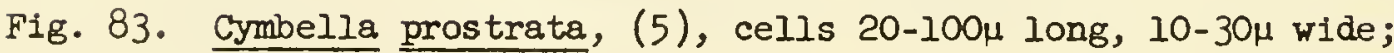
$7-10$ striae in $10 \mu . \times 1000$.

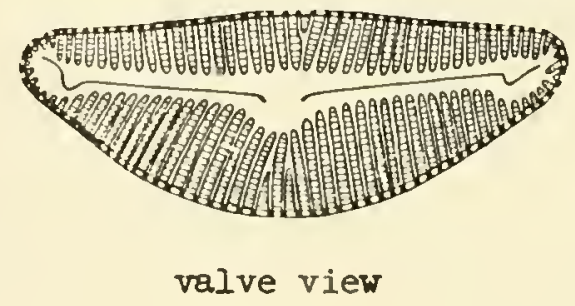

Notes : 
Fig. 84. Cymbella sinuata, (5), cells $10-40 \mu$ long, 4-9 $\mu$ wide; 9-1I striee in $10 \mu$; do not confuse with Achnanthes sp. $\mathrm{X} 1000$.

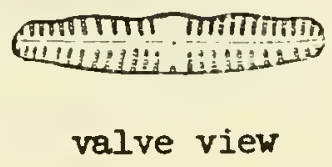

Notes :

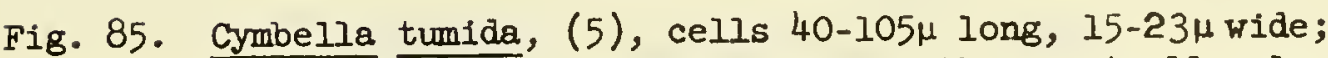

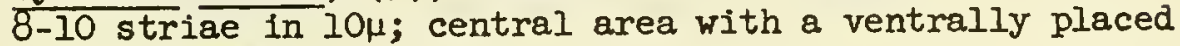
isolated puncta. X 1000 .

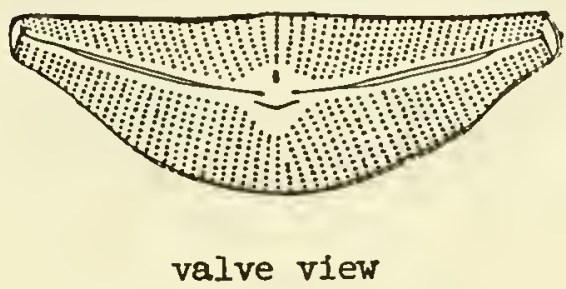

Notes :

Fig. 86. Cymbella turgida, (5), cells 30-100 $\mu$ long, 9-25 $\mu$ wide; 7-9

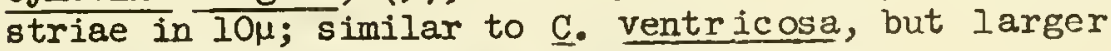
and with more conspicuous punctae. X 1000.

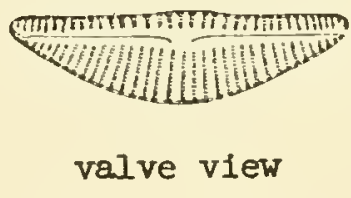

Notes: 


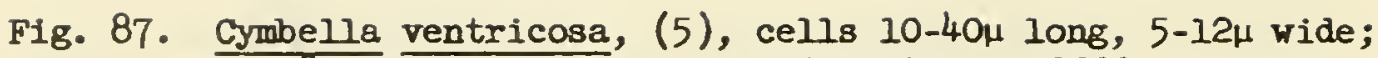

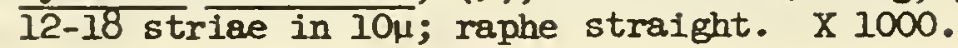
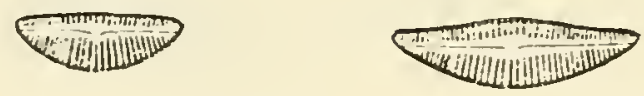

valve views

Notes :

Notes on other species of CMMBEIIA.

23b Valve faces not parallel, both valve faces can be seen in girdle view - AMPHORA

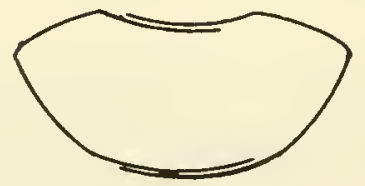

A diagrammatic polar view of Amphora, (7). 
Fig. 88. Amphora coffeaeformis, (5), cells $20-50 \mu$ long, 10-18 $\mu$ wide; 16-25 striae in $10 \mu$; intercalary bands fine, about 21 in

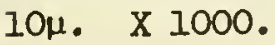

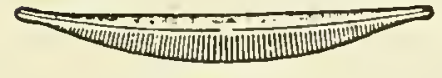

valve view

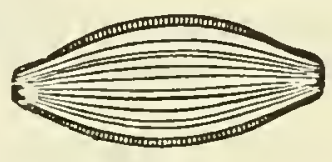

girdle view

Notes:

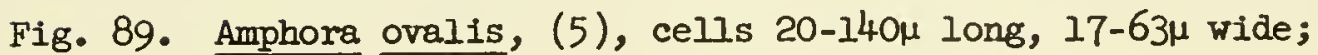
10-13 striae in 10\%. X 1000.

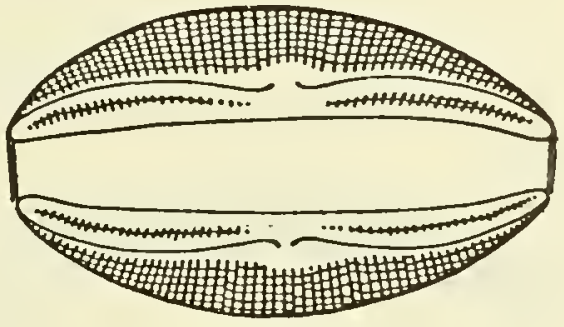

girdle view

Notes :

Notes on other species of AMPHORA. 
24a Valves with elongate central or terminal nodules.......... 25

$24 \mathrm{~b}$ Valves without elongate central or terminal nodules........ 26

25a Central nodule drawn out to at least half the length of the valve - AMPHIPLEURA

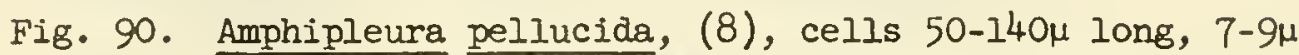
wide; punctae delicate and difficult to see. $\mathrm{X} 1000$.

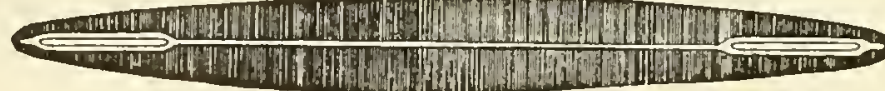

valve view

Notes :

25b Central nodule drawn out less than half the length of the valve - FRUSTULIA

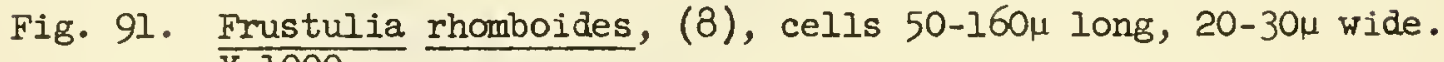
$\mathrm{X} 1000$.

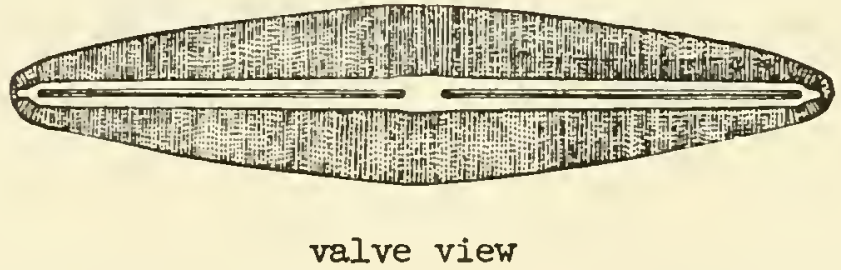

Notes : 


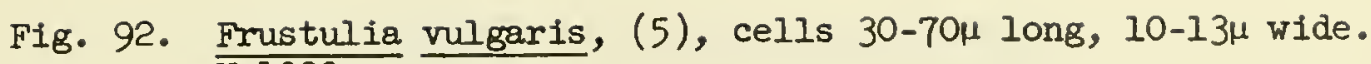
$\mathrm{X} 1000$.

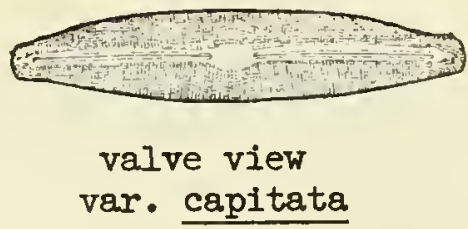

Notes:

26a Valves with longitudinal "shadow"-lines or blank speces...... 27

26b Valves without longitudinal lines or blank spaces........... 29

27a Transverse striae continuous, crossed by one or two longitudinal "shadow"-lines paralleling valve margin - CALONEIS

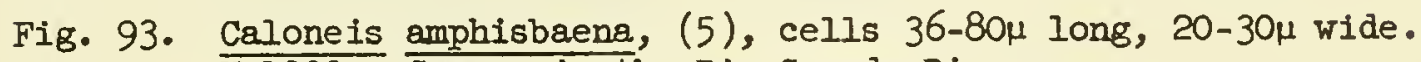
$\mathrm{X} 1000$. Common in the Rio Grande River.

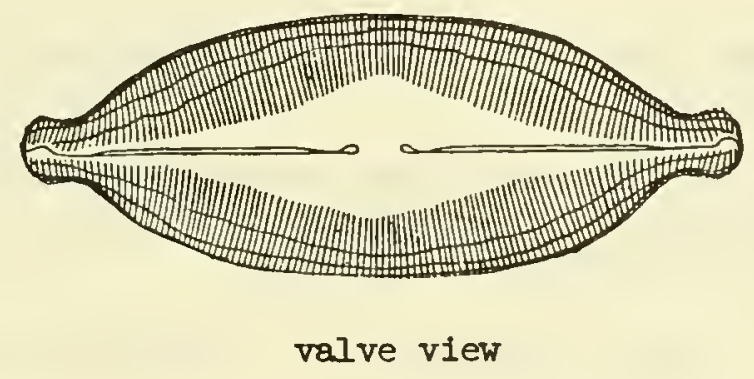

Notes :

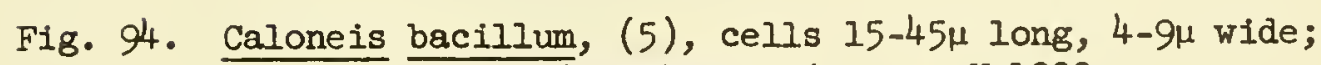
can be mistaken for Stauroneis sp. X 1000 .

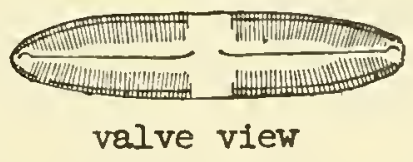

Notes : 
Notes on other species of CALONEIS.

27b Transverse striae discontinuous, interrupted by blank spaces

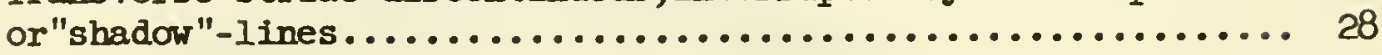

28a Longitudinal "shadow"-lines or blank spaces near valve margins; ends of raphe near central nodule usually turned in opposite directions - NEIDIUM

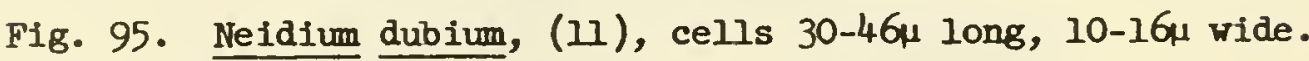
$\mathrm{X} 1000$.

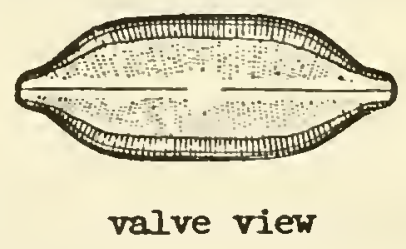

Notes : 


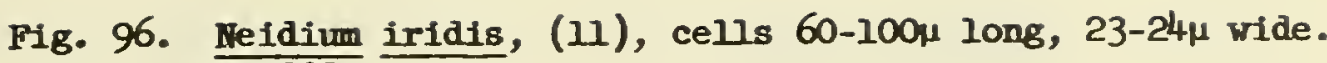
X 1000 .

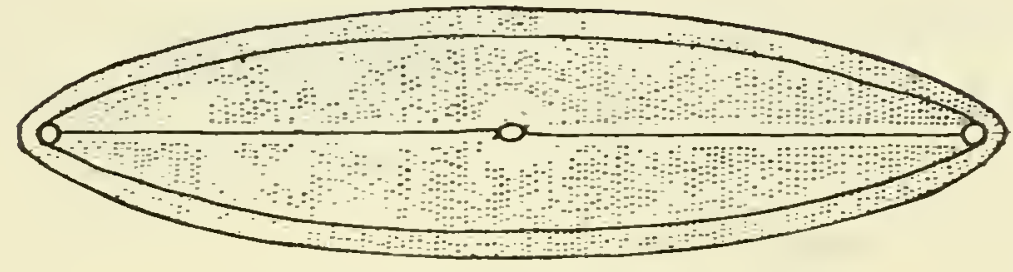

valve view

var. firma

Notes:

Notes on other species of NEIDIUM.

$28 \mathrm{~b}$ Longltudinal "s'iadow"-lines or blank speces scattered, central pores of raphe near central nodule turned if at all in the same direction - ANOMOEONEIS 
Fig. 97. Anomoeoneis exilis, (11), cells $10-35 \mu$ long, 4-6 $\mu$ wide. $\mathrm{X}$ 1000. Abundant in the southern Colorado River.

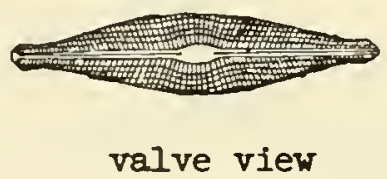

Notes:

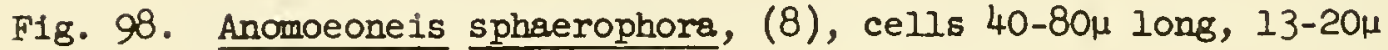
wide. X 1000 .

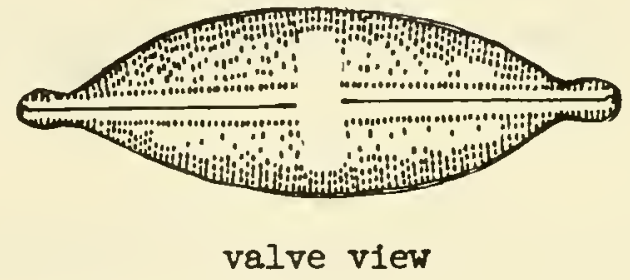

Notes:

Notes on other species of ANOMOEONEIS 


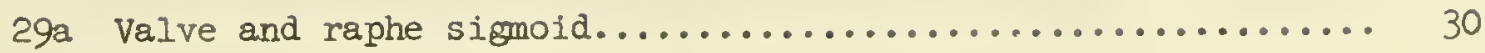

$29 \mathrm{~b}$ Valves and raphe not sigmoid............................ 31

30a Valves with transverse and longitudinal striae - GYROSIGMA

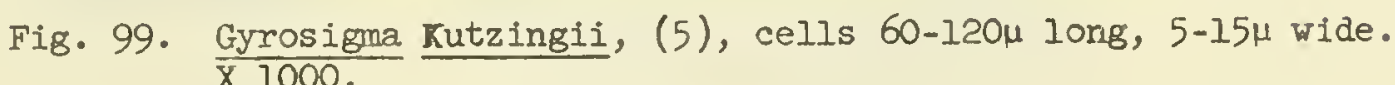

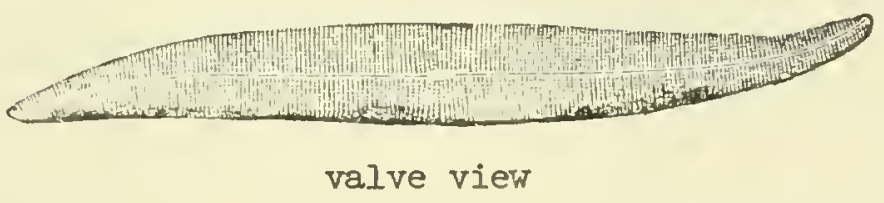

Notes:

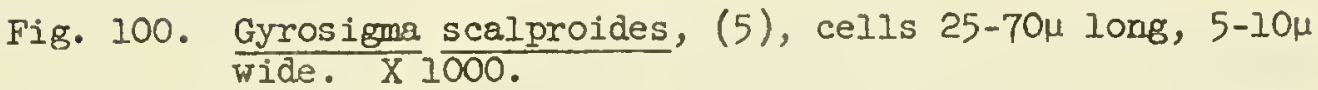

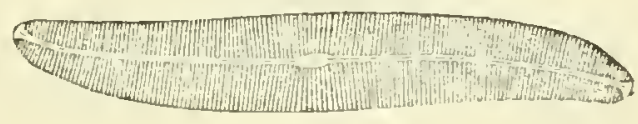

valve view

Notes:

30b Valves with transverse and oblique striae - PLEUROSIGMA 


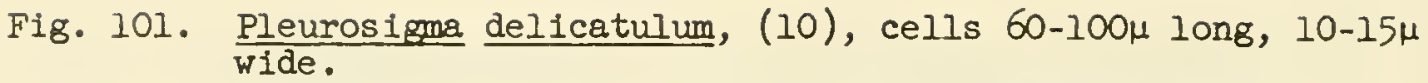

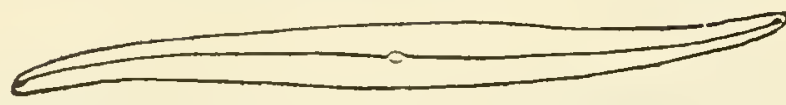

valve view

$\mathrm{X} 495$

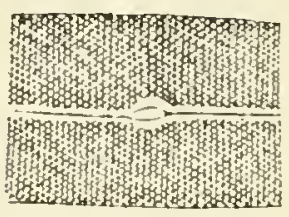

valve view

$\mathrm{X} 1300$

Notes:

31a Frustules with septae - MASTOGLOIA

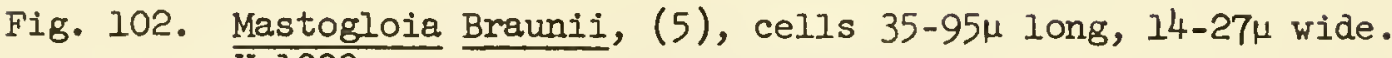
$\mathrm{X} 1000$.
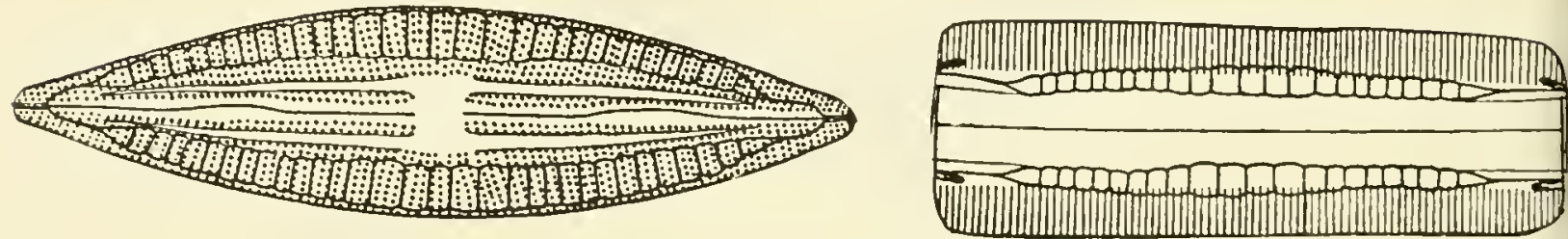

valve view

girdle view

Notes :

31b Frustules without septae....................... 32

32a Raphe enclosed in a siliceous rib - DIPLONEIS 
Fig. 103. Diploneis interrupta, (5), cells $30-80 \mu$ long, $7-15 \mu$ wide.

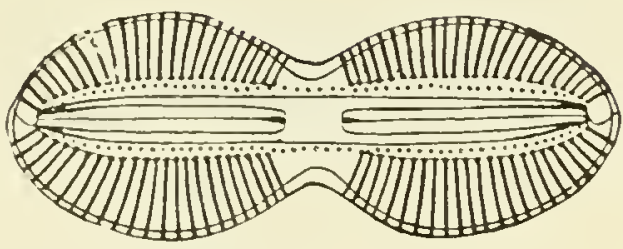

valve view

Notes :

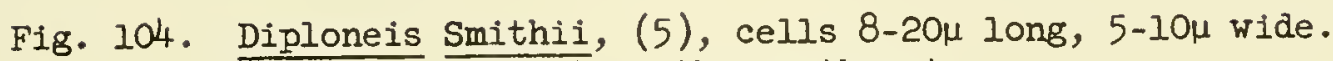
$\mathrm{X} 1000$. Abundant in the southwest.

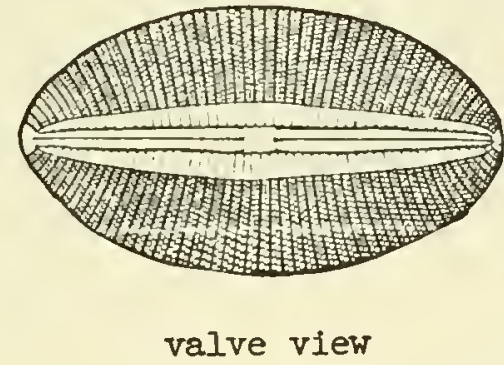

Notes:

Notes on other species of DIPLONEIS. 
$32 \mathrm{~b}$ Raphe not enclosed in a siliceous rib................. 33

33a Valves with chambered striae appearing as heavy costae; valves usually with parallel sides and broadly rounded poles - PINNULARIA

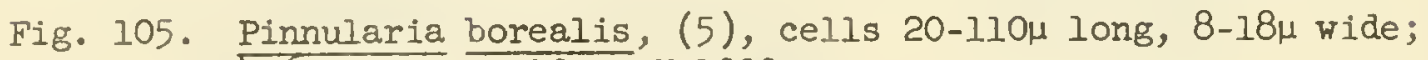
$4-6$ striae in $10 \mu . \times 1000$.

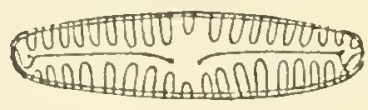

$$
\begin{aligned}
& \text { valve view }
\end{aligned}
$$

Notes :

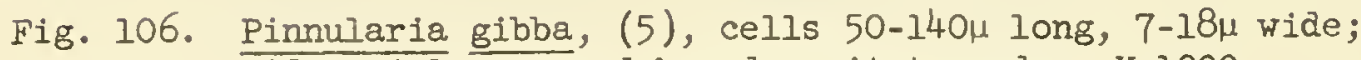
wide axial area and broad capitate ends. X 1000.

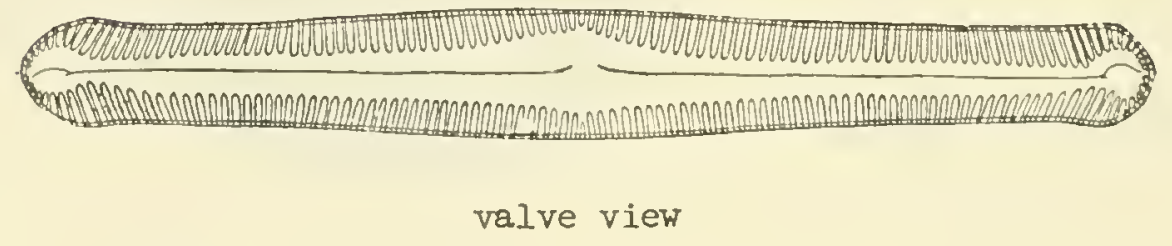

Notes:

$33 \mathrm{~b}$ Valves with striae appearing otherwise.............. 34

34 Central area extending laterally to the margins of the valve, striae absent along lateral margins of the central area - STAURONEIS 


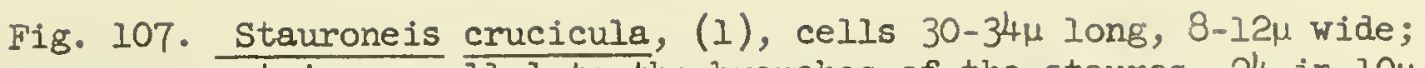
striae parallel to the branches of the stauros, 24 in $10 \mu$. $\mathrm{X} 800$.

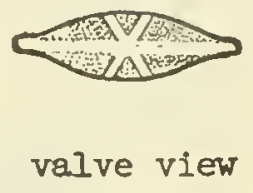

Notes :

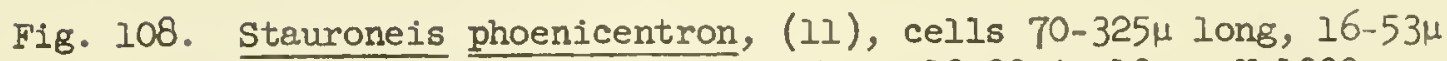
wide; striae distinctly punctae, $12-20$ in $10 \mu . X 1000$.

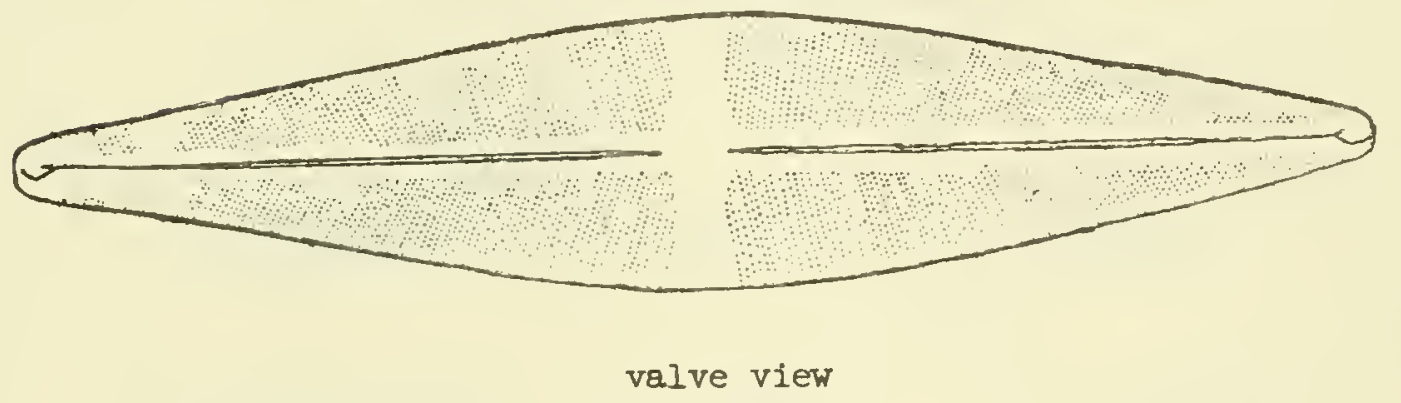

Notes :

34b Central area not extending to the mains of the valve, striae present along lateral margins of the central area - NAVICULA 


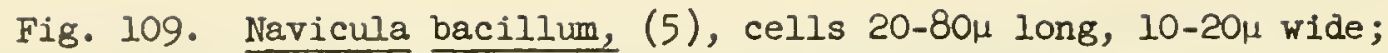
central area rounded not quadrangular; middle striae, 12-14 in $10 \mu, 18-20$ striae in $10 \mu$ near the poles; do not mistake for $\mathrm{N}$. pupula. X 1000.

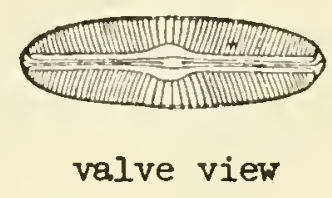

Notes :

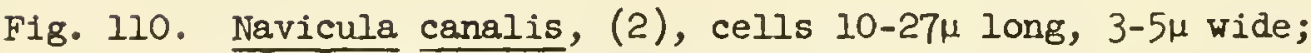
16-18 striae in 104. X 1000 .

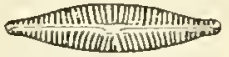

$$
\begin{aligned}
& \text { valve view }
\end{aligned}
$$

Notes:

Fig. 1ll. Navicula confervacea, (4), cells $10-28 \mu$ long, 5-8 $\mu$ wide;

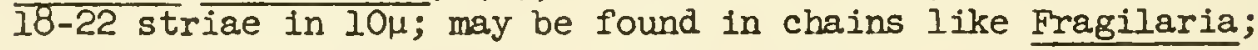
raphe can be seen in girdle view. X 1000.
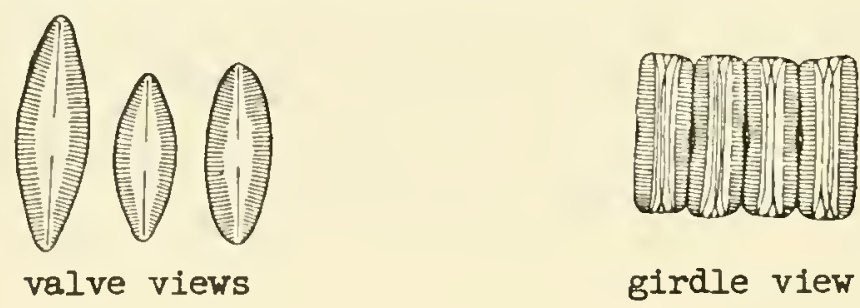

Notes: 


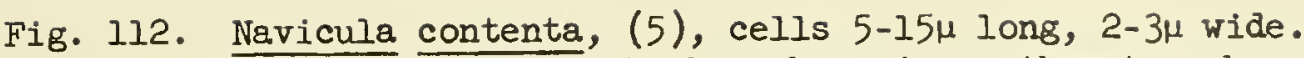
X 1500. May reach high numbers in southeastern brackishwater stations.

$$
\text { valve views }
$$

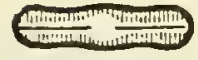

N. contenta

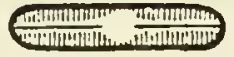

form parallela form biceps

Notes :

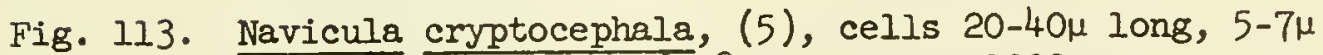
wide; striae fine, $16-18$ in $10 \mu . \times 1000$.

valve views

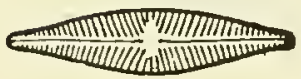

N. cryptocephala

var. veneta

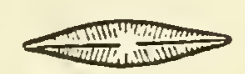

var. intermedia

Notes: 


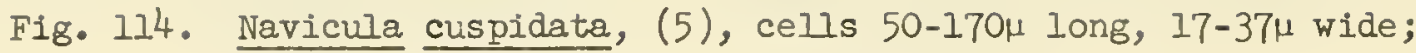
striae fine, $11-19$ in $10 \mu . \times 1000$.

valve views

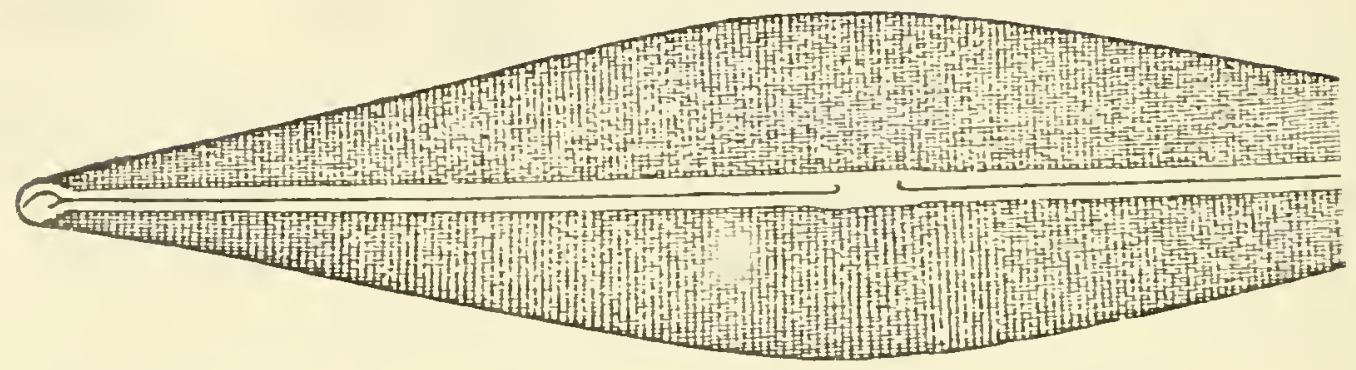

N. cuspidata

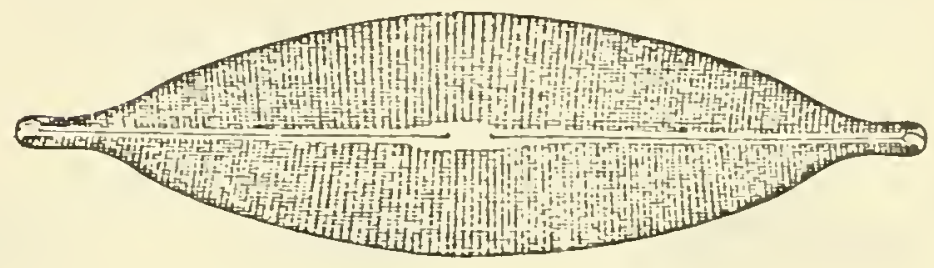

var. ambigua

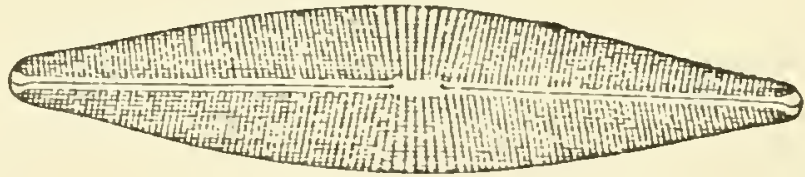

Notes:

var. Heribaudi

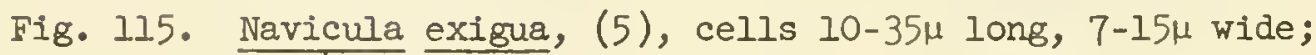
12-14 striae in 10\%. X 1000.

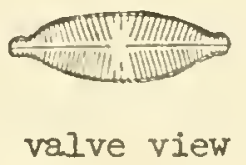

Notes : 


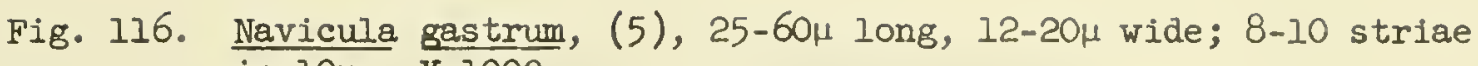
in $10 \mu . \times 1000$.

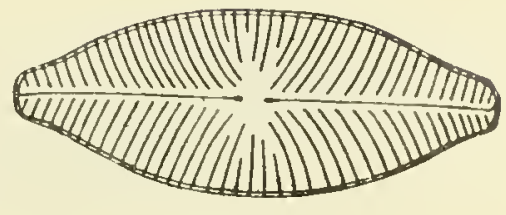

valve view

Notes:

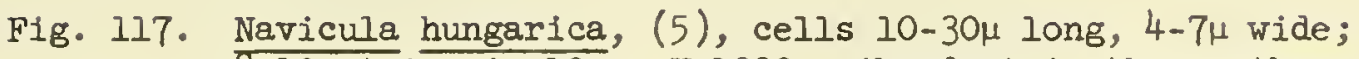

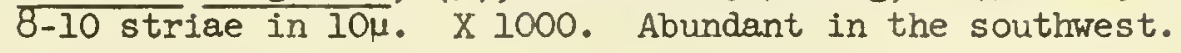
valve views

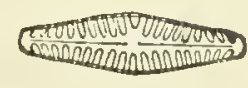

N. hungarica

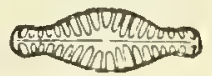

var. capitata

Notes: 


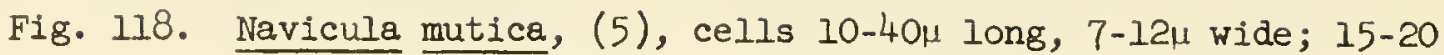
striae in 10\%; single eccentric puncta in the central area. $\mathrm{X} 1500$.

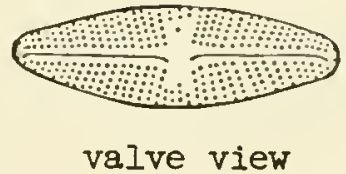

Notes :

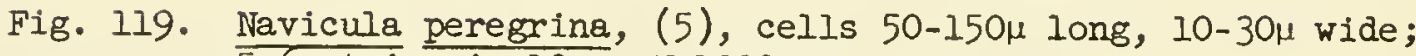
$5-6$ striae in $10 \mu . \times 1000$.

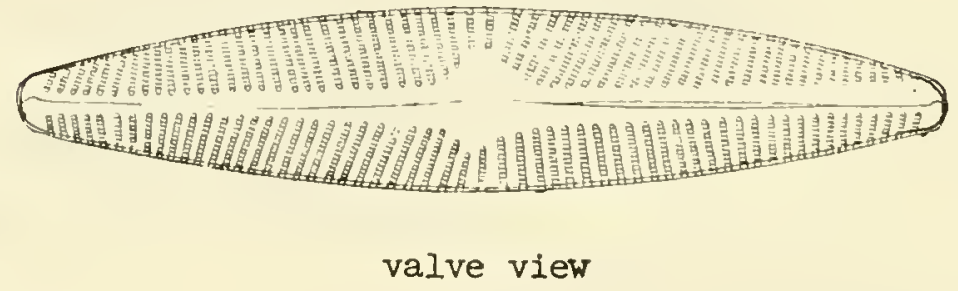

Notes :

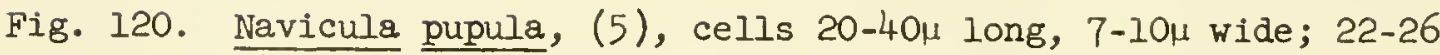
striae in $10 \mu$; no striae at the poles; central area quadrangular; can mistake for N. bacillum. X 1000 .

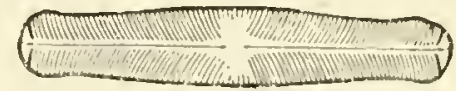

valve view

Notes:

var. capitata 
Fig. 121. Navicula pygmaea, (5), cells $10-45 \mu$ long, $8-24 \mu$ wide; about 26 striae in $10 \mu$. X 1000.

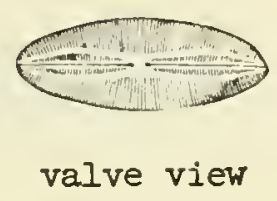

Notes :

Fig. 122. Navicula radiosa, (5), cells 40-120 $\mu$ long, 8-20 $\mu$ wide; 1012 striae in $10 \mu$. X 1000 .

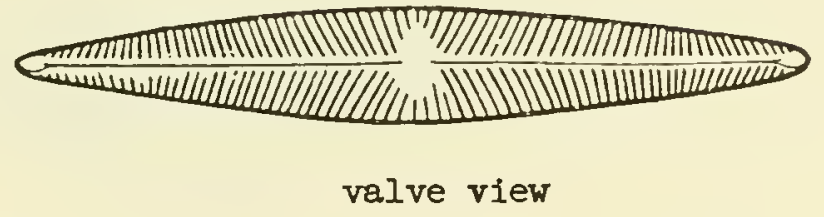

Notes:

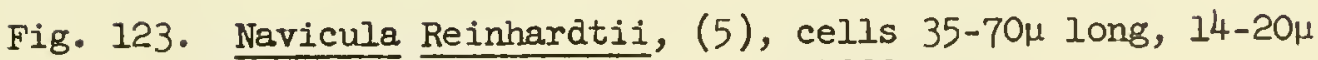
wide; 7-9 striae in $10 \mu . \times 1000$.

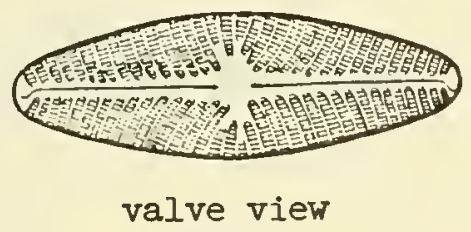

Notes : 


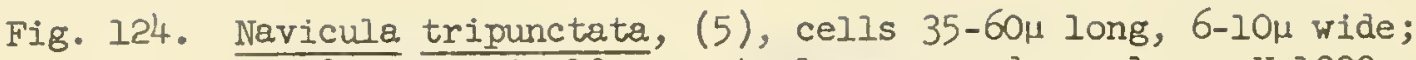

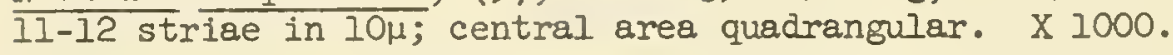

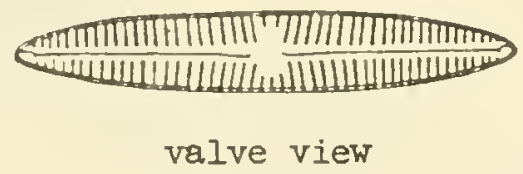

Notes :

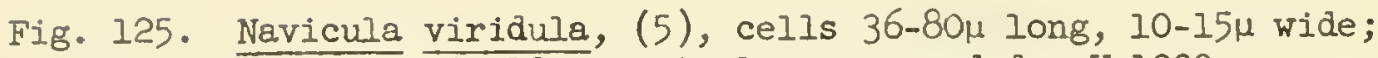

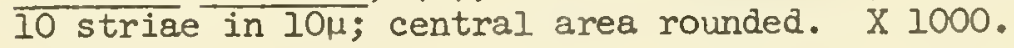

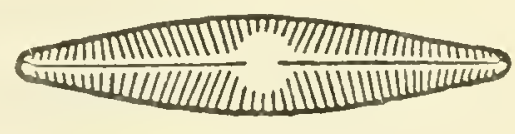

$$
\text { valve view }
$$

Notes:

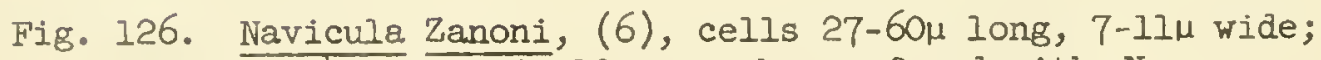

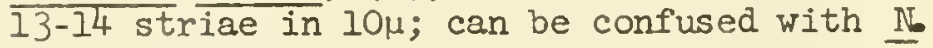
cryptocephala.

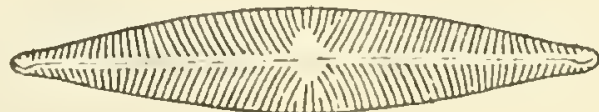

valve view

$\mathrm{X} 1000$

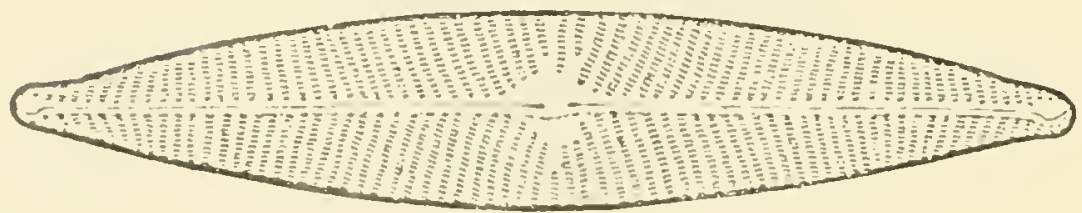

valve view

$\mathrm{X} 2000$

Notes: 
Notes on other species of NAVICULA. 
35a Keel elevated into a lateral "wing" or flattened on the

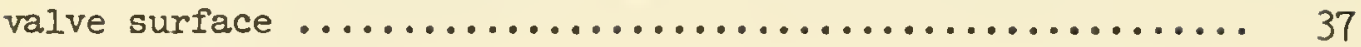

35b Keel elevated into an axial "wing" extending along the central axis of the valve......................... 36

36a Keel sigmoid, usually seen in girdle view (hour-glass-shaped), frustule twisted along the longitudinal axis; girdle broad with many longitudinal folds - AMPHIPRORA

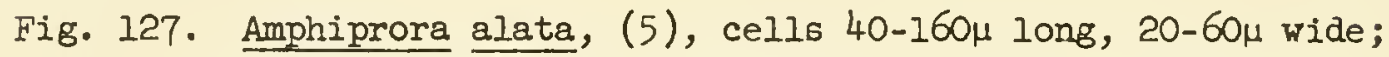
striae fine,prmctae discernable. X 1000. Abundant in the southwest.

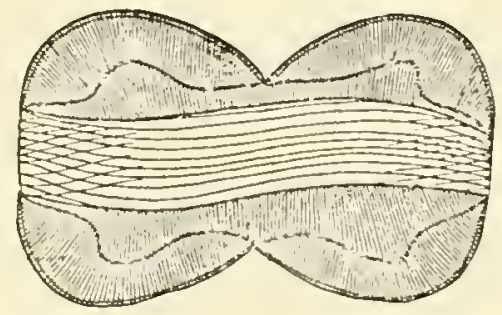

girdle view

Notes:

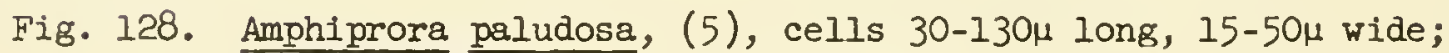
striae fine, punctae not discernable. X 1000. Abundant in the southwest.

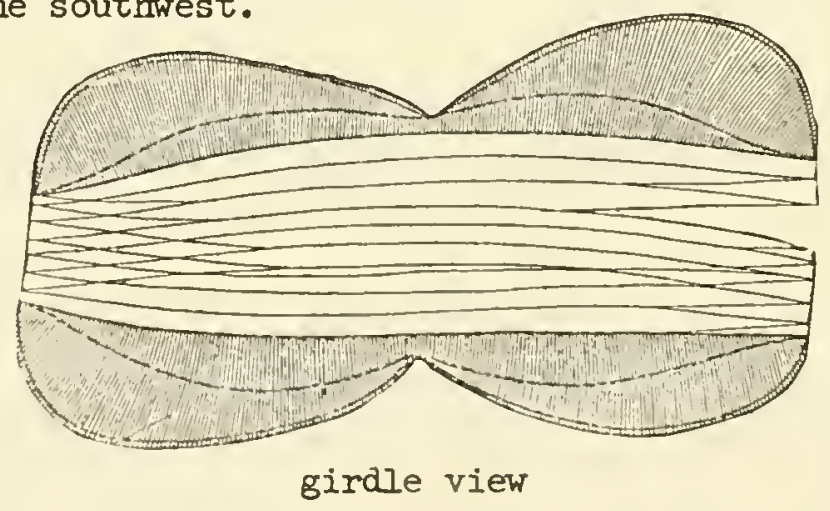

Notes: 


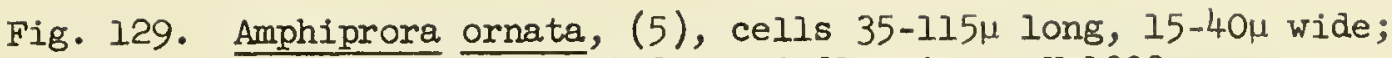
appears to be twisted in girdle view. X 1000.

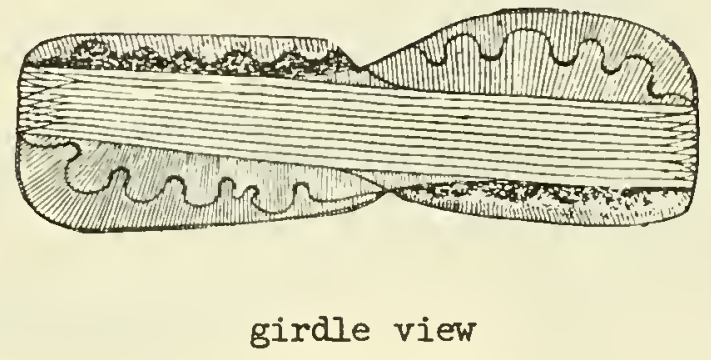

Notes :

Notes on other species of AMPHIPRORA 
36b Keel not sigmoid, girdle simple, not folded, keel eccentric TROPIDONEIS

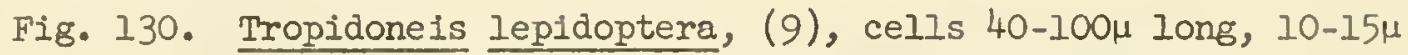
wide; girdle view easily confused with Amphiprora sp. $\mathrm{X} 2000$.
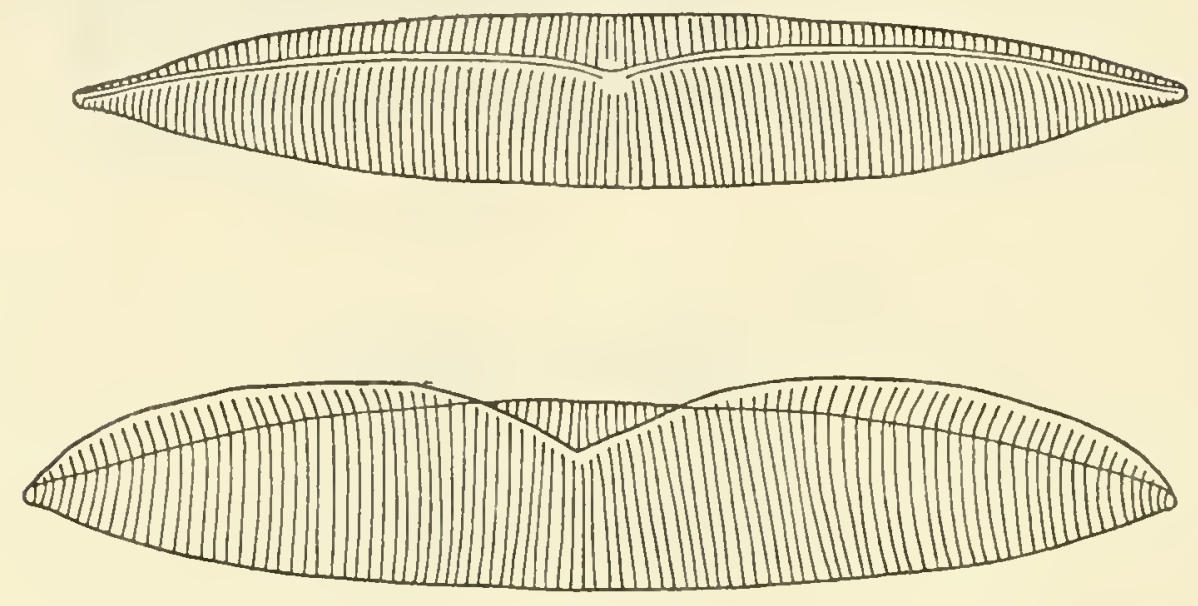

valve views

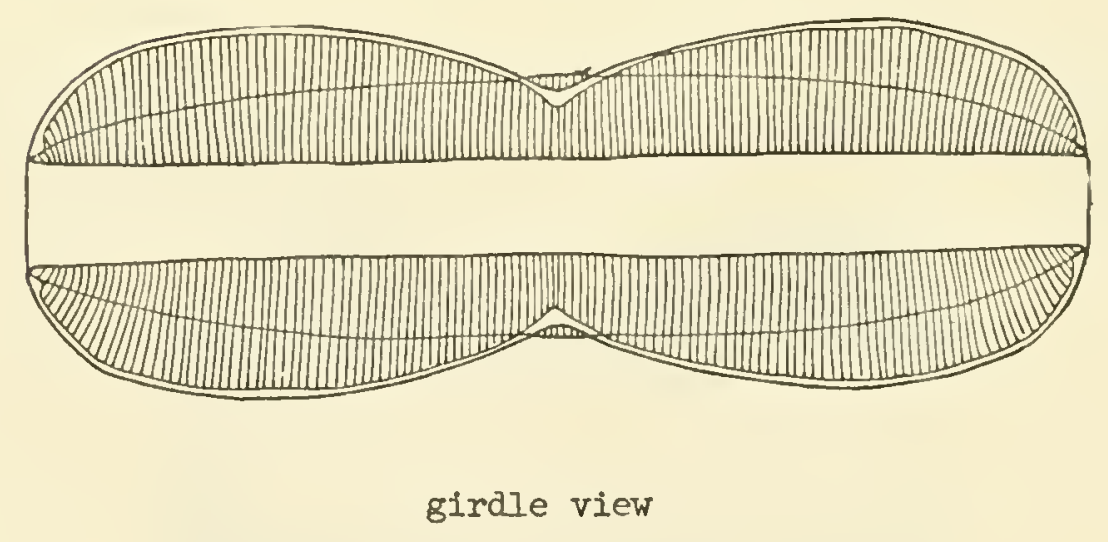

Notes : 
37a Valves with numerous internal transverse ribs extending completely across the valve........................ 38

370 valves without internal transverse ribs............... 40

38a Raphe and axial area with "V"-shaped medial extension; with transverse septae appearing as costae and alternating with two or more rows of punctae - EPITHEMIA

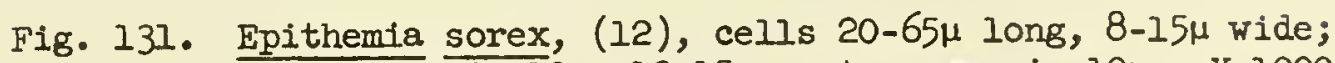

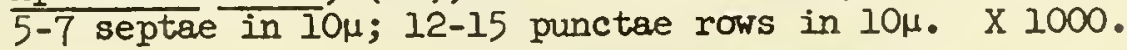

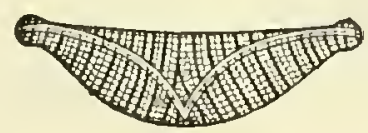

valve view

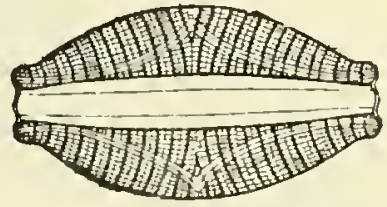

girdle view

Notes :

Fig. 132. Epithemia turgida, (12), cells 60-220 $\mu$ long, 15-18 $\mu$ wide;

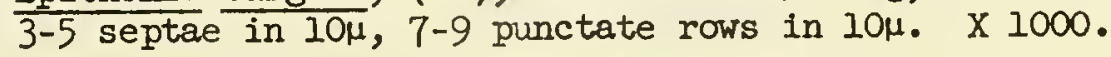

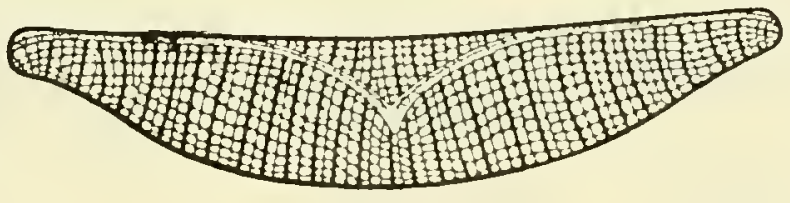

valve view

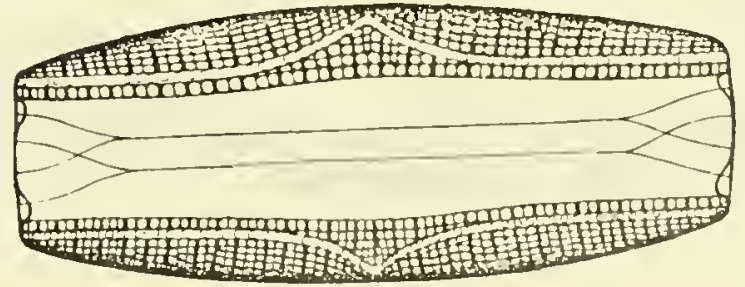

girdle view

Notes: 
84

Notes on other species of EPTTHEMIA.

38b Raphe and axial area without a "V"-shaped medial

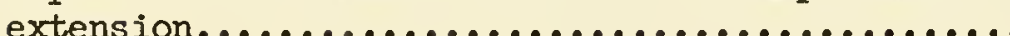

39a Raphe canal with pores, valves symmetrical to longitudinal axis - DENTICULA

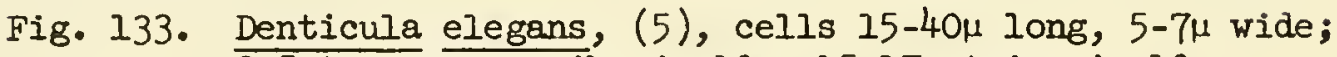
3-5 transverse ribs in $10 \mu ; 15-17$ striae in $10 \mu$.

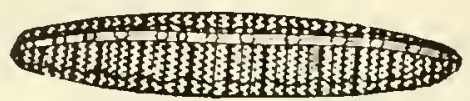

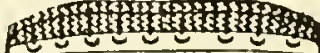

valve view

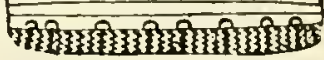

girdle view

Notes:

39b Raphe canal without pores, valves asymetrical to the longltudinal axis - RHOPALODIA 


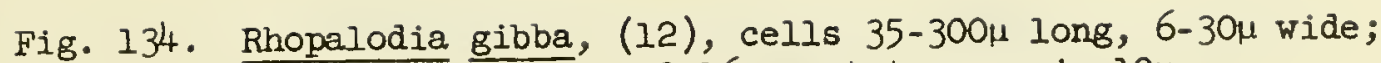
$6-8$ costae in 10 $;$; $12-16$ punctate rows in $10 \mu$.
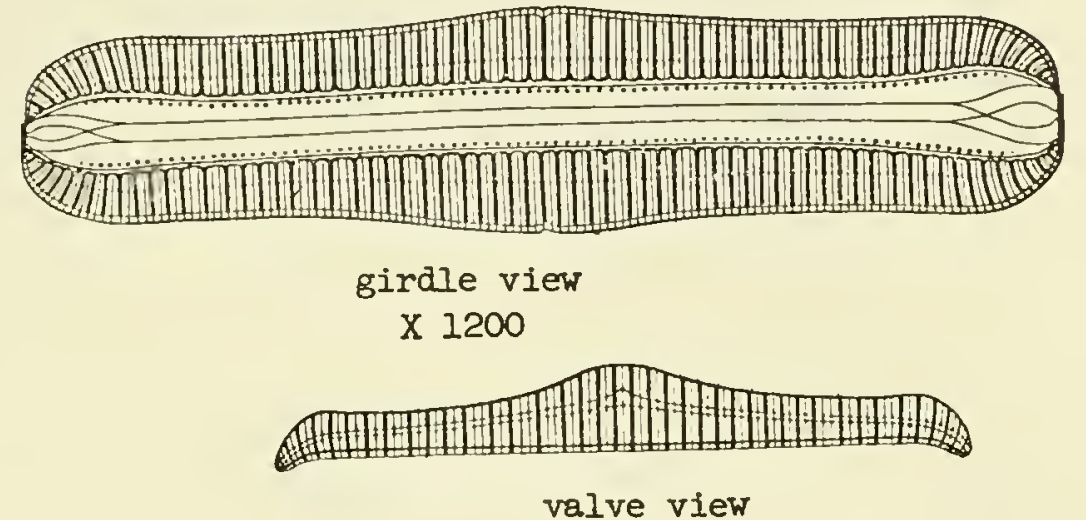

X 750

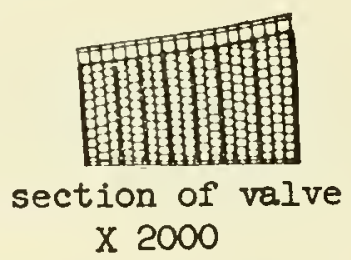

Notes :

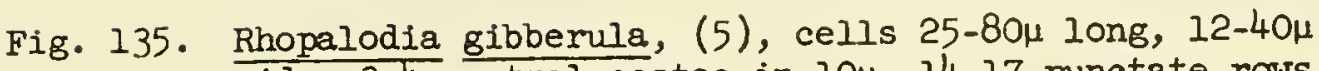
wide; 3-4 ventral costae in 101, 14-17 punctate rows in $10 \mu . \times 1000$.
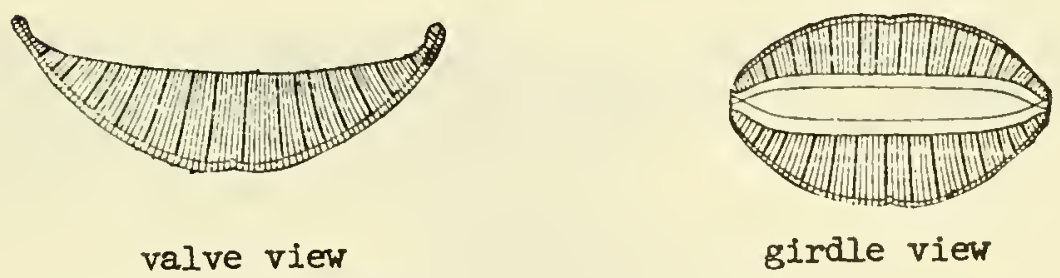

var. van Heurckii Notes: 
Notes on other species of RHOPALODIA.

40a Valves with lateral keel extending along both margins of each valve..................................... 41

$40 \mathrm{~b}$ Valves with lateral keel extending along one margin of each valve.................................. 42

4la Valve face longitudinally undulate, undulations conspicuous in girdle view; with broad, short, peripheral costae; longitudinal pseudoraphe present - CYMATOPLEURA

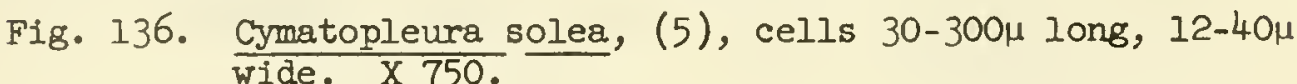

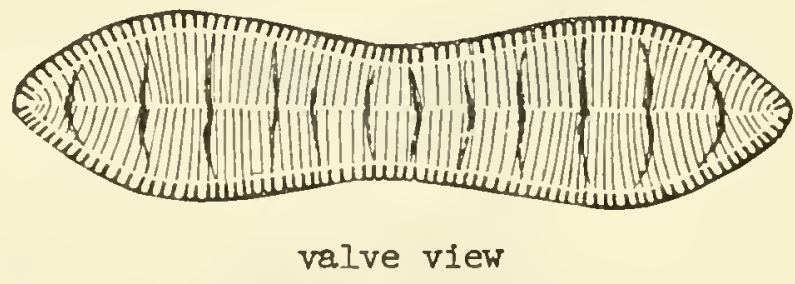

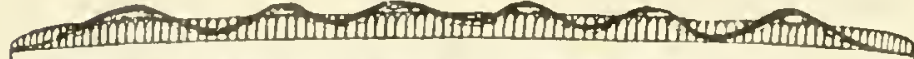

प्रा

girdle view

Notes : 
4lb Valve face not longitudinally undulate; valve face with longitudinal folds which appear as heavy costae, folds not conspicuous in girdle view; girdle view rectangular, naviculoid, wedge-shaped, or sigmoid; valve view linear, elliptical, ovate, or spirally twisted - SURIRELLA

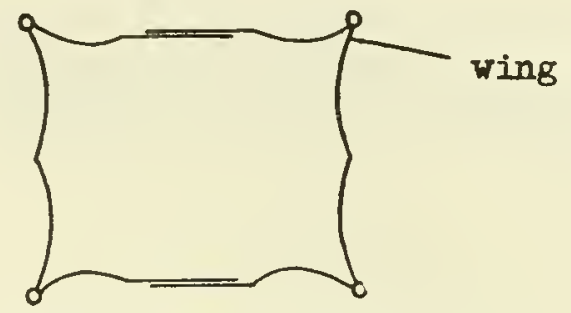

Diagrammatic cross-section of Surirella, (7)

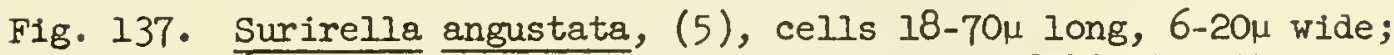
6-9 longitudinal folds in $10 \mu$; striae delicate, the only "common" Surirella that is transversely symetrical. $\mathrm{X} 1000$.

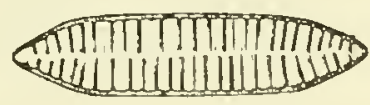

valve view

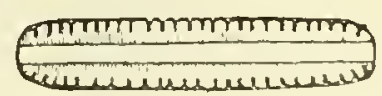

girdle view

Notes :

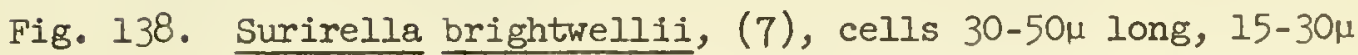
wide; longitudinal folds not extended to the center; border rajsed. X 1000. In Arkansas and Colorado Rivers.

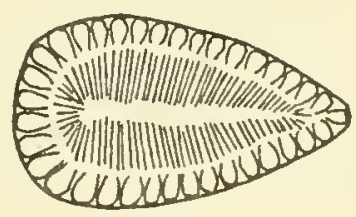

valve view

Notes : 


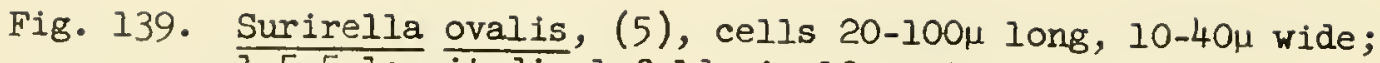

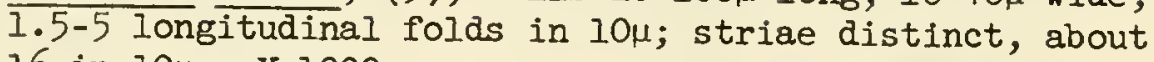
16 in $10 \mu$. X 1000 .

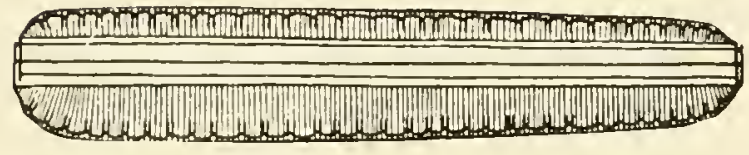

valve view

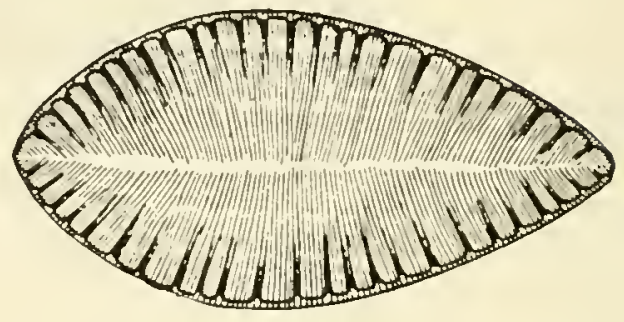

girdle view

Notes :

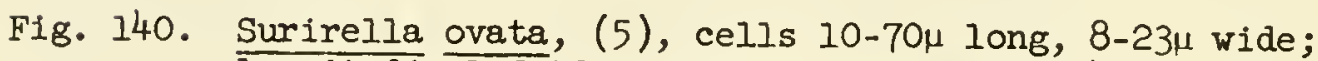

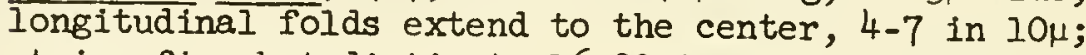
striae fine but distinct, $16-20$ in $10 \mu$. X 1000. Common in the southwest.
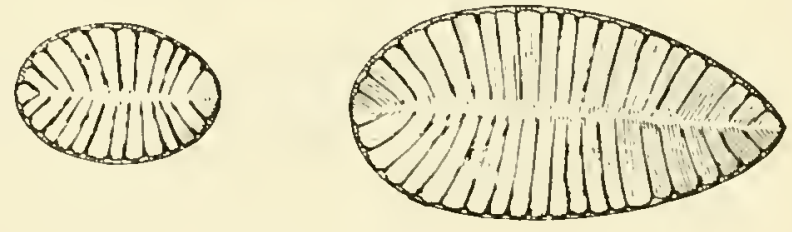

valve views

Notes : 


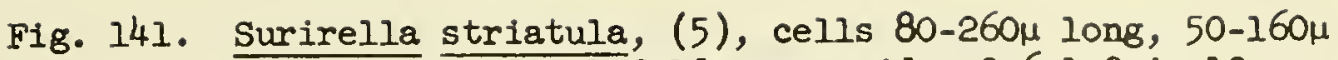
wide; longitudinal folds very wide, $0.6-1.2$ in $10 \mu$; small distinct protruberances on the outer edge of the longitudinal folds. X 400 .

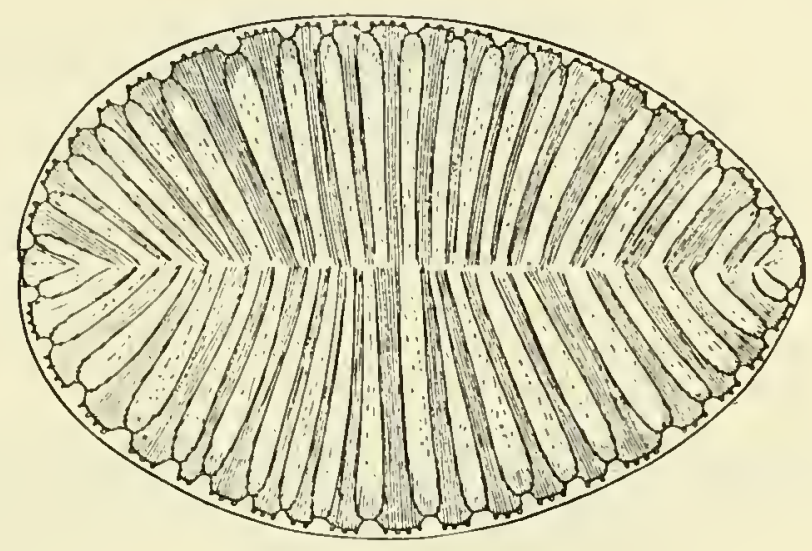

valve view

Notes :

42a Keels eccentric to the median axis, diagonally opposite;frustules rhombic in cross section, transversely striate, punctate or lacking ornamentation; a row of circular pores ("carinal dots") developed within the keel; frustules usually solitary but occasionally forming irregular ribbon-like chains or stellate colonies NITZSCHIA

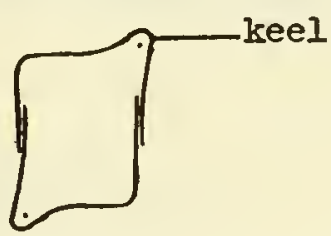

Diagrammatic cross-section of Nitzschia, 


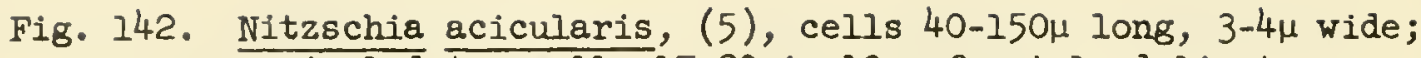
carinal dots small, $17-20$ in $10 \mu$; frustule delicate. $\mathrm{X} 1000$.

valve view

Notes:

Fig. 143. Nitzschia amphibia, (5), cells $12-50 \mu$ long, 3-5 $\mu$ wide;

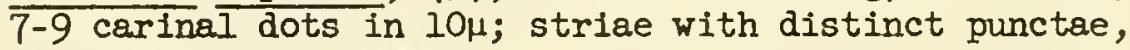
$15-19$ in $10 \mu$. $X 1000$.

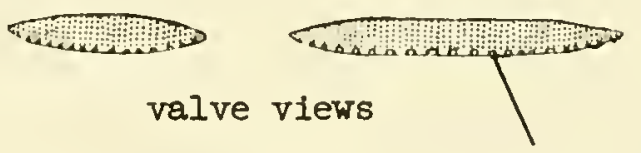

Notes:

carinal dot

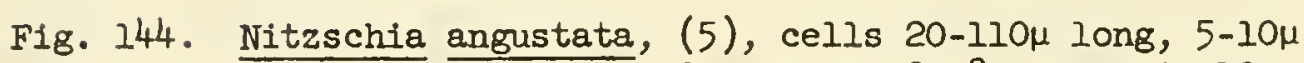
wide; carinal dots indistinct; $12-18$ striae in $10 \mu$. $\mathrm{X} 1000$.

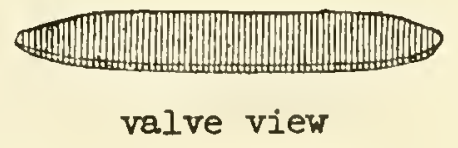

Notes : 


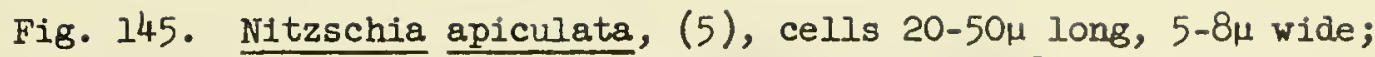
differs from $\mathrm{N}$. hungarica by having indistinct carinal

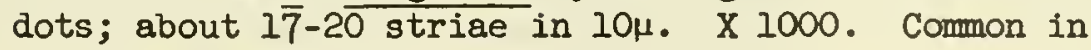
the Arkansas River.

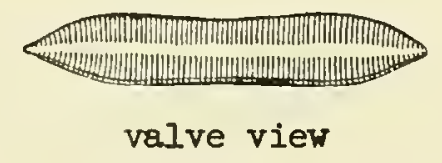

Notes :

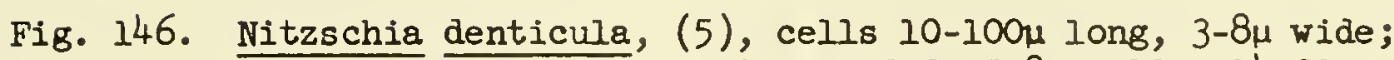
carinal dots rib-like and extended, 5-8 in 10 striae in $10 \mu . x 1000$. In southwest.

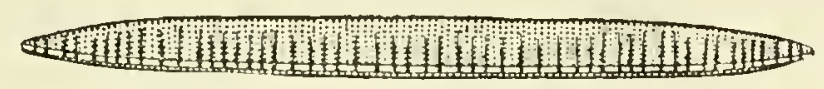

valve view

Notes :

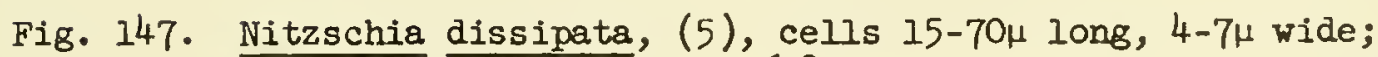
keel slightly eccentric, 6-8 carinal dots in 10 ; striae indistinct. $\mathrm{X} 1000$.

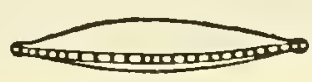

valve view

Notes: 


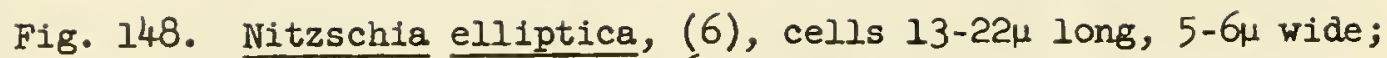
carinal dots small, $16-20$ in 10\%; striae indistinct; frusture delicate. X 1000. At times abundant in the Arkansas River.

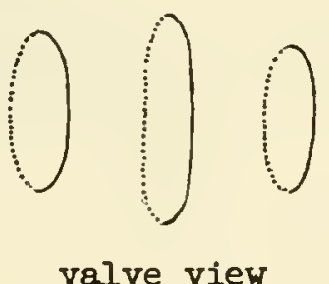

Notes :

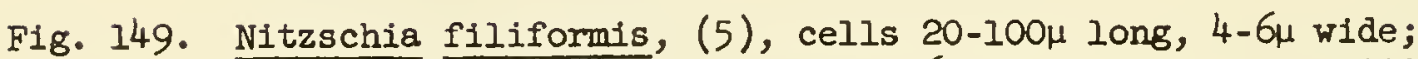

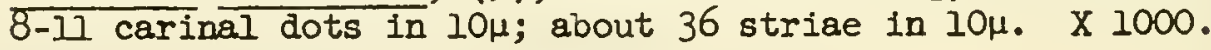

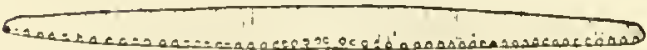

valve view

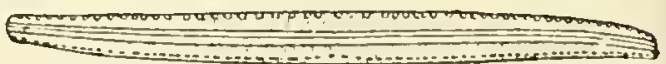

girdle view

Notes:

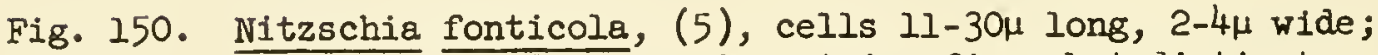

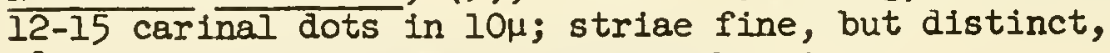

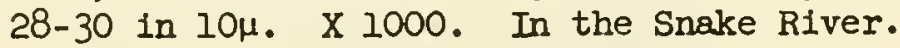

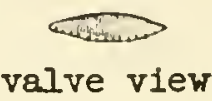

Notes : 
Fig. 151. Nitzschia holsatica, (5), cells $20-55 \mu$ long, $1.5-2 \mu$ wide; 14-17 carinal dots in $10 \mu$; striae fine; indistinguishable from other forms unless in the stellate colony. $\mathrm{X} 1000$. Common in the southwest.

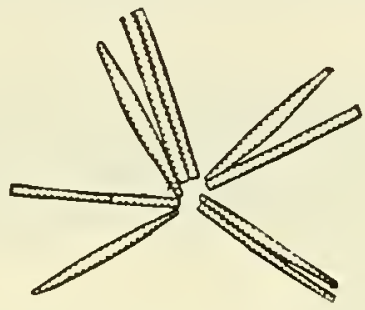

Colony

Notes :

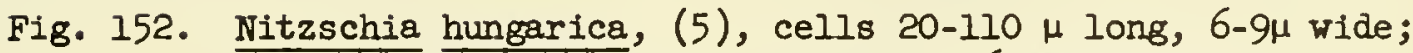
carinal dots distinct, $7-9$ in $10 \mu ; 16-20$ striae in $10 \mu$. $X 1000$. Abundant in the southwest.

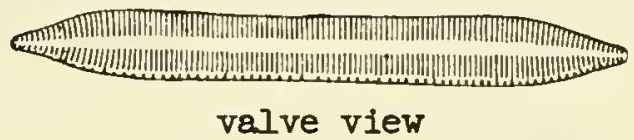

Notes :

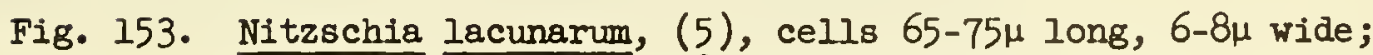
carinal dots small, $7-8$ in $10 \mu$; about 30 striae in $10 \mu$. $\mathrm{X} 1000$.

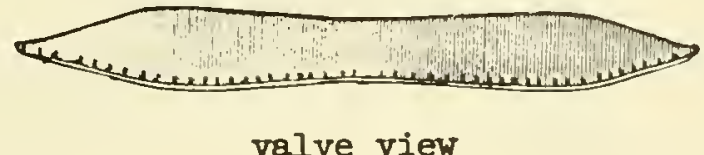

Notes 


\section{4}

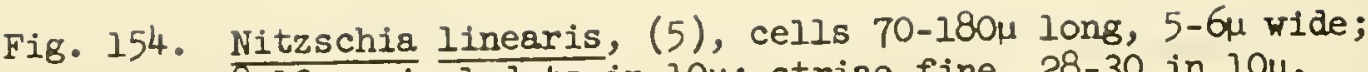
8-13 carinal dots in $10 \mu$; striae fine, 28-30 in $10 \mu$. $\mathrm{X}$ 1000. Common.

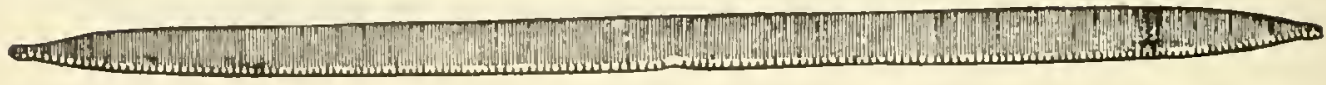

$$
\text { valve view }
$$

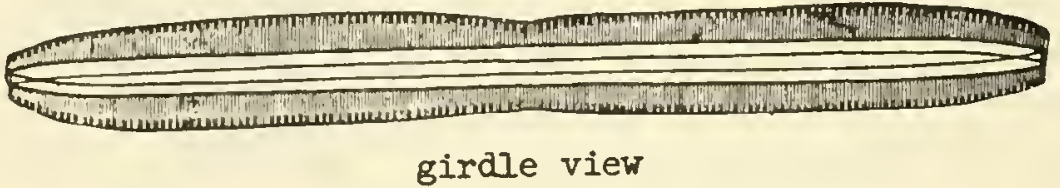

Notes:

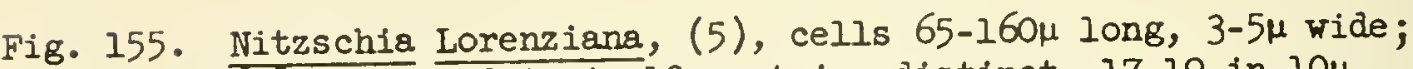
6-8 carinal dots in $10 \mu$; striae distinct, $17-19$ in $10 \mu$. $\mathrm{X} 1000$.

$$
\text { valve view }
$$

Notes :

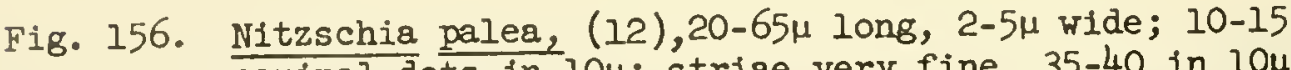
carinal dots in $10 \mu$; striae very fine, $35-40$ in $10 \mu$. $\mathrm{X}$ 1000. Widespread.

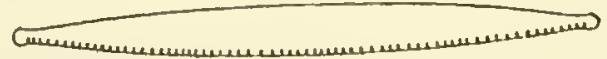

valve view

Notes: 


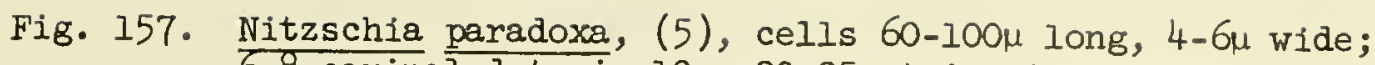
$6-8$ carinal dots in $10 \mu ; 20-25$ striae in $10 \mu$; do not confuse with $\mathrm{N}$. dissipata.

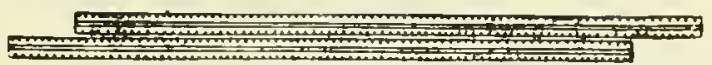

r.m.

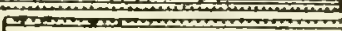

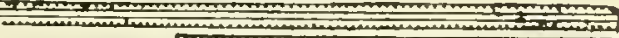

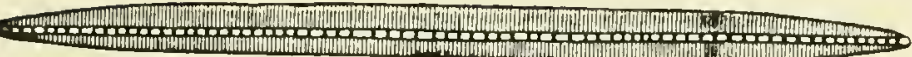

valve view

$\mathrm{X} 1000$

Notes:

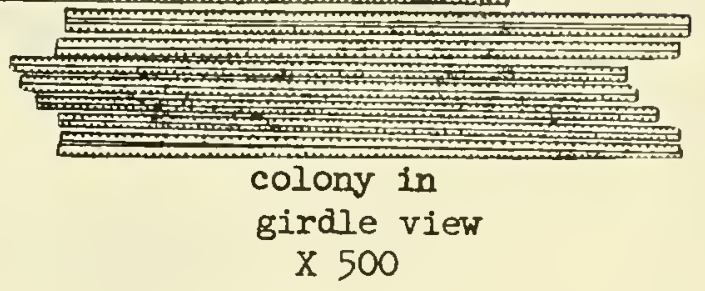

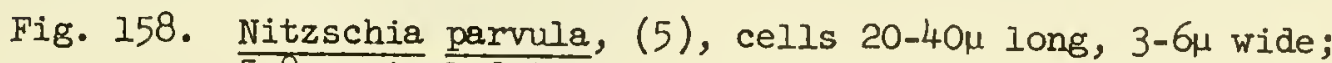
5-8 carinal dots in $10 \mu$; striae fine, $30-35$ in $10 \mu$. $\mathrm{X} 1000$.

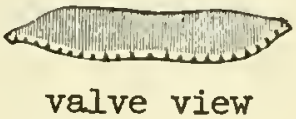

Notes : 
Fig. 159. Nitzschia sigma, (5), cells 50-70 $\mu$ long, 4-15 $\mu$ wide;

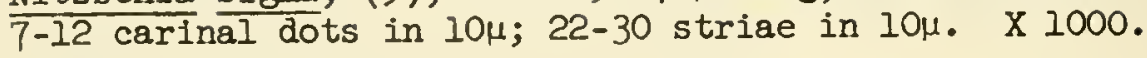

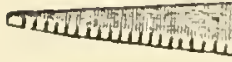

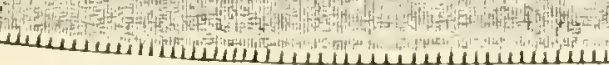

valve view

Notes:

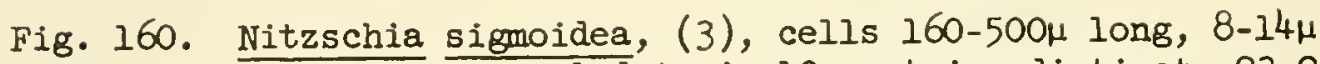
wide; 5-7 carinal dots in 104; striae distinct, 23-26 in $10 \mu$.

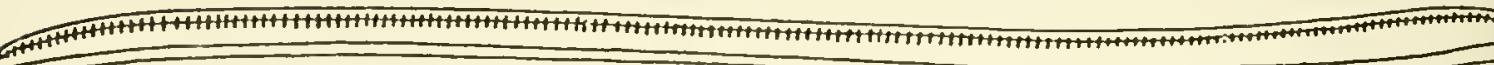

Селm

girdle view

X 500

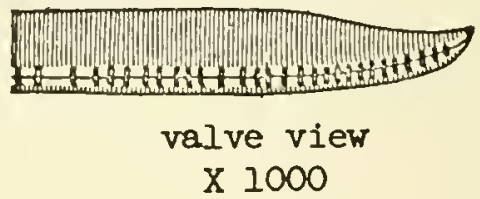

Notes :

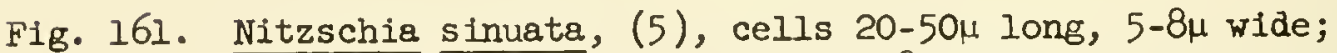
5-6 carinal dots in $10 \mu$; about 18 striae in $10 \mu . \times 1000$.

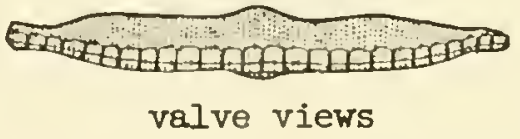

Notes : 


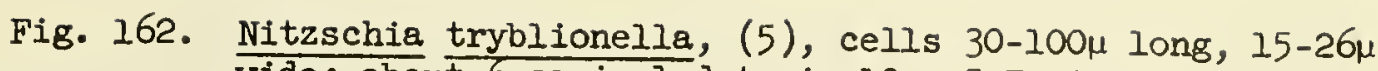
wide; about 6 carinal dots in $10 \mu ; 5-7$ ribs in $10 \mu$. X 1000 .

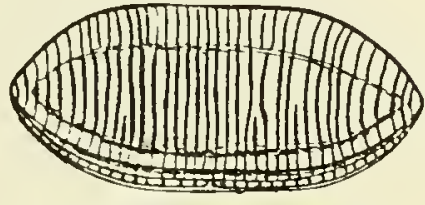

valve view

Notes:

var. victoriae

Notes on other species of NITZSCHIA 
42b Keels eccentric to the median axis, directly opposite;

frustules rectangular in cross section, transversely striate or punctate, capitate ends, medianly constructed - HANTZSCHIA

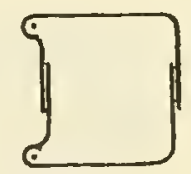

Diagramatic cross-section of Hantzschia, (7)

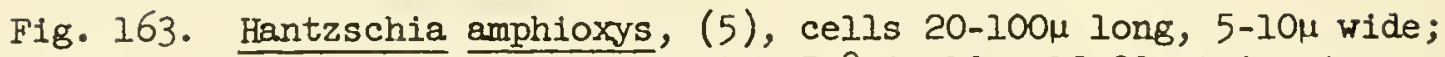
carinal dots not elongate, $5-8$ in $10 \mu ; 13-20$ striae in

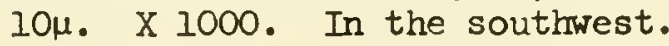

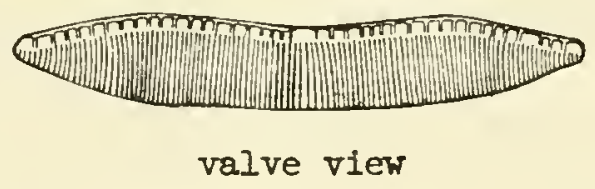

Notes :

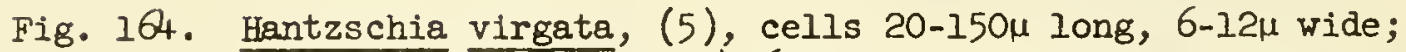
carinal dots elongate, $4-6$ in $10 \mu ; 9-15$ striae in $10 \mu$. $\mathrm{X} 1000$.

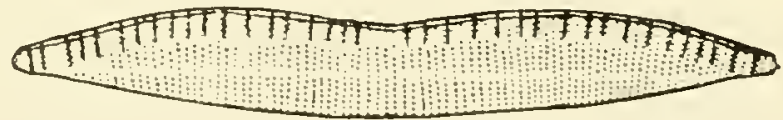

valve view

Notes: 

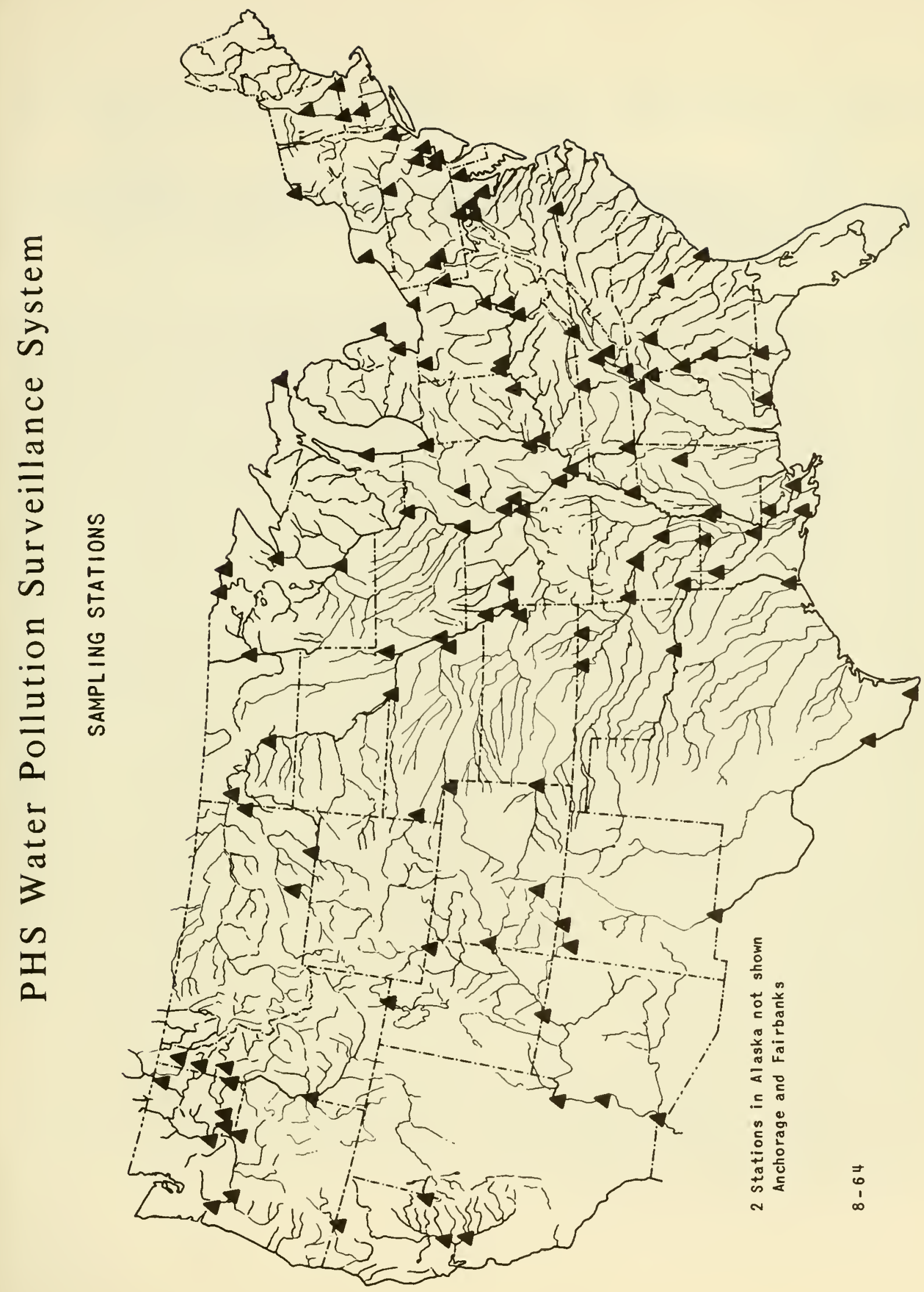

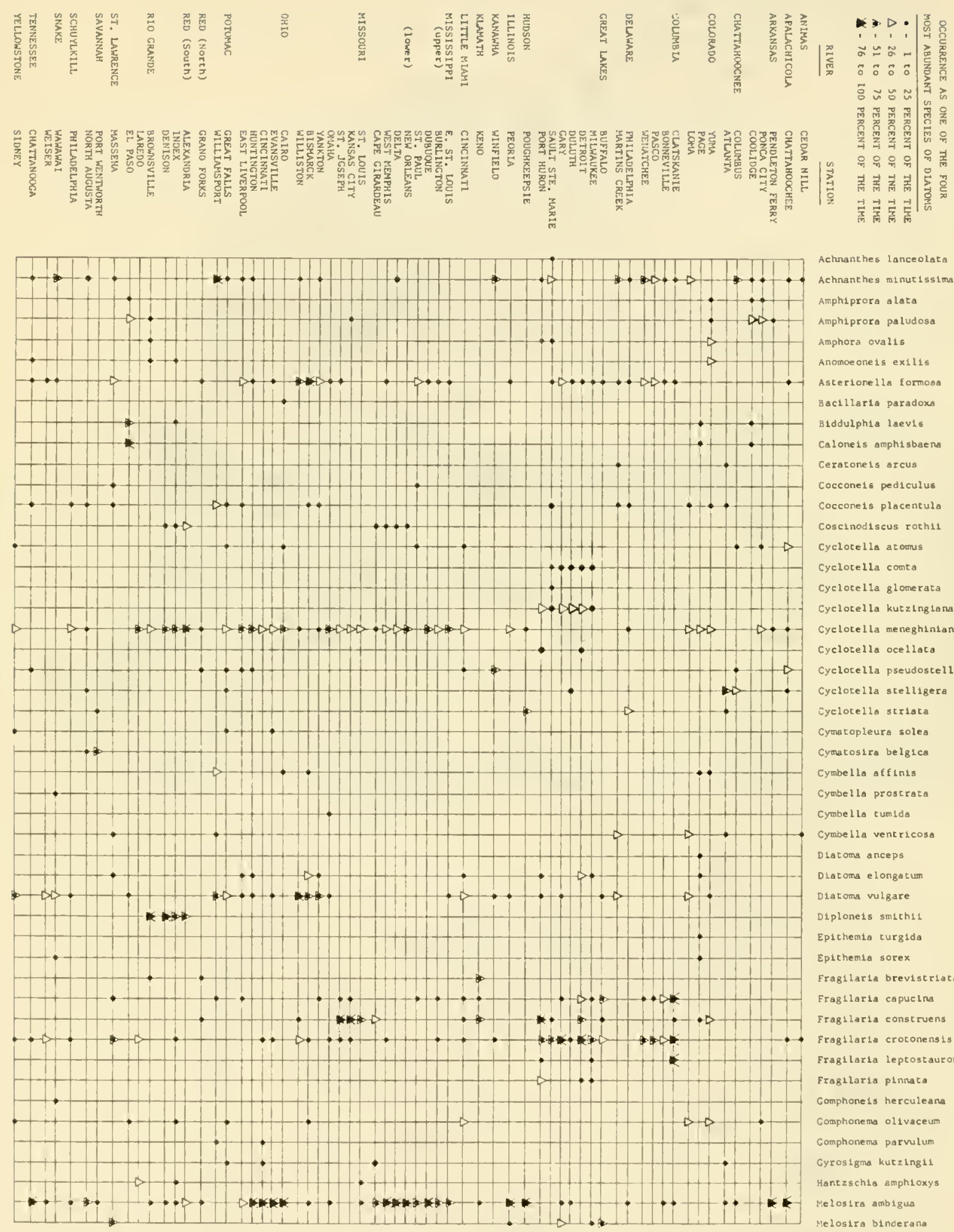

Acturanthes lanceolata Achnanthes minutissima Amphiprora alaca Amphiprora paludosa Amphora oval1s Anomoeone 15 exil1s Asterionelis formosa Bacillaria paradoxa Blodulphia laevia calone1s amphisbaena Ceratone 1 s arcus Coccone1: pediculus coccone1s placentula Coscinodiscus rothil Cyclotella atocrus cyclotella conta Cyclotella glomerata Cyclotella kutzinglana Cyclocella meneghinians Cyclotella ocellata Cyclotella pseudostelligera Cyclocella scelligera Eyclotella striata Cymatopleura solea cymatosira belgica Cymbella atfinis Cymbella prostrata Cymbella tumida Cymbella ventricosa DLatoma anceps Diacoma elongatum Dlacoma vilgare Diplonels smithil Epithemia turgida Eplthemla sorex Fragilarla brevistriata Fragllarla capuelna Fragilarta construens

Fragilarla crotonens ds Fragilarla leptoseauron Fragilarta plnnaca Comphone 1: herculean Gomphonema olivaceum Gomphonema parvulum Cyzosign kutzlngll Hantzschis amphloxys Melosira ambigua Melosira binderana 


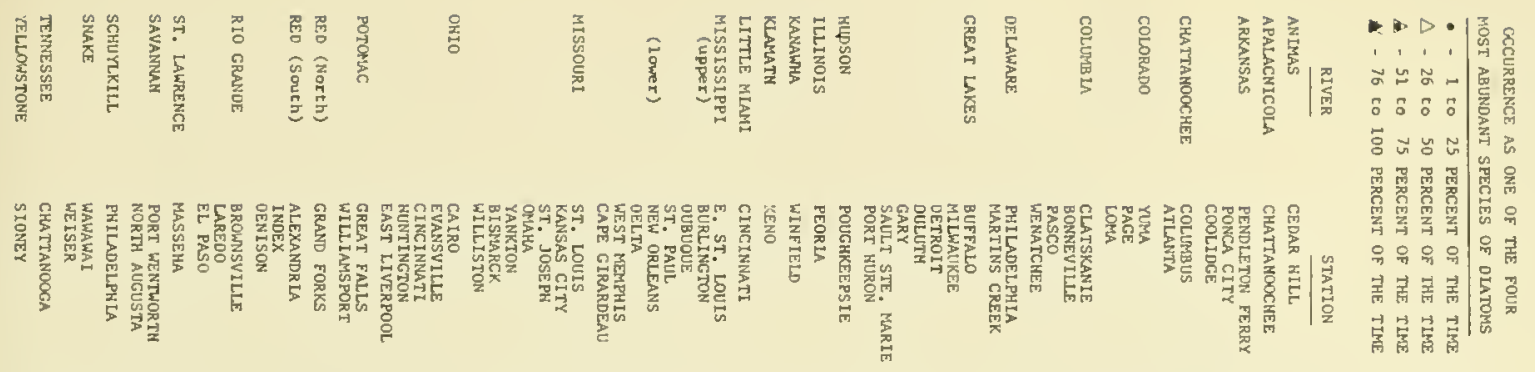

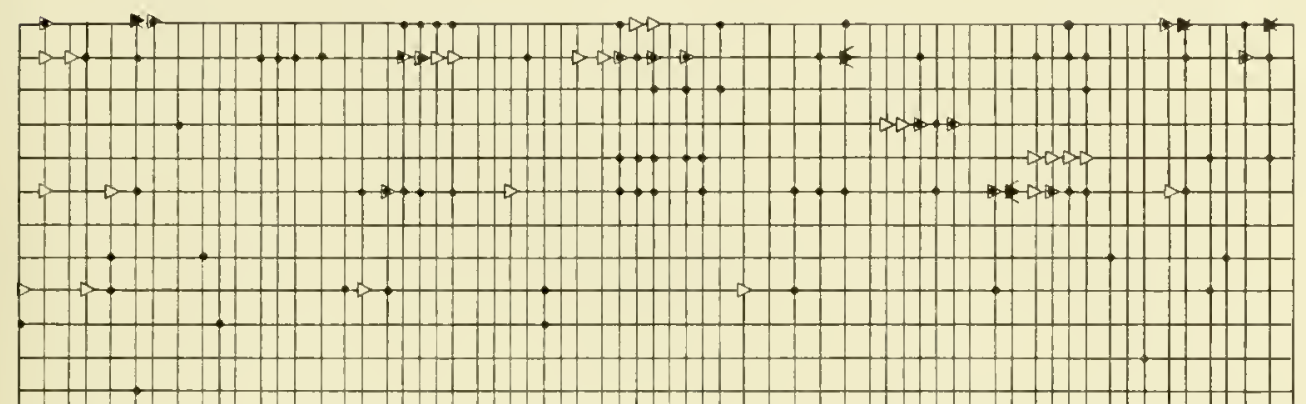

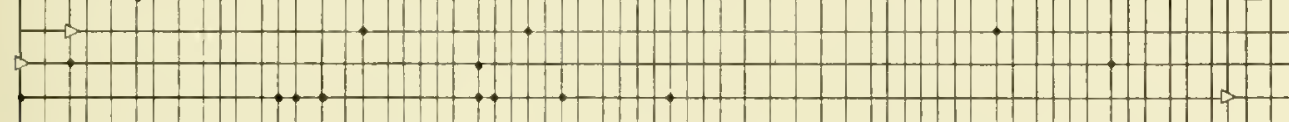

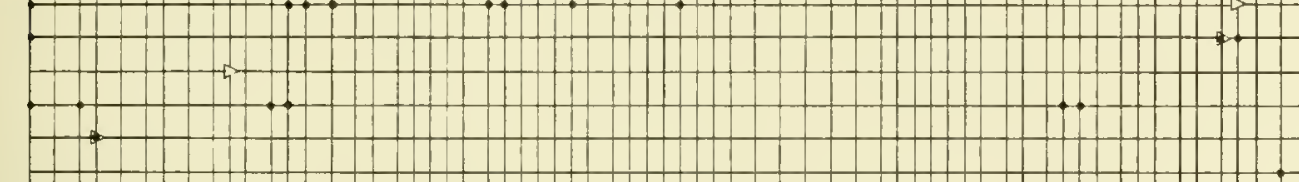

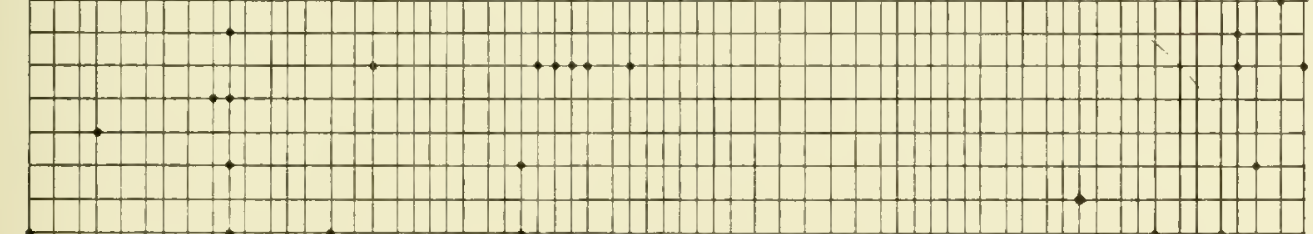

Melosira diatans alpigena

Melosira granulata
M. granulata angustiasima

Meloaira 1slandiea

Melosita italica

Melosira varians

Meridion eirculare

Navicula carailis

Navicula cryptocephala

Navicula cuspidata

Navicula Incompoaite

Navicula notha

Navicula tripunctata

Navicula viridula

Nitzechla acicularis

N1tzschle apiculata

Nitzachia denticula

Nitzschia dissipata

Niezschia fonticola

Nitzschia holastica

N2tzachla hungarica

N1tzschia linearis

Nitzschia aignoldea

Nitzschia tryblionel la

Pinnularta bores 1.

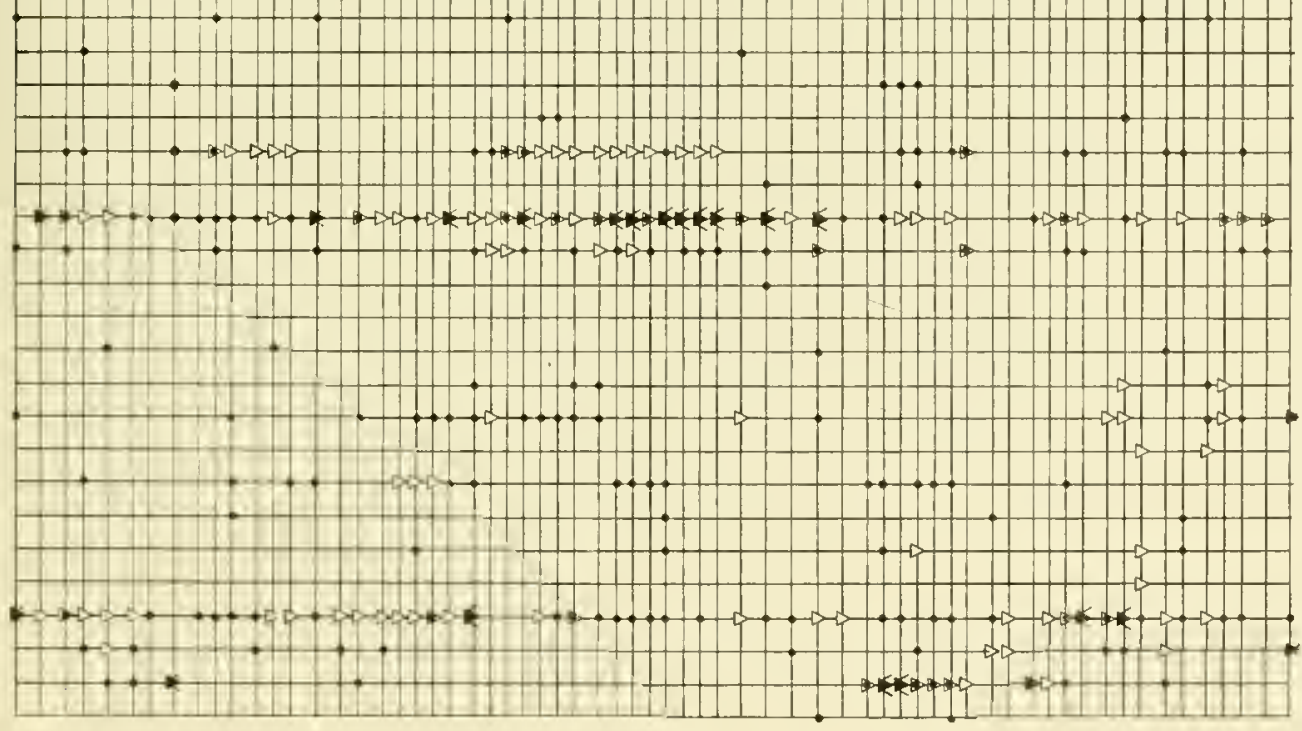

Pleuronigma delicatulura

Rhoicosphenia curvata

Rhizosolenis eriensis

Rhopslodia gibba

S. astraca minutula

Stephanodiacus dublus

Stephanodiscus hantzschia

Stephanodíscus niagarae

5. niagarae var. magnifiea

Stephanodiscus tenuls

Surirella angustata

Surirella brightwellit

jurirella ovata

surirella atriatula

synedra a eus

Syredra pulchelle

Synedra nana

Synedra tabulata

synedra wina

Symedra vaucheriae

Tabellaria fenestrata

Tabollarla tlocculosa 

